University of Louisville

ThinkIR: The University of Louisville's Institutional Repository

Electronic Theses and Dissertations

$5-2012$

\title{
Bawdy badges and the Black Death : late medieval apotropaic devices against the spread of the plague.
}

Lena Mackenzie Gimbel 1976-

University of Louisville

Follow this and additional works at: https://ir.library.louisville.edu/etd

\section{Recommended Citation}

Gimbel, Lena Mackenzie 1976-, "Bawdy badges and the Black Death : late medieval apotropaic devices against the spread of the plague." (2012). Electronic Theses and Dissertations. Paper 497. https://doi.org/10.18297/etd/497

This Master's Thesis is brought to you for free and open access by ThinkIR: The University of Louisville's Institutional Repository. It has been accepted for inclusion in Electronic Theses and Dissertations by an authorized administrator of ThinkIR: The University of Louisville's Institutional Repository. This title appears here courtesy of the author, who has retained all other copyrights. For more information, please contact thinkir@louisville.edu. 


\title{
BAWDY BADGES AND THE BLACK DEATH: LATE MEDIEVAL APOTROPAIC DEVICES AGAINST THE SPREAD OF THE PLAGUE
}

By

Lena Mackenzie Gimbel

B.A., University of Louisville, 2010

\author{
A Thesis \\ Submitted to the Faculty of the \\ College of Arts and Sciences \\ Of the University of Louisville \\ in Partial Fulfillment of the Requirements \\ for the Degree of
}

Master of Arts

\author{
Department of History \\ University of Louisville \\ Louisville, Kentucky
}

May 2012 


\section{BAWDY BADGES AND THE BLACK DEATH: LATE MEDIEVAL APOTROPAIC DEVICES AGAINST THE SPREAD OF THE PLAGUE}

\section{By}

Lena Mackenzie Gimbel

B.A., University of Louisville, 2010

A Thesis Approved on

April 11, 2012

by the following Thesis Committee:

Dr. Blake Beattie

Thesis Director

Dr. Genevieve Carlton

Dr. Pamela Beattie 


\title{
DEDICATION
}

This thesis is dedicated to my maternal Grandparents

\author{
Mr. Marvin Edward Keene \\ and
}

Mrs. Wanda Opal Keene

I know they would be proud. 


\section{ACKNOWLEDGMENTS}

I would first like to thank my Thesis Director, Dr. Blake Beattie, for his unending patience, guidance, and ability to make me see the humor in things. I would next like to thank my other committee members, Dr. Genevieve Carlton and Dr. Pamela Beattie, for their commitment and support. My thanks for my first mentor, Dr. Karen Britt, are without limit. Without her unending support and belief in my potential, I would not be where I am today. I would also like to thank Jack and Elizabeth Kerpestein for their generous help in navigating the tricky waters of the Dutch language. I want to express my deepest thanks to Wes, my best friend, soon to be husband, and partner in life, for his undying patience when the going got tough, which it did a lot. His support and loving shoulder allowed this thesis to come to fruition. Also, many thanks to all of my family, especially my mother, Cynthia Gimbel, who is the best editor a person could have. 


\section{ABSTRACT \\ BAWDY BADGES AND THE BLACK DEATH: LATE MEDIEVAL APOTROPAIC DEVICES AGAINST THE SPREAD OF THE PLAGUE

\author{
Lena Mackenzie Gimbel
}

April, 11, 2012

This thesis examines a large corpus of enigmatic pilgrimage badges dating from roughly $1350-1500 \mathrm{CE}$. The badges were brought to light during archaeological excavations of water sites throughout the Schelde Estuary in the Netherlands, the riverbanks of the Seine in France, and the Thames in England. A small selection of the iconography of the corpus includes: ambulant vulvas on stilts, winged and crowned pudenda pilgrims complete with pilgrims' staffs and rosaries, couples having sex, and ambulant winged phalli. The few scholars who have attempted their study have labeled the badges as erotic, obscene, rude, naughty, and pornographic. The advanced study of the tokens provides a contrasting interpretation. Ultimately, this thesis argues that the bawdy badges functioned as apotropaic, or protective devices, meant to safeguard their owners from the threat of the evil eye, which during the worst outbreaks of the Bubonic Plague, was thought capable of transmitting the disease. 


\section{TABLE OF CONTENTS}

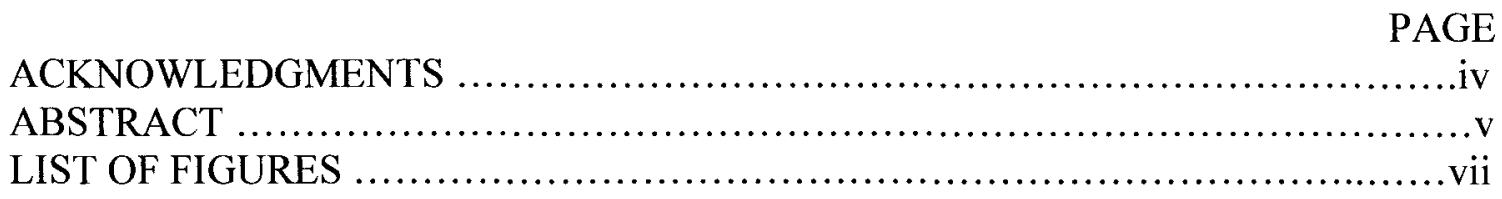

\section{CHAPTER}

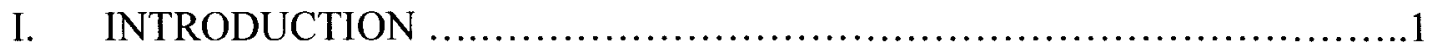

II. A HISTORIOGRAPHICAL ANALYSIS OF THE BAWDY BADGES ........9

III. THE PLAGUE \& THE PALLIATIVE MAGICO-MEDICAL RESPONSE ...24

IV. THE BAWDY BADGES: AN INDECENT FACE FOR THE CURE .........52

Examples from England .........................................59

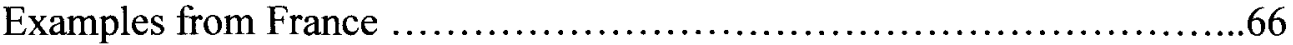

Examples from the Netherlands and the Low Countries ..................69

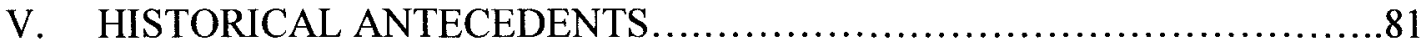

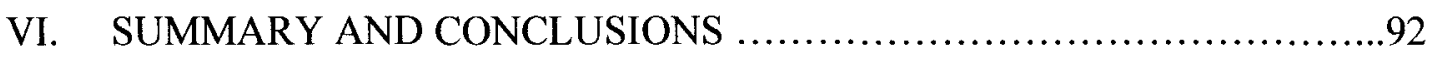

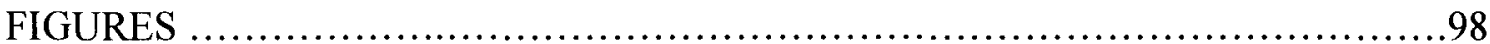

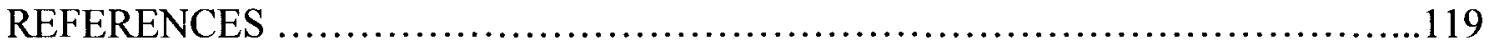

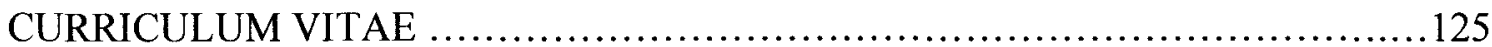




\section{LIST OF FIGURES}

FIGURE $\quad$ PAGE

Table 1. Location of excavated badges in the Netherlands and Low Countries .......70-71

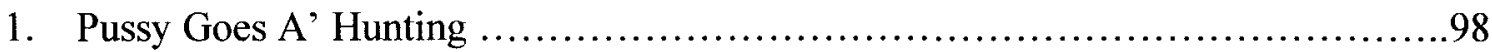

2. Ambulant pudendum turning penis on a roasting spit ..........................98

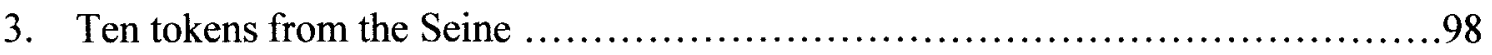

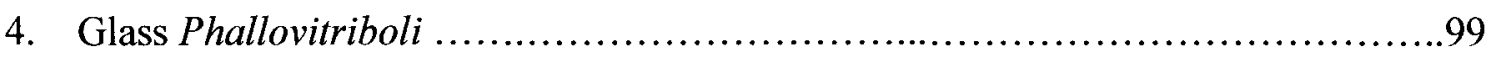

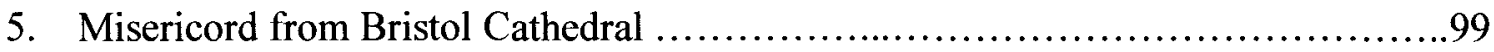

6. Ambulant phalli carrying crowned vulva on a processional bier ..................100

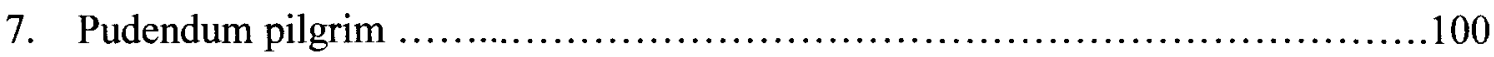

8. Ambulant pudendum walking on stilts wearing a phallus crown ..................100

9. Penises manning sailing vessels ............................................. 101

10. Ambulant phallus wearing a bell and crown .................................. 101

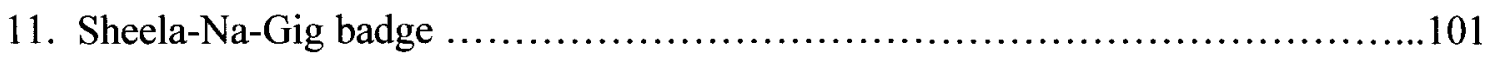

12. Pudendum turning penis on a roasting spit ...................................101

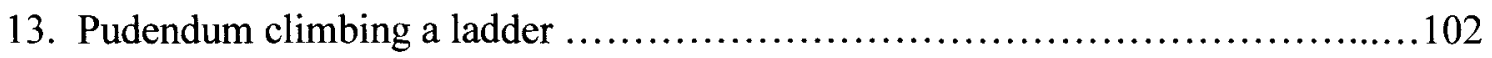

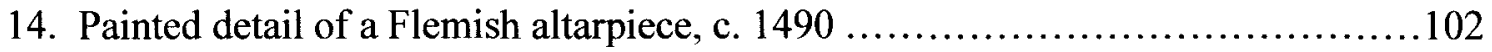

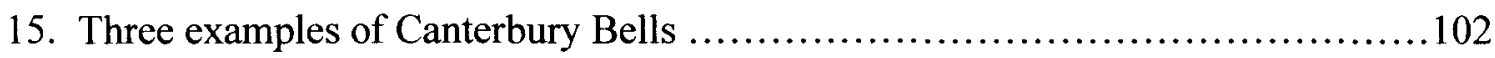

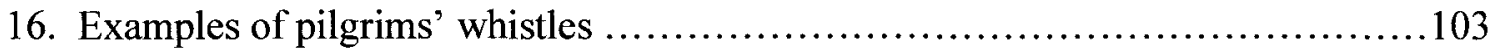

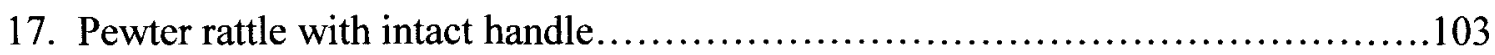

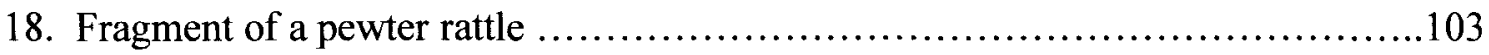


19. Reconstruction drawing of a pewter rattle

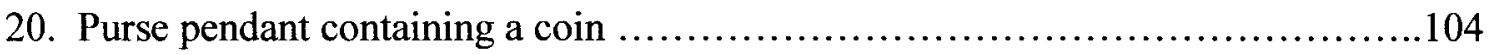

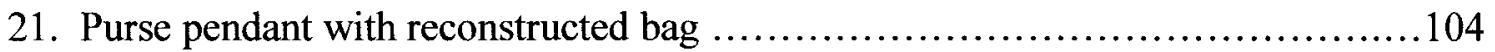

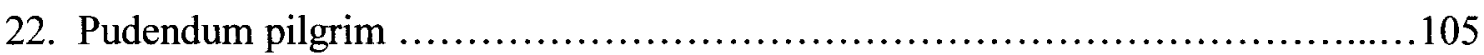

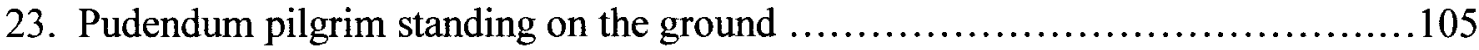

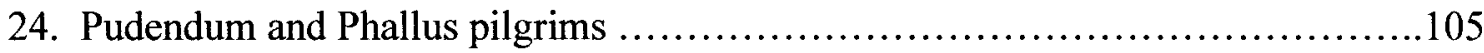

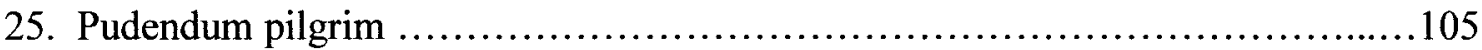

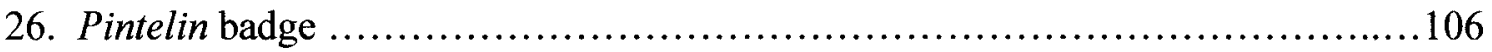

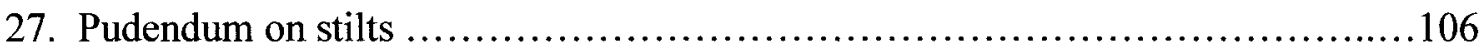

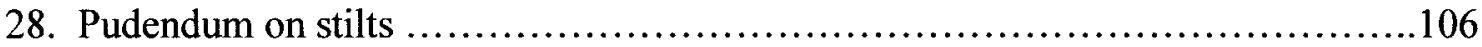

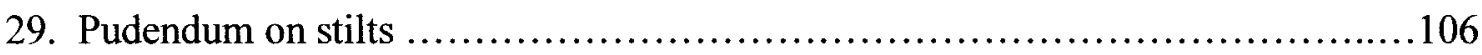

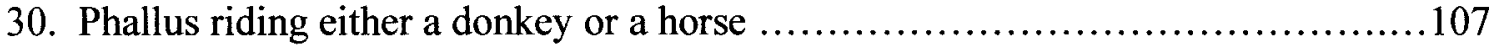

31. A second 'Pussy Goes A' Hunting' .............................................. 107

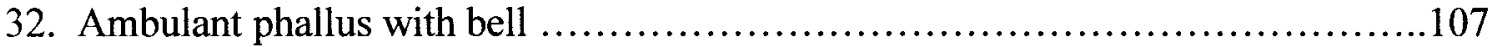

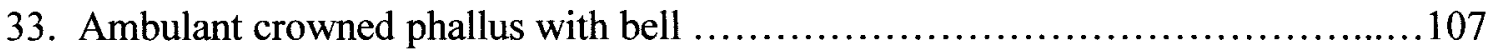

34. Ambulant crowned phallus with bell ........................................108

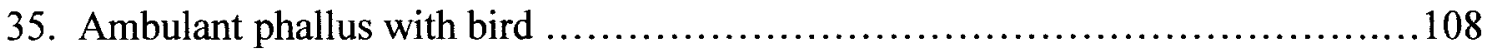

36. Ambulant phallus standing on a vulva ..................................... 108

37. Ambulant phallus standing on a vulva .................................... 108

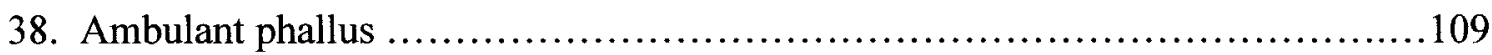

39. Couple having sex while a man and dog watch ...............................109

40. Couple having sex while a man and dog watch ..............................109

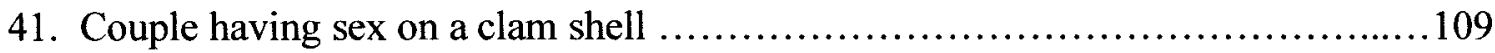


42. Clam shell pendant/locket with an interior vulva

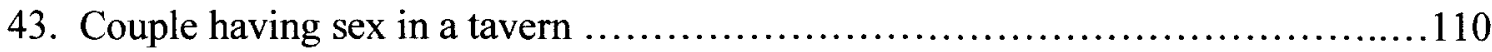

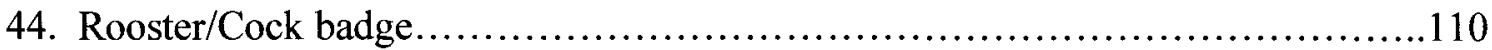

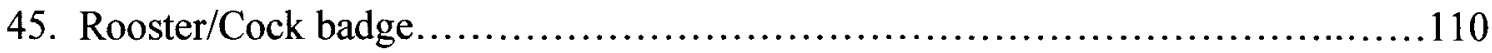

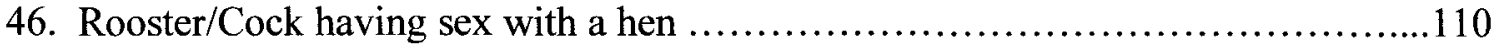

47. Troubadour riding an ambulant winged and belled phallus ......................111

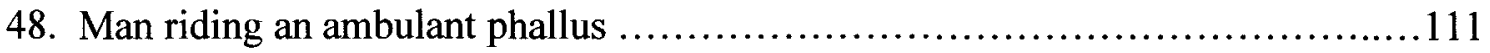

49. Woman pushing phallus-filled wheelbarrow atop an ambulant phallus .............111

50. Man pushing wheelbarrow atop an ambulant phallus ............................111

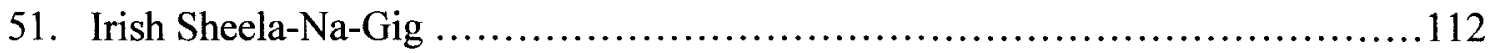

52. The Kilpeck Sheela-Na-Gig .................................................112

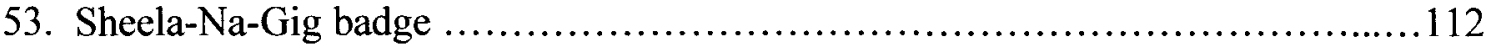

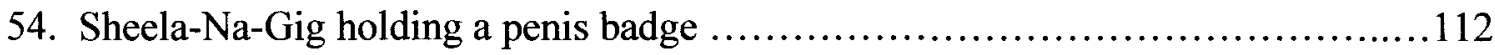

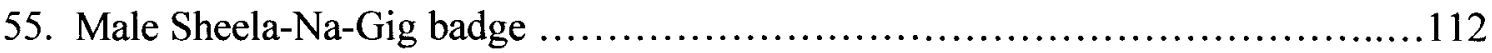

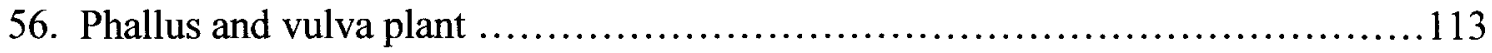

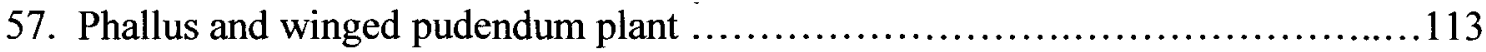

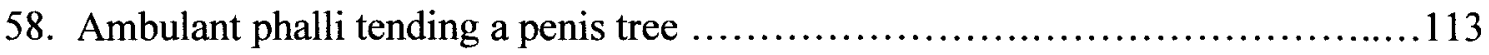

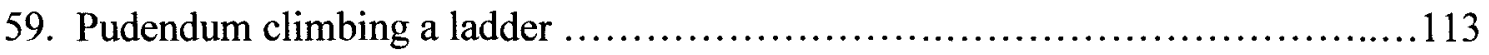

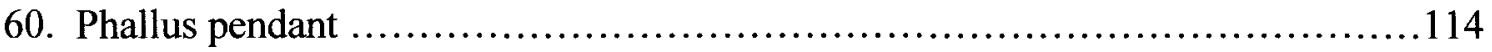

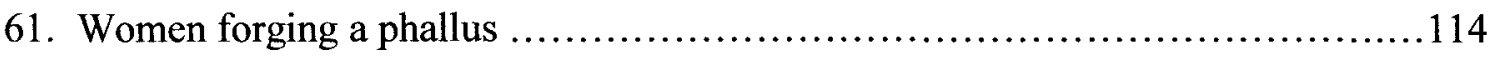

62. Ambulant phalli manning a sailing vessel ...................................114

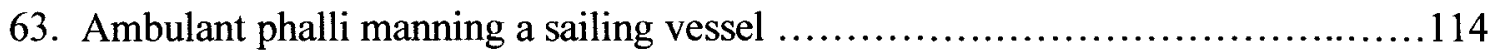

64. 'Hic Habitat Felicitas' plaque from Pompeii .....................................115 
65. Priapus fresco from the House of the Vettii in Pompeii

66. Priapic Mercury fresco from Pompeii ...................................... 115

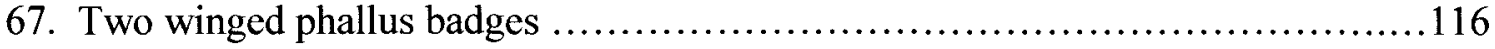

68. Tintinnabula from Herculaneum .............................................116

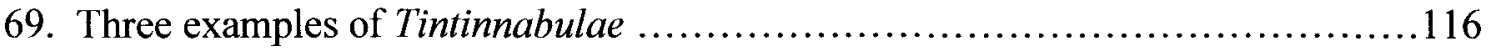

70. Floor mosaic from the House of the Evil Eye in Antioch .......................117

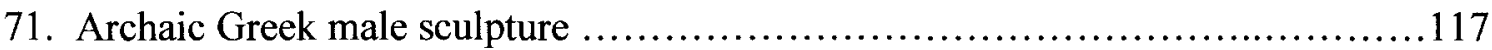

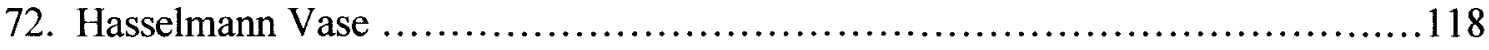

73. Detail of the Hasselmann Vase ..................................................118

74. Fragment of a Greek redware vase depicting a jar of disembodied phalli ...........118 


\section{CHAPTER I}

\section{INTRODUCTION}

Archaeological excavations of water sites during the previous two centuries throughout the Schelde Estuary in the Netherlands, and along the riverbanks of the Seine in France and the Thames in England, have brought to light a large corpus of enigmatic leaden pilgrimage badges dating from the mid-fourteenth to the early-sixteenth centuries. ${ }^{1}$ A small selection of the iconography of the curious corpus includes: ambulant vulvas on stilts, winged and crowned vulva pilgrims complete with pilgrims' staffs and rosaries, couples having sex, and ambulant winged phalli. The few scholars who have attempted their study have variously labeled the badges as erotic, obscene, rude, naughty, and pornographic. ${ }^{2}$ The advanced study of the tokens provides a "unique, and still largely untapped, perspective on late medieval devotional practice, the border between the sacred and profane, [and] the social as well as apotropaic function of ornament."3

Owing to the fact that historians generally view the late medieval period as an "age of faith," the existence of these remarkable objects raises some fundamental

\footnotetext{
' Jennifer Lee, "Beyond the Locus Sanctus: The Independent Iconography of Pilgrims' Souvenirs," Visual Resources XXI, no. 4 (2005): 363-81. Lee noted that so many specimens have survived due to the nature of tin and lead, which survive well in the anaerobic conditions of river-silt (375). See also Brian Spencer, Pilgrim Souvenirs and Secular Badges (London: The Stationary Office, 1998), 24.

2 The terms 'badges,' 'tokens,' 'amulets,' and 'signs' are interchangeable, and will be used throughout the paper when referring to the artifacts.

${ }^{3}$ Nicola McDonald, introduction to Medieval Obscenities, ed. Nicola McDonald (New York: York Medieval Press, 2006), 5.
} 
questions about the exact socio-religious nature of medieval culture. The primary questions, however, that need answering are: when, where, and for whom were the badges produced, and perhaps most importantly, why. An additional question that this essay will address is the cultural and social function the seemingly pagan, secular objects fulfilled in late medieval Dutch, English, and French society. Furthermore, the iconographically vivid badges will be shown to fit within the larger artistic trends of the medieval obscene and grotesque. It must be understood as historian Nicola McDonald proposes, that "the Middle Ages was, perhaps paradoxically, a period that appears to have accommodated, in ways our liberal society does not or seems not to, what we might broadly call the rude, bawdy or obscene." In the examination of the scholarship to follow, these central questions will be addressed, and a compelling and informed interpretation of the socio-cultural meaning and function of the tokens will be presented.

To say the least, the academic reactions to these amulets have been mixed. Given their graphic nature, the perplexing and enigmatic amulets have been variously interpreted as being parodies of popular religious devotion, as obscene images of lust and advertisements of sexual promiscuity, or even as a type of subversive social commentary on the late medieval craze for pilgrimage. ${ }^{5}$ The only consensus reached by scholars is that the badges broadly functioned as apotropaic devices - protecting their owners from

\footnotetext{
${ }^{4}$ McDonald, Medieval Obscenities, 2.

${ }^{5}$ Refer to the title of Jos Koldeweij's article, "Shameless and Naked Images: Obscene Badges as Parodies of Popular Devotion," in Art and Architecture of Late Medieval Pilgrimage in Northern Europe and the British Isles: Texts, eds. Sarah Blike and Rita Tekippe (Boston: Brill, 2005).
} 
the evil eye and other "noxious influences." It is significant to note, however, that no contemporary sources survive that speak of the tokens - they must, therefore, speak for themselves. Unfortunately, scholars from the mid-nineteenth century onwards have either completely shied away from their study due to the graphic nature of the images, or have subscribed to the belief that because they are so graphically uninhibited, a lurid pornographic meaning could be the only possible interpretation. This erroneous mindset still exists today, which makes it even more necessary to clarify the interpretive problems surrounding the study of these objects. The problems of interpretation are compounded by the fact that every scholar brings a different set of explanations to the academic table, giving rise to many theoretical opinions as to the badges' original social function and meaning.

It is remarkable that given the tokens' uniqueness in the body of late medieval art, they have received so little academic attention. A very narrow field of historians has published articles and books on these artifacts. Nicola McDonald, a historian who studies medieval obscenity, argues that "thus marginalized from mainstream academic discourse (whether wittingly or no), this extraordinary resource contributes not at all to current Anglo-American understandings of the complexity of medieval culture."” Furthermore, academic prudery, "as well as pervasive, if unspoken, social regulations about what kinds of subject matter can be legitimately and publicly discussed, are

\footnotetext{
${ }^{6}$ Thomas Wright, The Worship of the Generative Powers During the Middle Ages of Western Europe (1866). Republished as, Sexual Symbolism: A History of Phallic Worship Vol. II (New York: The Julian Press Inc., 1957), 59.

${ }^{7}$ McDonald, Medieval Obscenities, 8. See also Martha Easton, "Was it Good for You Too?: Medieval Erotic Art and Its Audiences," Different Visions: A Journal of New Perspectives on Medieval Art, Issue 1 (September 2008), 1.
} 
doubtless partly responsible for the absence of a sustained discussion of [the badges]. ${ }^{.8}$

Historian Martha Easton adds,

our history of medieval art is a constructed one, based on the intellectual, religious, and perhaps even moral predilections of the historians themselves. ... an increasing interest in ... sexual imagery in art is thwarted by a lack of available existing foundational research because of the virtual elimination of such topics ... from scholarly consideration. ${ }^{9}$

Academic prudishness cannot account solely for the paucity of scholarship. There are also great "lexical and semantic challenges inherent in the articulation of the obscene." ${ }^{10}$ Furthermore, as McDonald cogently argues, "no matter how carefully we choose our words, our use of language ... is never neutral; lexical choice, along with tone and register, always carries with it a complex set of cultural assumptions." ${ }^{11}$ For example, when looking at "Pussy Goes A' Hunting," a crowned and crossbow-armed vulva mounted on horseback (Figure 1), how are scholars to speak about it in serious academic terms? ${ }^{12}$ To define this image and others as 'pornographic' is not correctthey were never intended to arouse sexual desire in the modern sense of the word. ${ }^{13}$ 'Erotic' seems a somewhat safer choice, but the term still carries with it an arousing

\footnotetext{
${ }^{8}$ McDonald, Medieval Obscenities, 9. 'Academic prudery' is McDonald's term.

${ }^{9}$ Easton, Was it Good for You Too?, 2.

${ }^{10}$ McDonald, Medieval Obscenities, 9.

${ }^{11}$ Ibid., 10.

${ }^{12}$ Steve Millingham, who reproduces several of the badges for the Victoria and Albert Museum, gave the image this provocative title. McDonald, Medieval Obscenities, 10. ${ }^{13}$ John R. Clarke, Roman Sex: 100 BC - 250 AD (New York: Harry N. Abrams, 2003), 11. The German archaeologist C. O. Muller coined the term 'pornographic' in 1850 to write about prostitutes. Clark added, "Our concept of pornography depends on our judgments about what is [and is not] obscene."
} 
sexual connotation, and therefore does not work well either. ${ }^{14}$ Terms such as 'shameless' and 'lewd' impose a negative moral judgment onto the badges. Furthermore, to label them 'obscene' is also problematic - for, how are modern historians to know if the badges were in fact considered 'obscene' when they were produced, as no contemporary sources survive telling us so? To this "conceptual and terminological minefield," must add the further complication that central too was the "role of the medieval church in the production, regulation and consumption of obscenity ... much of what we identify as obscene seems to emerge from an ecclesiastical context, and most of the rest exists explicitly in dialogue with it." 16

When attempting to define the 'obscene' of any historical period, it is critical to remember that there is never any consensus across time and cultures as to what exactly constitutes the 'obscene.' Obscenity, therefore, is temporally and culturally specific what is obscene today in America may not have necessarily been obscene 650 years ago in Holland, and vice-versa. McDonald states that "definitions of the obscene are located at the juncture of what one group - usually the current dominant group - identifies, at a given moment, as decent or indecent." ${ }^{" 17}$ Historians of the subject should arguably omit terms such as erotic, obscene, pornographic, lurid, or other words with a moral or sexual charge from the dialogue. Each term listed above pigeonholes the objects into a definitive class to which they do not necessarily belong. Moreover, even though the

\footnotetext{
${ }^{14}$ Easton, "Was it Good for You Too?," 1. She claims she used the term 'erotic' in her title "to avoid the relativistic moral and judgmental potentialities of words such as 'obscene' and 'pornographic.'"

${ }^{15}$ McDonald, Medieval Obscenities, 12.

${ }^{16}$ Easton, "Was it Good for You Too?," 1. See also Spencer, Pilgrim Souvenirs, 15; Diana Webb, Medieval European Pilgrimage: c. $700-$ c. 1500 (New York: Palgrave, 2002), 33-35.

${ }^{17}$ McDonald, Medieval Obscenities, 12.
} 
tokens portray reproductive organs in a suggestive manner, a manner that does indeed have the ability to shock viewers, scholars have not substantially proven the images' links with medieval sexuality. Instead, scholars should use words such as evocative, bawdy, vivid, expressive, or graphic, providing a suggestive, yet more neutral meaning. These suggested descriptors are true, more impartial and less judgmental.

Through the analytical and chronological presentation of the available historiography on the objects to follow, it will be shown that the scholars who have published works on the tokens, with a few exceptions, offer flawed, contradictory, and ultimately invalid interpretations as to the badges' original social function and meaning. There is therefore a need for revisionist scholarship, covering areas of research that historians to date have completely overlooked and neglected. The primary goal of the present essay, therefore, is to explore the past and current scholarship on the subject in order to begin to rectify the situation.

The following chapters will address specific issues surrounding the evocative and bawdy badges. Chapter Two will discuss the available historiography surrounding the extant corpus of the leaden badges. Chapter Three examines the Black Death and the professional medical response. Chapter Four analyzes examples of the bawdy tokens from England, France, the Netherlands, and the Low Countries, arguing that the badges functioned as quasi medico-magical apotropaic devices against the spread of the Bubonic Plague. While the events and nature of the pandemic will be outlined in a broad sense, a deeper understanding of the plague itself - its epidemiological nature, how it was spread, as well as its variant forms - is not necessary to the intellectual understanding of the tokens. What is necessary, and where the focus of the discussion will lie, is perhaps with 
one of the most difficult aspects of the pandemic to quantify and to treat in any meaningful way. It is the personal and individual responses of late medieval people to the greatest disaster the world had ever known. As most scholars of the period would admit, the 'voice' of the common people is unquestionably hard to reconstruct; they did not generally leave behind a written record. What people did leave behind, and the 'voice' to be reconstructed by the present discussion, are the badges themselves. An untapped resource for the beliefs and thoughts of the late medieval Dutch, Flemish, English, and French men and women is found with the deeper study of these oftenmisinterpreted objects.

Chapter Five will examine historical iconographical antecedents of the tokens. The discussion will treat examples of Greek and Roman apotropaia, and especially objects that were held to be efficacious against the malevolent threat of the evil eye. It will be argued that in many respects, the late medieval secular tokens are related iconographically to the ancient material. Continuity of function between the ancient and late medieval examples is somewhat harder to reconstruct, though tentatively, one can offer that at least in the most general sense, the objects from both periods did function as apotropaic, protective devices. The conclusion will summarize the discussion of the preceding chapters and offer an interpretation of the badges designed to facilitate future academic study. The conclusion accounts for the intersections of the evocative badges, the social medico-magical responses from the period, the Great Mortality, the rise of Protestantism, the end of the primacy of the universal Catholic Church, and the end of subsequent outbreaks of the Bubonic Plague. The present attempt at understanding this enigmatic class of late medieval objects, however, does not seek to offer the definitive 
answer to what these objects meant and how they functioned during their period of consumption, c. 1350-1500 CE. There are still too many questions unanswered, and vast amounts of scholarship that need to be conducted before one could offer the answer.

This analysis, therefore, is a springboard, one that seeks to take the scholarly discussion forward in a meaningful way. The present essay is, moreover, the first of its kind; its methodological approach is one that no other scholar interested in the badges has attempted. It endeavors to bring together interdisciplinary scholarship from historians across varying fields of study, concerning an inadequately and admittedly misunderstood topic. One of the main difficulties in taking such an approach, however, is that the study can be hampered by the nature and lack of available evidence. Given this fact, some of the conclusions will be speculative, though it does not follow that they are erroneous or unfounded. Moreover, it does not follow that one cannot address a historical question that is not necessarily part of the larger academic discourse. When attempting to do so, however, one is left open to several possibilities. One can either shy away from the subject's study, afraid to go out on the proverbial limb, as others have done in the past, or, one can utilize the available resources to the best of their ability and attempt through careful reading to offer new insights and interpretations. This is an effort for the latter. By providing convincing evidence, further advanced study of the relationship between the evocative badges to the Great Pestilence will be justified. 


\section{CHAPTER II}

\section{A HISTORIOGRAPHICAL ANALYSIS OF THE BAWDY BADGES}

One not familiar with the corpus of enigmatic late medieval leaden badges to be discussed in greater detail to follow could wonder what can be gained academically from their study. A mid-to late-fourteenth century token depicting an ambulant pudenda turning a penis on a roasting spit over a vulva grease trap, may in fact, teach us a great deal (Figure 2). Key to the discussion, as one historian has noted, is that the study of the badges "provides a unique, and still largely untapped, perspective on late medieval devotional practice, the border between sacred and profane, the social as well as apotropaic function of ornament ... patterns of cultural and iconographic exchange, as well as persistently enigmatic attitudes towards sex and the display of sexual organs and sexual acts." Before delving into the in-depth analysis of the badges themselves, the discussion will begin with a summation of the available historiography.

There is not a great deal of scholarship on the tokens. Arthur Forgeais, an amateur French archaeologist, is generally regarded as the progenitor for the historical study of the tokens. Between 1848-1865, Forgeais fortunately, but inadvertently, stumbled upon the class of objects central to our discussion. In 1865 Forgeais published a sixteen-page booklet entitled Priapées, which illustrated 25 of the phallic and

\footnotetext{
${ }^{1}$ McDonald, Medieval Obscenities, 5.
} 
pudendum amulets he had excavated from the Seine, including the ten tokens seen in

Figure 3. ${ }^{2}$ Historian Denis Bruna remarked that Forgeais,

... obviously found [them] an awkward and embarrassing subject to place within [the] context of a supposedly pious Christian society and fell back on the ideas of earlier excavators of Pompeii who initially considered such a vast quantity of erotica could only have been associated with brothels and prostitutes ... Forgeais supposed that ... the wings of the phalli were assumed to designate eagerness and restless passion. ${ }^{3}$

Additionally, Bruna commented that overall, the text of Priapées "has a strong moralizing tone reflecting the author's views on the dangers of man's intelligence being enslaved by his physical organs. ${ }^{\text {4 }}$ If one considers the period in which Forgeais was writing, this viewpoint is not too surprising. It is also worth remembering that he was the first person to view these enigmatic objects, more than 400 years removed from their original social context. Forgeais was aware, however, that his beliefs surrounding the iconography of the tokens gave rise to an insufficient understanding of their original function, and that more scholarship was needed before definitively classing these objects as examples of medieval pornography. ${ }^{5}$ Other historians, spurred on by Forgeais, immediately began to publish further scholarship.

From 1866 to the 1920s, historians such as Frederick Elworthy, Lee Stone, and Thomas Wright focused significant attention on the apotropaic effects of magical amulets

${ }^{2}$ Denis Bruna, "Medieval Sexual Badges, Amulets and Tokens: Arthur Forgeais and Some Notes on His Life and Discoveries," translated extract from Enseignes $d u$ Pélerinage et Enseignes Profanes. Accessed at www. menantolstudio freeserve.co.uk/forgeais.htm (January 15, 2008), 5. No complete English translation of Priapées has been published to date.

${ }^{3}$ Bruna, "Medieval Sexual Badges," 6.

${ }^{4}$ Ibid., 5 .

${ }^{5}$ Ibid., 6. Bruna offered, "he recognized that his proposals did little to clarify the situation and hoped that a long-lost document waiting to be discovered might throw more light on the subject." 
against the ill effects of the evil eye. The historians of the period were of the belief that the late medieval owners and artisans of the amulets were carrying on classical traditions. For example, the ancient Greeks and Romans believed that to divert the harmful and sometimes-deadly gaze of the evil eye, one had to 'attract' its look by using a shocking image, and none was considered as effective as the male or female genitalia. In 1866 , the year following the publication of Priapées, Thomas Wright wrote at great length about the tokens discovered by Arthur Forgeais, and specifically on the classical foundations of the medieval use of "priapic figures as amulets, to be carried on the person as a preservative against the evil eye and other noxious influences. ${ }^{.66}$

Paramount to Frederick Elworthy's interpretation was the recognition of the late medieval belief that the bubonic plague could be transmitted through its gaze. ${ }^{7}$ In the introduction to his monograph published in 1895 on the evil eye, Elworthy observed, "belief in the evil eye is probably the oldest and most widespread of superstitions... It was common throughout Europe in the Middle Ages; and during the worst period of the Black Death it was generally supposed that the disease was communicated by a glance from the eyes of a sick person." ${ }^{, 8}$ Elworthy added, "nothing ... so much attracts or

\footnotetext{
${ }^{6}$ Wright, Worship of the Generative Powers, 59. See also Lee Stone, The Story of Phallicism (Chicago: Pascal Covici, 1927), 91.

${ }^{7}$ Frederick Elworthy, The Origins and Practices of Superstition: The Evil Eye (1895; reprint, New York: The Julian Press, 1958), ix, 34. For other scholarship on the late medieval and early modern European belief in the transmission of plague through eyesight, see John Aberth. The Black Death: The Great Mortality of 1348-1350, a Brief History with Documents (Boston: Bedford/St. Martins, 2005), 64. See also L. A. Joseph Michon, ed., Documents inédits sur la grande pesté de 1348, these pour le doctorat en médicine (Paris, 1860), 46-52, quoted in Rosemary Horrox, The Black Death (New York: Manchester University Press, 1994), 182. See also William Shakespeare, Love's Labour's Lost, Act V Scene 2, in G. R. Hibbard, ed., The Oxford Shakespeare: Love's Labour's Lost (Oxford: Clarendon Press, 1990), 211.

${ }^{8}$ Elworthy, The Evil Eye, ix.
} 
excites curiosity as obscenity and indecency; and hence of all amulets, those partaking of this character were the most potent, and therefore the most used [during the medieval period]." $"$ Elworthy referenced the Roman authors Pliny, Plutarch, and Juvenal, who wrote extensively on the evil eye and its successful diversion. ${ }^{10}$ Lee Stone continued the study of phallicism in the 1920s, drawing heavily upon Wright and Elworthy.

During the mid to late-nineteenth-century, and up until the $1920 \mathrm{~s}$, significant and groundbreaking research was conducted that is today still considered foundational, and referenced by all modern scholars working with the evocative tokens. Frederick Elworthy's astute observation of the link between the amulets and their protective function against the spread of the Black Death provides the foundation of my own research on the subject. The historical evidence for the amulets' use in this practice is remarkable and quite conclusive, and the discussion will return to this in much greater detail to follow. It is odd that other scholars have completely abandoned the theory. Indeed, as it will be seen later, no modern historian either continues or contradicts the argument, even though they reference other aspects of the earlier scholarship of Wright, Elworthy, and Stone. Arguably, the historiography from this early period provides the most tenable interpretations of the amulets, and is surprisingly - given the period in which they were written - less morally judgmental than what is found in much of the

${ }^{9}$ Ibid., 148.

${ }^{10}$ Plutarch, Symposia v. 7, quoted in Elworthy, The Evil Eye, 143. "Plutarch declares that the objects ... derive their efficacy from the fact that they act through their strangeness and ridiculousness of their forms, which fix the mischief-working eye upon themselves." See also Juvenal, The Sixteen Satires, trans. Peter Green, $3^{\text {rd }}$ ed. (London: Penguin Books, 1998), 11. In the second satire, lines 93-95, Juvenal mentions phallus shaped drinking glasses. See Figures 4-5 for an early sixteenth century German example, as well as a misericord from Bristol Cathedral of the same date. This is an area of scholarship that needs to be expanded. It can be argued that here are strong parallels between the medical function of the phallus glasses and the apotropaic badges. 
scholarship from the twentieth and twenty-first centuries. Certainly, the language and method of scholarship is dated, and one must be mindful of this fact when reading these earlier sources. It seems, however, that perhaps because the subject of the secular badges was so new, Wright, Elworthy, and Stone approached their study with an open and less jaded eye. Historical and literary theory had not yet invaded the field, and scholars, therefore, took the objects at face value and strove to find their iconographical and functional antecedents. Moreover, Wright, Elworthy, and Stone offered the best probable answer to the enigma of why the tokens were produced between 1350 and $1500 \mathrm{CE}$, when they made the compelling connection between the apotropaic function of the amulets against the spread of the plague.

Following Lee Stone's 1927 monograph, The Story of Phallicism, not a single scholarly work was published on the bawdy amulets until 1993 . The exact factors that lay behind this sixty-six-year lacuna in scholarship are unknown. One hypothesis is Nicola McDonald's 'academic prudery' theory. Another plausible reason is that the bawdy artifacts were not considered 'serious' enough for the academy, and discourse on graphic displays of male and female genitalia seems to have had simply no place in either the fields of history or art history. Historian Martha Easton commented on the lack of scholarship, and noted that the situation "probably stems more from a feeling that prevailed until very recently that naked, vulva-exposing women were problematic and inappropriate, unworthy of serious attention and too difficult to explain rather than from a lack of awareness of their existence or lack of interest in their existence."11 Why the historiographical situation changed in the 1990s is unclear, though in all probability, it

${ }^{11}$ Easton, "Was It Good for You Too?," 15-16. 
was due to the growing fields of social and gender history, with their increased interest in the scholarly study of sexuality and the erotic in medieval art.

In 1993, Dutch historians H.J.E. Van Beuningen and A.M. (a.k.a. Jos) Koldeweij published Heilig en Profaan 1, a seminal catalogue of 1000 examples of religious and secular pilgrims' badges in the private collection of Van Beuningen. ${ }^{2}$ In 2001, Heilig en Profaan 2 was published, containing over 1200 new images. ${ }^{13}$ Each badge, depicted actual size, is presented with the location where it was found, as well as a date of manufacture. Both books are invaluable catalogue of images, and their publication affords historians interested in the topic of secular pilgrims' badges an unequaled secondary source. Very little new scholarship, however, accompanies the catalogued images of the evocative badges; what little there is recounts mainly the earlier works of Arthur Forgeais and Thomas Wright, though curiously, Van Beuningen and Koldeweij do not mention Wright's theory of the amulets' plausible link to the Black Death.

Brian Spencer, a British historian, undertook a similar exercise with religious and secular examples found along the banks of the Thames, with the 1998 publication of his Pilgrim Souvenirs and Secular Badges. Spencer's catalogue provides new scholarship

\footnotetext{
${ }^{12}$ H.J.E. Van Beuningen and A.M. Koldeweij, eds. Heilig en Profaan: 1000 Laatmiddeleeuwse Insigne uit de collectie H.J.E. Van Beuningen (Cothen: Stichting Middeleeuwse Religieuze en Profane Insignes, 1993). Hereafter, this source will be abbreviated to HPI. Van Beuningen made millions through owning most of the Port of Rotterdam - one of the busiest in the world. With his money he amassed one of the largest collections of late medieval pilgrims' badges.

${ }^{13}$ H.J.E. Van Beuningen, A.M. Koldeweij, and D. Kicken, eds. Heilig en Profaan 2: 1200 Laatmiddeleeuwse Insigne suit openbare en particuliere collecties (Cothen: Stichting Middeleeuwse Religieuze en Profane Insignes, 2001). Hereafter, this source will be abbreviated to HP2. I am forever in debt to Jack and Elizabeth Kerpestein who provided the English translations used from the two above sources. The third installment, $H P 3$, will be published later this year.
} 
and insight into the production, sale and social function of religious and secular pilgrims' badges, and at the same time, provides a telling example of the pervasive 'academic prudery' surrounding the study of these objects. Spencer provides interesting English examples of secular apotropaic badges and amulets of a staid nature. More revealing, however, is his analysis of the iconography and function of the 'erotic' badges, followed by absolutely no images of those same items (the only type to be omitted in the catalogue of more than 1200 examples). Nicola McDonald, frustrated as well by this fact noted, "scholarship dedicated to the badges themselves is, likewise, often peculiarly silent and silencing in its treatment of the sexual material ... [Brian Spencer] completely obliterates all genital or sexual material from the visual record." ${ }^{\prime 4}$ Given the fact that Spencer published his book in the late $1990 \mathrm{~s}$, one is left to wonder what exactly led him to be reluctant to reproduce the images. It is an unfortunate omission from the already scant historiographic record, and one that does a great disservice to the further study of the objects.

At this point, it is necessary to delve a little deeper into the scholarship provided by Malcolm Jones and Jos Koldeweij. Jones and Koldeweij have written more on the badges than any other scholars. In 2002, Malcolm Jones published The Secret Middle Ages. ${ }^{15}$ What is most frustrating about Jones is that he comes very close to hitting the proverbial nail on the head, and then he offers some excruciatingly odd interpretation of the badges' original use. It is best to begin with the positive aspects of his work, for he does, undeniably, offer some very astute scholarship. Jones noted that "these emblems have revealed new depths to the fantastical, bold, rude and secular mentalite of the

\footnotetext{
${ }^{14}$ McDonald, Medieval Obscenities, 9.

${ }^{15}$ Malcolm Jones, The Secret Middle Ages (Westport, Connecticut: Praeger, 2002).
} 
ordinary medieval man and woman."16 This is certainly true. He goes on to aver "that henceforth any history of late medieval art or culture that purports to describe that era without taking this material into account will be fundamentally flawed." 17 This might be a bit of an over-statement, but he does have a valid point. He correctly argues that the badges in $H P 1$ and $H P 2$,

necessitate a serious rethink of late medieval popular iconography in general .... Almost all such sexual badges were not intended as 'erotic' in the sense of provoking sexual arousal, but principally as apotropaic - by the exposure of the genital icon, whether male or female, they were intended to disarm the ever-present yet vague malevolence known as the Evil Eye. ${ }^{18}$

Jones, drawing on Wright and Elworthy, agrees that there is an undeniable tie with Roman iconographic antecedents, especially with first-century CE examples of phallic wind chimes, or tintinnabulae. ${ }^{19}$

The problem with Malcolm Jones is that he falls short on several fundamental matters. First, he entitled the chapter of his book that deals with the evocative amulets "Wicked Willies with Wings." While certainly humorous and attention getting, like the modern title given to "Pussy Goes A' Hunting," (Figure 1), Malcolm's lexical choice of words is highly problematic. Nicola McDonald observed, "Pussy, like other diminutives

\footnotetext{
${ }^{16}$ Jones, The Secret Middle Ages, xiv.

${ }^{17}$ Ibid., 249.

${ }^{18}$ Ibid., 248.

${ }^{19}$ Ibid., 253-54. Jones noted with regards to the tintinnabulae that, "not only is there an obvious similarity between such pendants and the medieval phallus badges, but the fact that the latter frequently bear a bell around the 'neck' of the phallus, lead me to suggest ultimate derivation from just such Roman models, perhaps due to the discovery of a cache of bronzes including tintinnabula in the late medieval Netherlands." The significance of the bell is that noise was widely believed by the Romans (and medieval Europeans) to be one of the methods to dispel the evil eye. See Spencer, Pilgrim Souvenirs (1998), Clarke, Roman Sex (2003), and Van Beuningen and Koldeweij, HPI (1993), and Van Beuningen, Koldeweij, and Kicken, HP2 (2001) for more of the discussion.
} 
[i.e. 'willies'] used for the generative organs, works to deflect the vulva's [or penis's] blatant sexual charge, reducing, through humor, the potential for offence."20

Furthermore, why does Jones feel the need to term them 'wicked'? By so strongly arguing earlier in his book for their being taken seriously in the academic world, and then deflating their significance through the use of humorous colloquialisms, he undermines his own cause.

Semantics is not, however, where Jones reveals his biggest flaws. He writes at great length about the apotropaic function of the amulets, as well as their ultimate iconographic foundation in the classical world. He agrees that by nature, a device designed to dispel the evil eye had to 'attract' its glance - therefore, of necessity, it must be worn on the outer garments, or hung conspicuously in the home. Jones then completely negates his entire argument when he poses the question if they were perhaps worn secretly under the owner's clothing because they were so graphic. ${ }^{21}$ He even went so far as to title his book The Secret Middle Ages, after this theory. Nicola McDonald remarked that Jones "evidences a peculiar logic in his determination to expose ... the vigorous excesses of the sexual badges only then to imagine that many of them were intended to be worn beneath the outer clothing and thus not visible to human eyes."22 There is absolutely no foundation for Jones' erroneous assumption in the historical evidence. While he is willing to treat the objects academically, he resorts to placing his own moral filters onto the subject through his word choice and final interpretations when

${ }^{20}$ McDonald, Medieval Obscenities, 10.

${ }^{21}$ Jones, The Secret Middle Ages, 249.

${ }^{22}$ McDonald, Medieval Obscenities, 9. 
he argues that because of the badges' shocking nature, they could not possibly have been deemed acceptable to wear on their owner's outer clothing.

The Dutch historian Jos Koldeweij is even more problematic in his approach to the tokens. Unfortunately, he is considered to be the foremost authority on the subject, owing to his role in the publication of $H P 1$ and $H P 2$, as well as other articles. It appears, however, since the publication of Nicola McDonald's work referenced throughout this essay, that the tide of scholarly opinion is turning against Koldeweij. To give evidence to this argument, a brief analysis of one of his articles follows.

In the most general sense, Koldeweij appears to be fundamentally offended by the objects that have made his career. He consistently refers to them as "obscene," "dirty," and "shameless." ${ }^{23}$ He rails against uncontested scholarship that the medieval badges' iconography and apotropaic function date back to the classical world. Koldeweij offered, "the Roman erotica exhibit a remarkable high degree of abstraction and differ markedly from the almost absurd, realistic medieval fantasies ... this much older [Roman] material cannot be obviously related to it in terms of continuous tradition. ${ }^{24}$ With the deeper analysis of examples of Roman apotropaia that follows, one can clearly see that Roman 'erotica' does not, in fact, differ greatly from the 'absurd, realistic medieval fantasies.'

While Koldeweij does consent that the badges broadly functioned on an apotropaic level, he seems unable to get past the sexual tenor of the iconography when assigning original socio-cultural function. He bizarrely claimed that "those who wore

${ }^{23}$ Koldeweij, "Shameless and Naked Images," 493-510. The badges are consistently referred to as "absurd," "erotic," "lewd," and "obscene." Most of Koldeweij's publications follow the same line of interpretation, thus the discussed provides a good example of his entire corpus. See also Van Beuningen, Koldeweij, and Kicken, HP2. ${ }^{24}$ Koldeweij, "Shameless and Naked Images," 501. 
these sexual amulets undoubtedly wanted to hunt or be hunted. ${ }^{, 25}$ In other words, Koldeweij argues that the badges functioned as lewd medieval sexual calling cards, advertising their owner's promiscuity and availability. There is absolutely no historical evidence for this erroneous assertion. Koldeweij goes on further to purport that the badges were parodies of popular religious devotional practices as well. He referred to Figure 6, which shows a crowned pudendum being carried on a processional bier by three ambulant phalli. Koldeweij noted that, "the association with a religious procession will have been evident to everyone of that period who saw the brooch. ${ }^{26}$ While this is probably true, in stating the obvious, he overlooks the deeper significance of their meaning.

Describing another class of amulets, the Pudenda Pilgrim (see Figure 7 for one example), Koldeweij concludes that this type of image refers to male anxieties over female pilgrims. He argued, "of course these badges allude to activities which could take place among the group of pilgrims and which were neither pious nor devotional ... despite Christian morality, pilgrims were often unable to resist the temptation of the flesh on their travels. ${ }^{, 27}$ That there were historical social anxieties recorded about the 'dangers' of women going on pilgrimage is undeniable. That men and women pilgrims enjoyed each other's sexual company while traveling is also likely equally true. But why

\footnotetext{
${ }^{25}$ Ibid., 504.

${ }^{26}$ Ibid., 506.

${ }^{27}$ Ibid., 508-10. He refers to a 1497 chronicle of a German pilgrim to Santiago who took home the new (to Europe at least) disease syphilis, as a "souvenir of their journey," and conjectures that the badges were made as a warning against catching the disease. The problem is this - the pudenda pilgrims were all produced between $1350-1425$, roughly 75 years before the introduction of syphilis from the New World. One theory of transmission holds that the first reported case in Europe was in 1493, by one of the captains on Columbus' voyage.
} 
would the ambulant pudenda pilgrims be the only ones produced in response to these specific fears, and what about the rest of the iconographic corpus? Koldeweij offers no explanation for more than one hundred similar badges, some of which display ambulant phalli manning sailing vessels, variants of the Irish church decorations Sheela-Na-Gigs, pudenda turning roasting penises on spits, pudenda climbing ladders, pudenda on stilts, and ambulant phalli, just to name a few of the common types of bawdy amulets (Figures $8-13)$.

The majority of scholarship from the last decade of the twentieth century can be summed up as more cataloguing in nature, and interpretation, when it is offered, is rather superficial and off-the-mark. Upon reading the few available sources from this decade, it seems that scholars were still afraid, in some instances, to make an academic name for themselves with the study of medieval erotica. None strove to expand on the works of Arthur Forgeais, Thomas Wright, and Frederick Elworthy, which at that point were more than 100 years old.

In the twenty-first century, academia is slowly, and grudgingly, beginning to change for the better with regards to the amulets. Interdisciplinary methodologies are being used and finally, modern scholars are beginning to offer new theories 147 years after the initial interpretations offered by Arthur Forgeais. This is not to say, however, that current interpretations are necessarily valid, or even founded on the available historical evidence. Indeed, books and articles written since 2000, with a few exceptions, have proven to be the most problematic. Part of this, arguably, is due to the fact that the five contemporary historians of the subject seem unwilling to offer any explanation of the badges, other than that they functioned broadly as protective, apotropaic devices. In 
actuality, after analyzing all of the scholarship from the last 150 years, the foundations Wright, Elworthy, and Stone laid are the soundest. They offer the most plausible interpretations and their works should serve as the starting point for any modern inquiries on the badges.

Historian Nicola McDonald, with her 2006 publication of Medieval Obscenities has only recently academically contested, in her brief twelve-page introduction, the two main historians on the subject, Jos Koldeweij and Malcolm Jones. McDonald is the first contemporary historian to throw down the proverbial academic gauntlet. She arguably lays the foundation for future scholarship of the badges and medieval obscenities in general. McDonald points out that "medieval obscenities challenge us, and demand our critical attention, because they arrest us with both their shocking modernity and their radical otherness. ... the obscene is a category that demands that we rethink our own assumptions and preconceptions of the Middle Ages. ${ }^{, 28}$

In summarizing the scholarship of this decade, it can be stated that there are methodological flaws and inconsistencies, though this situation is slowly changing for the better. Historian Malcolm Jones is more on the right track. He weakened his argument, however, when he proposed that the badges were secretive objects. He seems unable to accept the idea that these were socially acceptable forms of ornamentation, produced in response to a specific cultural need. Nicola McDonald offers a refreshing approach, and her call for further scholarship may provide the impetus for further study of the subject. Historian Martha Easton offers an additional fresh look at the social role of medieval erotica in general, and notes that these 'images on the edge,' using Michael Camille's

${ }^{28}$ McDonald, Medieval Obscenities, 11. 
phrase, "seem to be areas in which the proper order of things is reversed, the world is turned upside down, and the transgressive may be depicted, perhaps in order to render it powerless, perhaps to harness its power as protective. ${ }^{, 29}$ Jos Koldeweij's approach, on the other hand, is scattered and random, and he consistently contradicts himself.

According to Koldeweij, the badges were at once promiscuous sexual advertisements, satires of popular religious practices, a response to women going on pilgrimage, and lastly, as a cautionary tale against contracting syphilis (see footnote 44). In short, he doesn't know how to categorize, or interpret the badges.

${ }^{29}$ Michael Camille, Image on the Edge: The Margins of Medieval Art (Cambridge: Harvard University Press, 1992). Easton, "Was it Good for You Too?," 15. It is outside the scope of this essay to delve into the theoretical arguments on the transgressive and carnivalesque tendencies to temporarily reverse the social order. There is, however, a great deal of scholarship on the subject. Arguably, in a greatly expanded examination of the topic of the sexually explicit badges, one can find substantive relations to theories of the carnivalesque. If one is interested in reading further, refer to: Mikhail Bakhtin, Rabelais and His World, trans. Helene Iswolsky (Cambridge, MA.: Massachusetts Institute of Technology Press, 1968); Mikhail Bakhtin, Problems of Dostoevsky's Poetics, ed. and trans. Caryl Emerson (Minneapolis, MN.: University of Minnesota Press, 1984); Simon Dentith, Bakhtinian Thought: An Introductory Reader (London: Routledge, 1995); Victor Turner, The Ritual Process: Structure and Anti-Structure, $2^{\text {nd }}$ ed. (London: Aldine Transaction, 2008); Timothy Hyman and Roger Malbert, Carnivalesque (London: Hayward Gallery Publishing, 2000); Peter Burke, Popular Culture in Early Modern Europe, $3^{\text {rd }}$ ed. (Burlington, VT.: Ashgate, 2009); Johan Huizinga, The Autumn of the Middle Ages, trans. Rodney J. Payton and Ulrich Mammitzsch (Chicago: University of Chicago Press, 1996); Johan Huizinga, Homo Ludens: A Study of the Play-Element in Culture (New York: Roy Publishers, 1950); Natalie Zemon Davis, "Women on Top," in Society and Culture in Early Modern France (Stanford: Stanford University Press, 1975); Natalie Zemon Davis, "The Reasons of Misrule: Youth Groups and Charivaris in $16^{\text {th }}$ Century France," Past \& Present 50 (1971): 41-75; Edward Muir, Civic Ritual in Renaissance Venice (Princeton: Princeton University Press, 1981); and for a masterful book that discusses interpretive problems contained within the previous theories of the carnivalesque, see Chris Humphrey, The Politics of Carnival: Festive Misrule in Medieval England (Manchester: Manchester University Press, 2001). I am forever grateful to Dr. John Hunt, who conducted a Directed Study with me on this topic during the Fall of 2010. My apologies to him are due for the simple fact that I could not fit these sources into the present discussion. 
Upon analyzing the available, thought scant, scholarship on the evocative badges, it is apparent that serious, revisionist scholarship is needed. None of the modern scholars provide a valid an answer to the enigma of why the badges were produced between c. 1350-1500 CE in France, England, the Low Countries, and especially the Netherlands. If we are to gain a better understanding of this class of objects, this question must be answered. It is not enough to state that they functioned as protective devices, and then not successfully define what they were supposed to be protecting their owners against. Arguably, the answer to the why is actually very simple, and hiding in plain view - the catastrophic health crisis that reached European shores in 1347 - the Great Pestilence as it was known then, or Black Death as it is commonly referred to now. 


\title{
CHAPTER III
}

\section{THE GREAT PESTILENCE AND THE PALLIATIVE}

\author{
MAGICO-MEDICAL RESPONSE
}

\begin{abstract}
A privee theef men clepeth Deeth, That in this contree al the peple sleeth, And with his spere he smoot his herte atwo, And wente his way withouten wordes mo. He hath a thousand slayn this pestilence.
\end{abstract}

I, as if among the dead, waiting till death do come, have put into writing truthfully what I have heard and verified. And that the writing may not perish with the scribe and the work fail with the laborer, I add parchment to continue it, if by chance anyone may be left in the future, and any child of Adam may escape this pestilence ...

As it was noted in the introduction, this essay will not treat in great depth the subject of the plague, for in many respects, the plague is not the focus of the present exercise. With regards to the pandemic, what is undeniably necessary for the discussion is an analysis that provides a framework for the broader examination of the individual

${ }^{1}$ Geoffrey Chaucer, "The Pardoner's Tale" from the Canterbury Tales, quoted in John B. Friedman. "He Hath a Thousand Slayn this Pestilence: The Iconography of the Plague in the Late Middle Ages," in Social Unrest in the Late Middle Ages: Papers of the Fifteenth Annual Conference of the Center for Medieval and Early Renaissance Studies, ed. Francis X. Newman (Binghamton, NY.: Center for Medieval and Early Renaissance Studies, 1986), 77.

${ }^{2}$ John Clyn, Annalium hiberniae chronicon, trans. and ed. R. Butler (Dublin: Irish Archaeological Society, 1849), 37, quoted in Robert S. Gottfried, The Black Death: Natural and Human Disaster in Medieval Europe (New York: The Free Press, 1983), 67. Clyn was a Minorite monk in Kilkenny, Ireland. Shortly after he recorded the above entry in 1349 , another hand concludes, "Here it seems the author died." 
social and medical responses to the plague. ${ }^{3}$ It is at the intersection of the above where the focus lies, though of necessity, the general facts surrounding the plague will be outlined below.

To provide context, a brief epidemiological discussion of the plague is in order. Since the 1980 s there have been widely divergent scholarly opinions as to what biologically constituted the Great Pestilence. ${ }^{4}$ The strongest arguments, and indeed the most supported by the actual physical, written, and DNA evidence, hold that the Great Pestilence was caused by the bacterium Yersinia pestis. Significantly, there is some very

${ }^{3}$ During the contemporary outbreaks beginning in 1347, the Second Pandemic of the Bubonic Plague was called either the Great Pestilence or the Great Mortality. For the remainder of the essay, the terms epidemic, pandemic, the plague, the Bubonic Plague, the Black Death, the Great Pestilence, and the Great Mortality will be used interchangeably. To distill and condense the enormous subject of the Black Death into a few brief pages is a difficult, if not impossible, task. There are literally dozens of historians who have written on the plague - while some will be referenced above, there are many others whose work does not fit within the scope of the present essay. Given this fact, much of the available scholarship on the subject will be dealt with in the footnotes, so that those interested in reading more, or those interested in where I have located information can read further.

${ }^{4}$ This essay is not the place to delve deeply into the arguments, but a mention of several historians with interpretations varying the most from the general consensus follows. See Graham Twigg, The Black Death: A Biological Reappraisal (Berlin: Schocken Books, 1984). Twigg was the first to argue that the pandemic was not Bubonic Plague. For a work that argues the pandemic was Hemorrhagic Plague (an Ebola-like virus), see Susan Scott and Christopher Duncan, Return of the Black Death: The World's Greatest Serial Killer (Chichester: Wiley \& Sons, 2004), and for a historian who argues it was Anthrax, see David Herlihy, The Black Death and the Transformation of the West, ed. Samuel Cohn (Cambridge, Mass.: Harvard University Press, 1997). See also Samuel K. Cohn Jr., The Black Death Transformed: Disease and Culture in Early Renaissance Europe (New York: Arnold Publishers, 2002). Currently, these revisionist theories are no longer held as valid, and most scholars of the Black Death discount the above proposals due to the overwhelming physical and medical evidence that supports Yersinia pestis, or a variant strain of Yersinia as the culprit. For an interesting environmental approach, see Robert S. Gottfried, The Black Death: Natural and Human Disaster in Medieval Europe (New York: The Free Press, 1983). For a useful book that outlines all of the contemporary epidemiological arguments, see Joseph P. Byrne, The Black Death (Westport, Conn.: Greenwood Press, 2004). 
new evidence published in October 2010 that finally lays to rest the argument of whether or not the Black Death was caused by Yersinia pestis. ${ }^{5}$ Scientists Stephanie Haensch, Raffaella Bianucci, Michel Signoli, Minoarisoa Rajerison, et. al., studied skeletal DNA and protein signatures from mass plague graves in northern, central, and southern Europe. In their published findings, the team concluded, "we confirm that $Y$. pestis caused the Black Death and later epidemics on the entire European continent over the course of four centuries."

Yersinia pestis is a bacterium that multiplies violently fast. The bacterium is carried in both the stomachs of animal fleas (Xenopsylla cheopsis) and human fleas (Pulex irritans). The infected fleas must feed constantly because their stomachs are full of plague bacillus and there is no room for the blood they feed on. When such a "blocked" flea bites its host, it regurgitates a mixture of blood and bacterium into the host, and thus transmits the disease. ${ }^{7}$ Once the host dies, the fleas need a new food source - which is sometimes human. Robert S. Gottfried, a historian of the plague who follows an ecological approach to the transmission of the disease, offered that humans "are not a preferred host for $Y$. pestis, but rather, the victims of an animal epizoötic. In effect, humans are victims of changes in insect and rodent ecology.",

5 www plospathogens.org/article. NB: search under "Yersinia" to locate the article. ${ }^{6}$ Ibid. The team also significantly noted that "on the basis of 17 single nucleotide polymorphisms ... our DNA results identified two previously unknown but related clades of $Y$. pestis associated with distinct medieval mass graves. These findings suggest that plague was imported to Europe on two or more occasions, each following a distinct route. These two clades are ancestral to modern isolates of Y.pestis Orientalis and Medievalis."

${ }^{7}$ This process is described in multiple sources, but for one example, see John Aberth, From the Brink of the Apocalypse: Confronting Famine, War, Plague, and Death in the Later Middle Ages (New York: Routledge, 2001), 111.

${ }^{8}$ Gottfried, The Black Death, 7. 
Furthermore, there are three types, or manifestations of plague - which differ due to the manner in which the bacterium is spread. The first, spread by the bite of a "blocked" flea, is Bubonic Plague and is the most common and the least deadly of the three. One of its most characteristic symptoms are buboes, from which the disease gets its name. Buboes are large, blackish, gangrenous pustules that form at the lymph nodes. Death occurs within five days in about $60 \%$ of the cases. Pneumonic Plague occurs when Yersinia pestis enters the pulmonary system, and within three days, has a 95\% - 100\% lethality rate. The pneumonic form is most prevalent and virulent in cooler temperatures. The last form of plague is the least common and has the highest rate of lethality. Septicaemic plague, which is blood borne through perhaps insect bites, kills $100 \%$ of its victims within hours, though the exact nature of its transmission is not scientifically understood. ${ }^{9}$ During the period between 1347-1350 all three variants, at one time or another and sometimes simultaneously, were raging throughout the European continent and England.

Exactly how the disease reached Europe is generally not contested in contemporary scholarship, and a brief outline of transmission follows. ${ }^{10}$ For reasons that are still not fully understood by historians or scientists, sometime between 1338-1339 in

\footnotetext{
${ }^{9}$ For the above, see Aberth, From the Brink of the Apocalypse, 111-112. See also Gottfried, The Black Death, 8.

${ }^{10}$ For further reading on the routes of transmission, and instructive discussions of the Black Death in general, see Philip Ziegler, The Black Death (New York: The John Day Company, 1969); Aberth, From the Brink of the Apocalypse; Aberth, The Black Death; Gottfried, The Black Death; Byrne, The Black Death; Colin Platt, King Death: The Black Death and its Aftermath in Late-Medieval England (Toronto: University of Toronto Press, 1996); Charles F. Mullet, The Bubonic Plague and England: An Essay in the History of Preventative Medicine (Lexington, KY.: University of Kentucky Press, 1956), and John Kelly, The Great Mortality: An Intimate History of the Black Death, the Most Devastating Plague of All Time (New York: Harper Collins, 2005).
} 
the area of Lake Issyk Koul in the Semiriechinsk district of Central Asia, a normally contained local endemic epizoötic form of Bubonic Plague spread eastwards to China, south to India, and west to the Crimea by $1346 .{ }^{11}$ Near the end of 1346 , rumors brought back from merchants and travelers, reached Europe that told of a catastrophic plague raging in the East. Many feared that it was only a matter of time before it would reach Europe. Their fears were justified. In October 1347, a Genoese fleet infected with the plague landed in Sicily's Messina harbor. The Great Pestilence had reached European shores and reared its nasty head in a catastrophic manner that has never been equaled. The Franciscan friar Michele da Piazza, who lived in Catania, Sicily, provided what is believed to be the first record of the arrival of the plague in Europe. It is from his Chronicle (1347-1361) that we learn of the Genoese fleet. Michele da Piazza recorded: ... twelve Genoese galleys, fleeing our Lord's wrath which came down upon them for their misdeeds, put in at the port ... of Messina. They brought with them a plague that they carried down to the very marrow of their bones, so that if anyone so much as spoke to them, he was infected with a mortal sickness which brought on an immediate death ... the signs of death which the Genoese and Messinese shared were these: among those talking together, the breath of infection spread equally among them, until one infected the other ... there arose certain pustules the size of a lentil ... the plague thus infected and penetrated the body so that its victims violently

${ }^{11}$ Ziegler, The Black Death, 25. See also Aberth, From the Brink of the Apocalypse, 120. Aberth offered, "disasters such as a rain of frogs or of fire that were reported to have taken place in the East indicate that some kind of natural upheavals - floods, earthquakes, drought - brought the squirrel-like Manchurian marmot, continuous carriers of the plague bacillus, into contact with humans amid the steppes of central Asia." For an environmental and ecological interpretation of the spread of the Black Death, see Gottfried, The Black Death, xv - 35. Gottfried's approach was rather interesting. He analyzed how weather patterns in the region affected native rodent and flea populations. He argues that it is only by taking this into consideration, along with the role played by humans in the transmission of the disease, that one can understand how the Second Pandemic of the Bubonic Plague originated and spread. Volcanic and seismic activity may have also prompted the marmot migration that led to the pandemic. 
spat out blood and this . . . continued incessantly for three days until they expired. $^{12}$

With a ferocity, morbidity, and lethality incomprehensible to contemporaries, the plague ravaged the island and quickly spread along the common trade routes from the nexus of the original contagion point. Guy de Chauliac, a contemporary physician to the Avignonese popes noted, "and I cleep [call] it the grete deeth, for it occupied all the worlde." ${ }^{.13}$ Indeed, as John Aberth remarked, "the Black Death of 1348-1349 was unique in history. Never before and never since has so much disproportionate death come in such a short period of time."14 Estimates of mortality given by historians vary, but the general consensus holds that approximately 25 to 35 million Europeans - roughly one third to one half of Europe's population - died in the first outbreak of plague that ended in 1350. Worldwide, the mortality figures for 1347-1350 approached 100 million. $^{15}$

${ }^{12}$ Michele da Piazza, Cronaca, ed. Antonino Giuffrida (Palermo: ILA Palma, 1980), 82, 86, quoted in Aberth, The Black Death, 29.

${ }^{13}$ Guy De Chauliac, The Cyrugie of Guy De Chauliac Vol. 1, trans. and ed. Margaret S. Ogden (London: Early English Text Society, Oxford University Press, 1971), 155.

${ }_{14}^{14}$ Aberth, From the Brink of the Apocalypse, 110.

${ }^{15}$ To bring these numbers into contemporary terms provides an astounding figure that brings the sheer magnitude of the medieval event into perspective. The world population c. 1350 was approximately 400 million. See John D. Durand, "Historical Estimates of World Population: An Evaluation," Population and Development Review 3 (Sept., 1977): 256. If close to 100 million people died in the first outbreak, between 1347-1350, this equated to roughly $25 \%$ of the world's population dying within three years. If an identical pandemic occurred today, with a current population of 6,991,998,419 (according to the World Population Clock, accessed at wnis.census gov (2/4/2012), with the same mortality rates, it would mean that approximately 1.75 billion people would die worldwide in less than three years. There have been three major pandemics of plague during the last 1500 years. The First Pandemic of Bubonic Plague is commonly known as the Justiniac Plague. It originated in Arabia, spread to Egypt by $542 \mathrm{CE}$, devastated the Byzantine Empire, and reached Ireland by $664 \mathrm{CE}$. The Second Pandemic of Bubonic Plague lasted roughly from 1338-1720 CE. The Third Pandemic erupted in Yunnan, China in 1892, and spread to Bombay, India by 1896. Six million people died in India alone during the last known outbreak of plague. See Ziegler, The Black Death, 25. 
After coming to terms with figures such as those listed above, and putting aside questions of long-term effects of the biological disaster, the years 1347-1350 ushered in a psychologically devastating pattern of ever-present death for late medieval and early modern Europe for roughly the next four hundred years. ${ }^{16}$ Historian Colin Platt observed that "it was the first 150 years ... that Christian men and women learnt to live with plague. Another thing they learnt was how to die of it." ${ }^{17}$ Indeed, there would be recurrent outbreaks in England and Europe, some nearly as devastating as the first, in almost every decade leading up to the seventeenth century. ${ }^{18}$ Historian Charles Mullet remarked that the plague "periodically attacked large sections of Europe for at least 400 years, and although its mortality, extent, and influence probably never again equaled those of the mid-fourteenth century, it often reached spectacular figures and revolutionized life in limited areas."

\footnotetext{
${ }^{16}$ It is believed that the last known outbreak of the Second Pandemic of plague occurred in 1743 in Messina, Sicily. Messina, therefore, was the first in 1347, and the last in 1743, European city affected with plague, exactly 396 years apart. See George Huppert, After the Black Death: A Social History of Early Modern Europe, $2^{\text {nd }}$ ed. (Bloomington, IN.: Indiana University Press, 1998), ix. Huppert provided some interesting points of discussion. He failed, however, to impress with his treatment of the Black Death. Huppert claimed in the introduction that any discussion of the plague itself would not appear in his book. He went on to support a Malthusian interpretation of the plague, and claimed, "after the Black Death had done its work, the survivors became more prudent. They did not allow themselves the luxury of multiplying again to the point of outstripping their resources as drastically as they once had. To forestall [disaster], they learned to control population growth." (ix). For the general arguments against the Malthusian theory, see Ziegler, The Black Death, 33-34.

${ }^{17}$ Platt, King Death, vii.

${ }^{18}$ The list of fourteenth and fifteenth century outbreaks of plague alone, reads: 13471350, 1361-62 (also known as the Pestis Secunda), 1369 (known as the Pestis Tertia, or the Children's Plague), 1374-79, 1390-93, 1400, 1405-06, 1407, 1410-11, 1413, 1420, 1423, 1426-29, 1433-35, 1438-40, 1450-54, 1463-64, 1467, 1471, 1479-80, and 1492-94. See Aberth, From the Brink of the Apocalypse, introduction; Gottfried, The Black Death, 131-133; Kelly, The Great Mortality, 278.

${ }^{19}$ Mullet, The Bubonic Plague, 14.
} 
Ages the plague was ... totally incomprehensible. Medieval man was equipped with no form of defense - social, medical or psychological - against a violent epidemic of this magnitude. $" 20$

The psychological devastation brought on by the Great Pestilence and subsequent epidemics can be understandably hard for a modern person to comprehend. We have never faced a similar biological catastrophe. The writings of the poet Geoffrey Chaucer and the monk John Clyn provided at the introduction to this chapter are but two examples of the unmistakable feelings of despair, hopelessness, and utter impotence late medieval people evinced in the face of the Great Pestilence. ${ }^{21}$ There are hundreds of surviving first-hand accounts that speak to the incomprehensible emotions and gruesome scenes that raged throughout Europe for more than four hundred years. For the purposes of the present examination, only a few examples of contemporary accounts will be noted in order to provide at least a modicum of the cultural mentality of a plague-stricken Europe.

Living in Siena, Italy, Agnolo di Tura del Grasso recorded in his Sienese

Chronicle (1348-1351) one of the most poignant accounts of the physical and emotional destruction wrought by the plague, and as such, it is worth quoting at length. He lamented,

I do not know from where came this cruelty or these pitiless ways, which were painful to see and stupefied everyone. There are not words to describe how horrible these events have been ... and in many places in Siena great pits were dug and piled deep with the multitude of dead. And they died by the hundreds, both day and night, and all were thrown in those ditches ... and as soon as those ditches were filled, more were dug. And I, Agnolo di Tura, called

${ }^{20}$ Ziegler, The Black Death, 17.

${ }^{21}$ The term "Black Death" was first coined in Sweden in 1555, where it was called Swarta Döden, for the eruptions of black pustules, or buboes in the lymphatic regions of the body. 
the Fat, buried my five children with my own hands ... there was no one who wept for any death, for all awaited death. So many have died that everyone believes it is the end of the world. ${ }^{22}$

By 1348, the 'annus terribilis,' the most virulent year of the plague, Europeans, faced with a reality almost impossible to comprehend, began to seek answers to the ultimate cause of the Great Pestilence. Academics and those in the medical profession offered a host of theories as to why they were so afflicted. Between 1348 and 1350, university trained physicians and astrologers wrote at least twenty-four plague treatises. ${ }^{23}$ Historian John Kelly noted that, "some of the tracts took a big-picture view; others dispensed practical advice on how to stay healthy." ${ }^{24}$ Generally, the most common opinions as to the ultimate cause of the pestilence fell into two categories: that God sent the plague, punishing mankind for its sins and wickedness; and that the plague had an astrological, planetary origin. ${ }^{25}$

In October of 1348, King Philip VI of France requested the medical faculty at the University of Paris to find the cause of the Great Mortality. The faculty responded with the Compendium de epidemia per collegium facultatis medicorum parisius (The Plague Treatise of the Paris Medical Masters). The treatise pronounced that, "the first cause of this pestilence was and is [the] configuration of the heavens [which occurred] in 1345, at

\footnotetext{
${ }^{22}$ Agnolo di Tura del Grasso, Cronaca senese, ed. Alessandro Lisini and Fabio Iacometti, in Rerum Italicarum Scriptores, 15/6 (1931-37), 555-56. trans. Aubrey Threkeld, quoted in Aberth, The Black Death, 80-82.

${ }^{23}$ Kelly, The Great Mortality, 170. Some of the treatises commented on other environmental theories, such as earthquakes, comets, shooting stars, and frogs. See Aberth, The Black Death, 44-46.

${ }^{24}$ Kelly, The Great Mortality, 170. Most Islamic physicians wrote treatises centering on ways to avoid the disease, as it was punishable by death to ascribe the plague to God. For a typical example, see Abu Jafar Ahmad Ibn Khatimah, Description and Remedy for Escaping the Plague, quoted partially in Aberth, The Black Death, 55-63. See also Kelly, The Great Mortality, 170.

${ }^{25}$ Aberth, From the Brink of the Apocalypse, 113-14.
} 
one hour after noon on 20 March, [when] there was a major conjunction of three planets in Aquarius." $" 26$ The medical faculty further claimed, "this conjunction ... [was] the present cause of the ruinous corruption of the air. ${ }^{.27}$ The University of Paris' pronouncement was based in part upon Galen's Book of Fevers, which purported the theory of miasmatic air as the ultimate cause of disease. ${ }^{28}$ The theory held that the corrupted air would affect the humoral balance in persons, thus allowing them to become infected with the plague.

Historian Joseph Byrne remarked that as the 'annus terribilis,' continued, "the spread of disease from person to person ... threw a wedge between theory and observation regarding poisonous air. As the plague took its toll, it became clear that humoral balance seemed to play only a small role."29 New medical theories began to emerge. In contrast to the medical faculty at the University of Paris, who espoused belief in the miasmatic or atmospheric theory of disease contagion, doctors at the University of Montpellier "championed theories of human-to-human contagion, revolving around, respectively, the contaminating vehicles of poison and sight." ${ }^{\prime 30}$ The Spanish physician Alfonso de Córdoba, who was connected to the University of Montpellier, argued for the poison theory. In the Epistola et Regimen de Pestilentia (Letter and Regimen concerning the Pestilence), Córdoba offered that "experience teaches us that this pestilence does not proceed from some constellation [of the planets] nor as a consequence of any natural

${ }^{26}$ Kelly, The Great Mortality, 169. The three planets were Saturn, Jupiter, and Mars. See Aberth, From the Brink of the Apocalypse, 115, and Aberth, The Black Death, 41-45. ${ }^{27}$ Aberth, The Black Death, 41.

${ }^{28}$ Multiple sources treat the prevalence of Galenic medical theories in medieval medicine. For a broad overview, refer to Byrne, The Black Death, 42-44. See also Gottfried, The Black Death, 106-110.

${ }^{29}$ Byrne, The Black Death, 44.

${ }^{30}$ Aberth, The Black Death, 38. 
infection of the elements, but it proceeds out of a deep-seated malice through most subtle artifice that can be invented by a profoundly wicked mind."31 Tragically, the poison theory would lead to brutal pogroms and the murder of thousands of Jews throughout Europe, as many European Christians became convinced that Jews were conspiring to poison their city's wells. ${ }^{32}$

Eyesight was soon pronounced as another possible vector of the plague.

Florentine chronicler Matteo Villani observed that, "it seems that this pestiferous infection is caught by the sight and by the touch."33 Guy de Chauliac, a physician who practiced at Avignon during the first outbreak of the plague was another proponent of the belief in sight transmission. ${ }^{34}$ He noted in his Inventarium seu collectorium in parte cyrurgicali medicine, or the Grande Chirurgie, published in 1363, that the "mortality was so contagious, especially in those who were spitting up blood, that not only did one get it

${ }^{31}$ Alfonso de Córdoba, Epistola et Regimen de Pestilentia, quoted in Aberth, The Black Death, 45.

${ }^{32}$ For contemporary accounts of pogroms, see King Pedro IV of Aragon, Response to Jewish Pogrom of Tárrega, December 23, 1349; the Takkanoth (Accord) of Barcelona, September 1354; the Interrogation of the Jews of Savoy, September-October 1348; Mathias of Neuenburg, Chronicle, ca. 1349-1350; Konrad of Megenberg, Concerning the Mortality in Germany, ca. 1350; and Pope Clement VI, Sicut Judeis (Mandate to Protect the Jews), October 1, 1348. All of the above are quoted in Aberth, The Black Death, 139160.

${ }^{33}$ Matteo Villani, Cronica Universale, quoted in Byrne, The Black Death, 45. Matteo was continuing the chronicle of his brother, Giovanni Villani, who succumbed to the plague in 1348. Matteo himself would contract and die of the disease in 1363.

${ }^{34}$ Aberth, From the Brink of the Apocalypse, 121. Aberth noted that, "several authors, including no less an authority than Chauliac, believed that the plague could be transmitted by sight, literally, the "evil eye.'" As a side note, Chauliac contracted the bubonic form of the plague during the initial outbreak and was able to survive the disease. He believed that this was due to the fact that he lanced his pus-filled buboes: a treatment he would continue to argue for until his death in 1368. 
from another by living together, but also by looking at each other." ${ }^{35}$ Furthermore, an anonymous Montpellier doctor recorded in 1349 how looks could literally kill:

[T] he greater strength of this epidemic is such that it kills almost instantly, as soon as the airy spirit leaving the eyes of a sick man has struck the eye of a healthy bystander by looking at him, for then the poisonous nature passes from one eye to the other. And this occurs particularly when the sick are at the point of death. ${ }^{36}$

The belief that plague could be transmitted through direct eye contact persisted into the seventeenth century. William Shakespeare, in Act V, Scene II of Love's Labour's Lost, has the character Biron say, "Write 'Lord have mercy on us' on those three. They are infected, in their heart it lies, they have the plague, and caught it of your eyes. These lords are visited; you are not free, for the Lord's tokens on you do I see."37 The theory of the plague's transmission through eyesight, espoused by physicians such as

${ }^{35}$ Aberth, From the Brink of the Apocalypse, 64. For the Middle English version, originally titled the Inventarium seu collectorium in parte cyrurgicali medicine, see Guy De Chauliac, The Cyrugie of Guy De Chauliac Vol. 1, trans. and ed. Margaret S. Ogden (London: Early English Text Society, Oxford University Press, 1971), 155. De Chauliac recounted, "and it was of so grete contagiouste, and that was with spyttynge of blode, that one toke of it another, nought only in dwellynge but also in by holdynge, in so moche that the peple deide withoute seruauntes and thay were buryed withoute preostes." NB: I have had to substitute modern English letters for the Middle English letters "yogh," and "thorne."

${ }^{36}$ Míchon, Documents inéts sur la grande pesté, 46-52, quoted in Horrox, The Black Death, 182. See also Ziegler, The Black Death, 23. See also Aberth, The Black Death, 64. Aberth's translation varied in a small, but interesting manner. His citation of the anonymous physician read, that the "plague can kill almost instantly, as when an aerial spirit leaves the eyes of a sick person and strikes the eyes of a healthy man attending him, especially when he is looking at the sick man in his death throes."

${ }^{37}$ Hibbard, The Oxford Shakespeare, 211. Hibbard included notes on the text cited above. He offered that 'Lord have mercy on us' "had to be written on the door of every house affected by the plague to serve as a warning to all who might wish to enter. They were also, of course, a genuine prayer, since an outbreak of plague was regarded as God's punishment of the wicked." Furthermore, 'the Lord's tokens' were "plague spots which appeared on the patient's body in the final stages of the disease." Hibbard unfortunately did not discuss eyesight transmission. 
Guy de Chauliac, and the anonymous Montpellier physician, was based upon the ancient

belief of the evil eye, and its very real potential to cause deadly harm. Elworthy noted,

belief in the evil eye is probably the oldest and most widespread of superstitions. ... it was common throughout Europe in the Middle Ages; and during the worst period of the Black Death it was generally supposed that the disease was communicated by a glance from the eyes of a sick person. ... in England at the time of the Black Death ... even a glance from the sick man's distorted eyes was sufficient to give the infection to those on whom it fell." ${ }^{38}$

Following ancient Greek and Roman beliefs concerning the evil eye, numerous theories about how to avoid or divert its gaze were prevalent in late medieval society. It was generally held that to deflect the potentially harmful look, it was considered essential to attract it toward something striking which would, in essence, absorb the evil, much like a modern Kevlar vest. ${ }^{39}$ The most efficacious apotropaic objects were thought to be indecent or obscene in nature, as,

nothing, as is well known of all ages attracts or excites curiosity as obscenity and indecency; and hence of all amulets, those partaking of this character were the most potent, and therefore the most used. Anything strange, odd, or uncommon, as likely to attract the eye, was considered most effectual, and consequently the objects viewed as protective against it were almost infinite in number ... in [protective] amulets ... the commonest of all objects was the phallus. ${ }^{, 40}$

As the broader facts concerning the plague have been discussed, as well as the contemporary theories of disease contagion and transmission, an examination of the state of medieval medicine is in order. Humoralism, the predominant medieval medical theory

\footnotetext{
${ }^{38}$ Elworthy, The Evil Eye, ix.

${ }^{39}$ Ibid., xi. Elworthy added that "it was believed that the first glance of the evil eye was the most fatal, and therefore it was of the utmost importance that any object intended to protect against its influence should be such as should attract the first or fatal stroke; for it was just as firmly held, that whatever diverted it for the moment from the person or animal liable to injury, absorbed and so destroyed its effect." (143).

${ }^{40}$ Elworthy, The Evil Eye, 148.
} 
of disease, was founded by Hippocrates and reached the West through the Roman physician Galen and Arabic physicians, including Avicenna. Until the advent of the Germ Theory in the nineteenth century, Humoralism would dominate the medical practice. Humoral theory holds that the four bodily humors, black bile, yellow bile, blood, and phlegm, were affected by a person's diet, activity, and environment. Each of the humors was associated with one of the four elements, an internal organ, as well as temperature and moisture. For instance, black bile was connected to the spleen and the Earth, and was considered cold and dry. Yellow bile, associated with the liver and Fire, was hot and dry. Blood, connected to the heart and Air, was hot and moist. Phlegm, associated with the brain and Water, was cold and moist. Robert Gottfried noted that "when one's bodily humors were in equilibrium, one was in good health; this was called Eukrasia. When one's humors were not in balance, one was sick, a condition called Dyskrasia, and it was the physician's job to find the means to restore the proper balance." $" 41$

During the medieval period, the human body was read as a text, and physical appearances of the body reflected one's overall health. Bryon Grigsby noted that, "an unhealthy body represented an imbalance, usually identified through a change or sign on the outside of the body, either on the skin or from an excreted fluid, such as urine. ${ }^{, 42}$ Robert Gottfried added that doctors "based their ideas on theory rather than direct, clinical observation and experience.... Consequently, they were poor anatomists,

${ }^{41}$ Gottfried, The Black Death, 106. See also Jonathan Sumption, The Age of Pilgrimage: The Medieval Journey to God (1975; reprint, Mahwah, NJ.: HiddenSpring, 2003), 102. ${ }^{42}$ Bryon Grigsby, "Medical Misconceptions," in Misconceptions About the Middle Ages, eds. Stephen J. Harris, and Bryon L. Grigsby (New York: Routledge, 2008), 143. 
pathologists, and epidemiologists, and were able to do little to fight the plague. ${ }^{, 43}$

Gottfried's observation is certainly true on many levels. There was indeed little medieval doctors could do to combat the plague. There is, however, a flaw within his statement that of an anachronistic comparison between medieval and modern medicine. This false comparison skews the light in which medieval medical practices are viewed and detracts from the fact that medieval physicians approached "medicine as a cumulative process in which one studied medical authorities and appended or altered the authoritative corpus through clinical experience. ${ }^{, 44}$ Medieval historian Stephen Harris cogently remarked that, "given the knowledge they were able to accumulate, their responses to disease and health were both rational and often effective., ${ }^{, 45}$

Based upon the development of medieval medical scholarship, current historians are attempting to view medieval medicine in a new light, moving past the biased belief that medieval medicine was at its best, when compared to modern medicine, laughable. Historian Bryon Grigsby is one such scholar, and he outlined modern misconceptions about medieval medicine. Grigsby convincingly argued that, rather than approach the medieval medical community from a positivistic framework in which the medieval doctor is a primitive reflection of our modern doctor ... historians [should adopt] a social constructionist viewpoint in which they attempt to evaluate the medieval medical community as part of a larger social system. ... Medieval medicine is neither a precursor to our modern medicine nor a simplistic, primitive system. Rather, it is an extremely learned theory that makes sense when one considers the information doctors of the period had to rely on. ${ }^{46}$

\footnotetext{
${ }^{43}$ Gottfried, The Black Death, 106.

44 Grigsby, "Medical Misconceptions," 142-143.

${ }^{45}$ Stephen J. Harris, introduction to Misconceptions About the Middle Ages, eds. Stephen J. Harris, and Bryon Grigsby (New York: Routledge, 2008), 18.

${ }^{46}$ Grigsby, "Medical Misconceptions," 142-143.
} 
It should also be remembered, as Harris argued, "medieval medicine offered medieval people an image and rationale of the inner workings of their bodies ... [and doctors] prescribed a balanced disposition, good diet, and a holistic approach. ${ }^{, 47}$

Contemporary medieval sources, however, record the wide spread belief in the inefficacy of physicians to combat the plague. Indeed, distrust in the medical profession was not a medieval peculiarity. Pliny the Elder averred, "and yet to speak a truth, there are no lies dearer sold or more dangerous than those which proceed out of a physician's mouth. ... they learn their skill by endangering our lives: and to make to make proof and experiments of their medicine, they care not to kill us. ${ }^{, 48}$ Giovanni Boccaccio, in the oftquoted introduction to The Decameron, wrote, "neither a doctor's advice nor the strength of medicine could do anything to cure this illness; on the contrary, either the nature of the illness was such that it afforded no cure, or else the doctors were so ignorant that they did not recognize its cause. ${ }^{, 49}$

Medical treatment theories varied as widely as the theories of the plague's ultimate cause. An examination of contemporary late medieval medical prescriptions for preventatives against the plague highlights the varying opinions, as well as the general impotence of the medical profession in the face of the pandemic. John Aberth noted that for contemporaries, urban doctors "generally did not fare well at the hands of medieval chroniclers of the Black Death, who accused them of cowardice, impotence, and, above

\footnotetext{
${ }^{47}$ Harris, Misconceptions, 18.

${ }^{48}$ Pliny the Elder, Natural History, Books 28-37, trans. Philemon Holland (Carbondale, IL.: Southern Illinois University Press, 1962), 296.

${ }^{49}$ Giovanni Boccaccio, The Decameron, trans. Mark Musa, and Peter Bondanella (New York: Penguin Books, 1982), 8. The Decameron includes many humorous stories about the inefficiency and impotency about medieval physicians.
} 
all, greed." ${ }^{50}$ It is only through the gift of hindsight that we can understand why the common populace distrusted the medical profession. Doctors were, however, as Grigsby reminds us, conducting medicine to the best of their abilities based upon the knowledge they had access to. Moreover, many physicians contracted or died of the plague, including Guy de Chauliac and Gentile da Foligno. To modern readers, many of their "cures" appear more likely to have caused more harm than good, while some, such as fleeing infected areas, make perfect sense and likely saved lives. The following is a discussion on the palliative prescriptions used by contemporary doctors. It will become apparent that many contemporary remedies and preventatives against the Great Mortality address maintaining or balancing the four humors through the varying means of diet, physical activity, medicines, and the physical environment.

Proponents of the miasmatic theory of contagion suggested physical removal from infected areas, if possible, in order to escape the contaminated air. Alfonso de Córdoba argued that "the best remedy is this: to flee the plague, because the plague does not follow the fugitive." ${ }^{51}$ Giovanni Boccaccio's characters in The Decameron provide a famous example of this preventative measure. ${ }^{52}$ Most people, however, could not afford

\footnotetext{
${ }^{50}$ Aberth, The Black Death, 37. Aberth quoted Florentine Matteo Villani, who lamented, "for this pestilential infirmity [of 1348], doctors from every part of the world had no good remedy or effective cure, neither through natural philosophy, medicine [physic], or the art of astrology. To gain money some went visiting and dispensing their remedies, but these only demonstrated through their patients' death that their art was nonsense and false." (Matteo Villani, Chronica, ed. Guiseppe Porta, 2 vols. (Parma: Fondazione Pietro Bembo, 1995), 1:13.

${ }^{51}$ De Córdoba, Letter and Regimen, quoted in Aberth, The Black Death, 46.

${ }^{52}$ Aberth, From the Brink of the Apocalypse, 121. Aberth noted that it is likely that Boccaccio's protagonists were fleeing "accidents of the soul,"... [and] taking their minds off the illness could be a matter of life or death." The "accidents of the soul" theory of contagion held that people could literally imagine themselves into contracting
} 
to uproot themselves and their families, or they simply had no place to escape the plague, as the plague seemed to be everywhere.

John Aberth noted that to combat miasmatic air, "the most common antidote[s] recommended ... were aromatics, such as sweet-smelling herbs, flowers, and perfumes, that were to be sprinkled in the house or carried under the nose. ${ }^{.53}$ In one of the earliest plague treatises, from April 1348, the Regiment de preservacio a epidimia o pestilencia e mortaldats (Regimen of Protection against Epidemics or Pestilence and Mortality), the Spanish physician Jacme d'Agramont prescribed the use of aromatics. ${ }^{54}$ D'Agramont recommended that "one should make fires in the room of good firewood, such as rosemary and myrtle, or of cypress ... or of juniper ... or of lavender. ${ }^{, 55}$ If one could not obtain these materials, he noted,

the common folk ... can make fire in their huts and in their chambers of rosemary and juniper, and make fumigations of incense and myrrh or of other things cheaply to be had such as "cimiama" [cumin] or "herb of thur" [frankincense]. And I will say that the fire alone can effectively rectify air putrid in its substance. ... it must be said that it is most beneficial to sprinkle the floor of the room with rose water and vinegar. ${ }^{56}$

D'Agramont also prescribed avoiding exercise, as this would cause "much air which is foul and poisoned to be drawn to the heart. ${ }^{, 57}$ Muslim physicians were much of the same mind, and Ibn Khatima noted that persons "should be as quiet as possible. If

the plague. Medieval physicians, including the Carmelite friar Jean de Venette, "believed that fearful thoughts about the plague would inevitably come true." (121).

${ }_{53}$ Aberth, From the Brink of the Apocalypse, 115.

${ }^{54}$ Jacme D'Agramont, "Regiment de preservacio a epidimia o pestilencia e mortaldats," trans. M. L. Duran-Reynals, and C. E. A. Winslow, Bulletin of the History of Medicine 23 (1949): 75, 78-85, quoted in Aberth, The Black Death, 51-55. See also Gentile da Foligno, Consilium, quoted in Aberth, The Black Death, 49.

${ }^{55}$ D'Agramont, Regiment, quoted in Aberth, The Black Death, 52.

${ }^{56}$ D'Agramont, Regiment, quoted in Aberth, The Black Death, 52. See also Ibn Khatima, A Description and Remedy, quoted in Aberth, The Black Death, 55-63.

${ }^{57}$ D'Agramont, Regiment, quoted in Aberth, The Black Death, 52. 
one needs to move, it should be moderate in order to not strain oneself or cause heavy breathing. The natural heat [of the body] should not be increased so that a person would be forced to breath more than normal, and thus has to inhale more bad air."

Physicians and treatise writers also concerned themselves with the types of foods that should be eaten or avoided, as these, due to their inherent nature, could adversely or positively affect one's humoral balance. The Perugian physician Gentile da Foligno recorded in his Consilium contra Pestilentiam (Casebook against the Pestilence) a detailed example of a dietary guide. He offered, men should appropriately consume fine food and drink in measured quantities and of suitable quality ... but fish is to be avoided, for on no account should men consume it. Moreover, concerning lettuce, it is advised that if it has been left out in the cold, men should by no means consume it, but that when its color comes back, it is safe to eat. Furthermore, from among various foods, we recommend the eating of good meat, including fowl, chicken, and starlings. But of beef, [we recommend] gelded cows and lactating goats and calves, as well as young pork. Also, we recommend bread carefully prepared and select wines, so that men may live in good cheer as they give vent to their fear. ${ }^{59}$

Jacme d'Agramont also offered a detailed prescriptive diet, one that outlines in a clearer manner, the concern for certain foods' ability to cause humoral imbalance. He noted, man should eat and drink as little as possible. Especially, drinking must be temperate and it is advisable that he control his thirst. Also one should use in all foods much vinegar, sorrel, juice of oranges and of lemons and other acid things which are most beneficial. Clear fresh wine is better than sweet wine, because wine that contains sweetness putrefies more easily and has great tendency to turn into bile. Also one must avoid in such times birds that feed near stagnant waters, such as water hens, and geese, and ducks and other animals that have naturally humid flesh, such as suckling pigs and lambs. Also, in such times slimy fishes such as lampreys and eels and rapacious fishes, such as dolphin,

${ }^{58}$ Ibn Khatima, A Description and Remedy, quoted in Aberth, The Black Death, 57.

${ }^{59}$ Gentile da Foligno, Consilium contra Pestilentiam, quoted in Aberth, The Black Death, 48. Foligno would eventually contract, and subsequently die of the plague on June 18, 1348 . 
shark, tunny-fish, and similar fishes should be forbidden. Especially to be avoided, aside from the above-mentioned fishes, are any others when they are rotten and smelling badly. ${ }^{60}$

Bloodletting was another popular preventative measure that was believed to restore balance to the four humors. Ibn Khatima noted, one shouldn't be too fearful or hesitant. It is the best way to maintain one's health during this calamity! ... it should be done two or three times a day. ... and I've seen the benefits during the reign of plague. I have seen people who prophylactically gave up to 8 pounds of blood; most people gave about $5 .{ }^{3,61}$

Jacme D'Agramont records a more moderate amount to be bled when he recorded that one could "bleed the median vein or some other on order to withdraw blood, 3 or 4 ounces, more or less according to the condition of the person. ${ }^{.62}$

Physicians who followed the poison theory, rather than the humoral or miasmatic theory, were staunch proponents of taking theriacs or electuaries. Theriacs were compounds of dozens of ingredients, snakeskin being the most important, and were "thought to neutralize the deadly poison inside a sick person." ${ }^{63}$ Typically, theriacs were taken in the form of syrups or treacles, and included ingredients such as bone from the heart of a stag, Armenian clay, metals and gems such as gold, silver, pearls and emeralds, and exotic plant extracts from aloe, myrrh and saffron. Gentile da Foligno prescribed that "men should take at least two or three times a week until the end of May [1348] the best theriac or antidote. ... But the theriac ought to have been already aged for one year, and because all men can not obtain a theriac, it is recommended that poor men consume leeks

${ }^{60}$ D'Agramont, Regimen of Protection, quoted in Aberth, The Black Death, 52-53.

${ }^{61}$ Ibn Khatima, Description and Remedy, quoted in Aberth, The Black Death, 58.

${ }^{62}$ D'Agramont, Regimen of Protection, quoted in Aberth, The Black Death, 53-54.

${ }^{63}$ Aberth, The Black Death, 49. See also Aberth, From the Brink of the Apocalypse, 116117. 
or holy water and scabiosa [a kind of plant] or scallions. ${ }^{.64}$ Guy de Chauliac recorded that during the second major outbreak in 1361 , he "toke therof as of triacle, and I was preserued by Goddes grace. ${ }^{.65}$

Guy de Chauliac contracted bubonic plague in 1348 and was able to nurse himself back to health. ${ }^{66}$ He believed that this was due to the practice of lancing and draining the pus from the buboes, followed by cauterization. In his Cyrugie, Chauliac recorded, in the cure, blode lastes [blood lettings] and euacuacions were made and cordial syrups and letuaries [theriacs]. And vtter apostemes [buboes] were matured with fyges with oynouns sodden and stamped and medled with soure dowh and with bottre. And after, they were opened and they were heled with the curacion of vlcers. Felons were ventoused [opened] and garsed [lanced] and cauterised. ${ }^{67}$

Ibn Khatima also prescribed poultices to "mature" the buboes, and once they had filled with pus he advised, "to resolve them surgically." ${ }^{.68}$ In rare instances, this treatment seemed to have worked, but as the bubonic form of the plague generally has a $60 \%$ lethality rate, the patients who survived lancing and cauterizing might have recovered on their own. In an obviously desperate attempt to find a remedy, one prescription held that people should bathe in their own urine, and drink the pus from lanced buboes so that they could "vaccinate" themselves against the plague. ${ }^{69}$ As unpalatable as this treatment sounds, there is undoubtedly something very insightful about the theory behind the prescription. Moreover, as Aberth remarked, "there is something of the magician, the

${ }^{64}$ Gentile da Foligno, Consilium, quoted in Aberth, The Black Death, 49.

${ }^{65}$ Ogden, Cyrugie of Guy De Chauliac, 158.

${ }^{66}$ Surviving an infection of the plague in the first epidemic, as we now know, is what "preserued" Chauliac in 1361, not a theriac. ${ }^{67}$ Ogden, Cyrugie of Guy De Chauliac, 157.

${ }^{68}$ Aberth, The Black Death, 62.

${ }^{69}$ Aberth, From the Brink of the Apocalypse, 116. Unfortunately, Aberth did not cite the source of this preventative measure. 
alchemist, the shaman in these medical "experts" and their desperate remedies for the plague." 70

It is with the examination of the prescriptions in the Liber de Diversis Medicinis, written between 1422 and 1453 , that one can see both the learned, scholarly approach to medicine, as well as more popular folk medical treatments. The Liber de Diversis Medicinis, contained in the Thornton Manuscript, is a late medieval compendium of recipes, or, prescriptions for curing various diseases and ailments. The recipes range from the simple to the complex, and like most medicine of the time, they have their foundation in the Hippocratic and Galenic theory of the four humors, and how to restore an imbalance. Margaret Ogden noted of the recipes, "a significant development was the gradual Christianization of the pagan charms and magical cures. ${ }^{, 71}$ As it will be seen below, however, the 'Christianization' was only partially complete by the mid-fifteenth century, and many of the 'pagan' cures had only been lightly veneered with Latin phrases.

As Europe was still suffering epidemics of the plague in the mid-fifteenth century, the Thornton Manuscript contains several prescriptions and remedies to treat the disease. The treatments for the plague differed little from the remedies discussed above from physicians such as Guy de Chauliac and Ibn Khatima, and the author of the manuscript is a direct successor of the earlier, learned writers. In the section "Here bygynnes medcynes for the pestilence" the physician noted that if the "venom of the blode ... passe nott owte bi blode latynge, it festers in some place and castes a man in-to an agewe and makes a

\footnotetext{
${ }^{70}$ Aberth, From the Brink of the Apocalypse, 117-118.

${ }^{71}$ The 'Liber de Diversis Medicinis' in the Thornton Manuscript, ed. Margaret Sinclair Ogden (London: Early English Text Society; Oxford University Press, 1938; revised reprint, 1969), xxi.
} 
boche or a kille [ulcer/boil] in some place., ${ }^{, 72}$ Once bloodletting failed to work and buboes formed, he declared that it

then is gude to hafe water stilled of thiese foure herbis: detony, pympernole, tormentill and scabyous, for thiese are gud medcyns bothe in sekenes ... and also, whils a man is in this euyll [evil], he schulde be dietide mesurably. For ... he schuld not ett gret flesche, bot chekyns sothen with water or litill fisches of fresche water rostede and ett tham with vynagre. ${ }^{73}$

Following Chauliac's and Ibn Khatima's belief in 'maturing' the buboes, the author of the Thornton Manuscript offered twelve recipes to "brek kyles," (buboes) two of which are recorded below. To 'mature' the buboes, and make them burst, he noted,

tak baynewort jus a sawcerfull and als mekill (also take) of a rede cowe newe mylke and flour of whete and make it in a plaster and lay it alle warm ther-on and it sal brek it ... or take wormot and smalache [herbs] ana and swyn gres [pig grease], als mekill of the herbes, and bray all to-gedir and do it on a clout and lay it on ther felon or appostym and it sal drawe owt the felon or the appostym, and all the filthe and hele it with-owtten any entrete.... And a man be venomed, it will putt owt the venom ... and who so dredis for this sekenes ... thurgh the grace of God he sal be helpede of this sekenes. ${ }^{74}$

Other recipes or prescriptions in the Liber de Diversis Medicinis evince ties to folk medical practices, with roots heavily founded in the pagan past. As Ogden noted, however, many of the following charms discussed below have been, at least nominally, Christianized. The recipes below are included to help bridge the gap between urban, learned medicine, to which few had access, and folk practices that the majority of Europeans had access to, during the late medieval and early modern periods. It will be seen that many of the remedies listed below have a magical, charm-like quality that lies

${ }^{72}$ Ogden, Liber Medicinis, 51-52. The boils, or buboes, would appear under the arms, in the groin, behind the ears, or on the throat.

${ }^{73}$ Ogden, Liber Medicinis, 53.

${ }^{74}$ Ibid., 54. 
in stark contrast to those already discussed. For instance, to help bring on a woman's

labor, the author of the Thornton Manuscript recorded,

Here bygynnes a charme for trauellyng of childe ... occeanum age, surge, rumpe and explica moras. Write this charme and bynde it to hir knee righte with-in and, alsone als scho es delyuered, tak it a-waye. ... An other charme. Note bene optime ... Beaté Anna genuit sanctam Mariam matrem Domini nostri Ihesu Christi and Sancta Maria genuit Christum filium Dei nunciante Gabriele arcangelo. Peripsam [sic] natiuitatem credo ego quia omnis christianus amorte and [sic] ab omni periculo potest esse liberatus. Sancta Maria, Dei genitrix, and [sic] omnes apostolic and omnes martires and [sic] omnes sancti confessores and [sic] omnes sancta virgins intercedant pro famula Dei. N. Amen. Tak and write thir wordis in butter or in chese and gare hir ett it: Sator arepotenet opera rotas. $^{75}$

Another charm in the Thornton Manuscript listed how to make "a woman say what thu askes hir." To do so, one was to "tak a stane that is called agagate [agate] and lay it on hir lefte pape [breast], when scho slepis, that scho wiet [know] not, and, if the stane by gude, all that thu askes hir sall scho say the, what euer scho hase done." 76

The examples from the Thornton Manuscript provide, albeit briefly, a view into the syncretism of Christian and pagan medical practices during the late medieval period. At this point, we must back track a bit, so that the discussion can turn to a brief analysis of popular lay religion, with its retention of pre-Christian, pagan practices and magical beliefs. Indeed, Christianity itself is a hybrid, syncretized religion, composed of various pagan aspects, Roman Mystery religions, and Judaic beliefs. ${ }^{77}$ Moreover, the liturgy and

${ }^{75}$ Ibid., 56-57.

${ }^{76}$ Ibid., 57-58. The recipes that have been highlighted in this discussion are but a few of the hundreds found in the Thornton Manuscript.

${ }^{77}$ It should be noted that the above is a highly contested claim, though this is not the forum to continue the discussion. For a foundational book on the subject, see Keith Thomas, Religion and the Decline of Magic (New York: Charles Scribner's Sons, 1971). See also Aron Gurevich, Medieval Popular Culture: Problems of Belief and Perception, trans. János M. Bak and Paul A. Hollingsworth (Cambridge: Cambridge University Press, 
rituals of Catholicism - the process of transubstantiation for one example - retain magical aspects that helped to blend the distinction between sanctioned, church-approved magic, and popular lay magic. Furthermore, during the late medieval period, the mystical and the magical could be seen as interchangeable. Historian Keith Thomas noted that the "medieval Church ... acted as a repository of supernatural power." ${ }^{, 78}$ For instance, there were rituals to bless homes, cattle and crops; priests, holy water, and the cross had magical powers, and the Church encouraged the sale of talismans and amulets at a myriad of pilgrimage destinations. ${ }^{79}$ Historian Richard Kieckhefer argued that religion and magic were not in binary opposition, and that "magic [was] connected in multiple ways with mainstream religious practice. ${ }^{, 80}$

For many historians in the past, however, the Middle Ages was known as an 'Age of Faith.' Universal Catholicism in the Western world was purported to have reigned supreme. According to this viewpoint, entire populations of Europeans lived pious and faithful lives, with the Church and its rituals and tenets followed unquestioningly. While the Catholic Church did in many ways reign supreme in the West, and was able to exert power and authority over many aspects of life for well over one thousand years, the exact nature of religion's role in the lives of everyday, common people is more ambiguous, and not so easily reconstructed.

Modern historians of religion and lay beliefs now give voice to the ambivalence surrounding many of the practices from the medieval period. For example, John Arnold

1988). See also Richard Kieckhefer, Magic in the Middle Ages (Cambridge: Cambridge University Press, 1989), 42-44.

${ }^{78}$ Thomas, Religion and the Decline of Magic, 32.

${ }^{79}$ Ibid., 29-30. See also Kieckhefer, Magic in the Middle Ages, 75-77.

${ }^{80}$ Kieckhefer, Magic in the Middle Ages, $\mathrm{x}-\mathrm{xii}$. 
suggested that "medieval lay piety was many things: excitable, lazy, repressive, accepting, gendered, hierarchical, socially leveling, deeply devout and deeply skeptical which is to say, there was no one medieval lay faith but a spectrum of faith, belief and unbelief." ${ }^{, 81}$ Moreover, as historians Richard Kieckhefer and Keith Thomas argue, medieval Catholicism retained many magical, pre-Christian aspects that are still central to the religion, and this allowed for a certain amount of lateral movement within medieval lay piety. In other words, as Thomas noted, "the hold of organised religion upon the people was never so complete as to leave no room for rival systems of belief." ${ }^{, 82}$ In "The Age of Faith: Everyone in the Middle Ages Believed in God" Peter Dendle argued that beginning in the Renaissance, people began to view the Middle Ages as superstitious, overly religious, and incredulous. ${ }^{83}$ The trend to view the Middle Ages in this light is compounded by the fact that the majority of surviving documents from the period are by clerical authors. This skews the perceptions of the level of medieval lay religiosity, as the documents do not speak of what the common person actually believed and practiced. Indeed, how can one reconstruct the religious opinions of the general population, "the countless illiterate villagers and peasants whose knowledge of religion essentially started and ended at the local pulpit [?] $]^{\prime 84}$ Dendle offered a fundamentally important observation when he argued, "the written records of the Middle Ages generally

${ }^{81}$ John H. Arnold, Belief and Unbelief in Medieval Europe (London: Hodder Education, 2005), 230.

${ }^{82}$ Thomas, Religion and the Decline of Magic, 173.

${ }^{83}$ Peter Dendle. "The Age of Faith: Everyone in the Middle Ages Believed in God," in Misconceptions About the Middle Ages, eds. Stephen J. Harris, and Bryon L. Grigsby (New York: Routledge, 2008), 49. Dendle added that categorizing the period as 'superstitious' is generally "imposed by one sector of society on another sector of that society to belittle and demean it." (118).

${ }^{84}$ Dendle, "The Age of Faith," 51. 
insist on the existence, the omnipotence, and the benevolence of a Creator Diety. This very insistence, however, should give pause for thought: the truly unquestioned premises within a belief system ... necessarily remain unspoken. ${ }^{.85}$ Furthermore, he added, "the articulation of a position is only meaningful in the face of doubt or potential dissent. Seen in this light, the repeated assertions of God's existence, justice, and goodness imply a society deeply anxious about those issues. ${ }^{, 86}$ In a society already 'deeply anxious' about religious issues, one must then factor in the Great Pestilence that began in 1347. During the ensuing catastrophic health crisis, it makes perfect sense that people would have turned to any remedy, practice, or belief that they hoped could provide protection or prevention, whether it was officially sanctioned by the Church or not. Historian Aron Gurevich observed that during this period,

danger threatened from every quarter, and precautionary measures ... were of great importance.... Whatever the origins and parallels of these practices may be, the significant thing about them is their extraordinary ... vitality in a period which is usually regarded as completely controlled by Christian spirituality. ${ }^{87}$

It is important to remember as well, that many of the medical treatments discussed so far, including the various plague remedies and preventatives, were only available for urban elites, fellow academics, and the aristocratic or clerical sectors of late medieval society. The common men and women, the majority of whom dwelled in rural agricultural settings, or smaller towns, relied mainly on herb doctors, charm-healers and the 'wise women' of their areas, as they had absolutely no physical access to, or the ability to pay, the learned, scholarly medical professionals. Historian Keith Thomas

\footnotetext{
85 Ibid., 49.

86 Ibid.

${ }^{87}$ Gurevich, Medieval Popular Culture, 89-90.
} 
offered that medicine began at home, as the "the impact of organized medicine upon the lower reaches of the population were seldom more than superficial. ${ }^{988}$ Historian Jonathan Sumption offered that, "in an earlier age, ill-equipped to understand the mysteries of sickness and health, it would be surprising if people did not put their faith in unorthodox medicine and magic rituals. ${ }^{, 89}$ Furthermore, Dendle astutely observed that there are often deep-seated psychological motives for beliefs that are, on the face of things, irrational: for instance, the perpetuation and enactment of ritual lore can give people a psychological sense of comfort $\ldots$ and can relieve anxiety by providing a sense of control over circumstances that are in fact beyond all control. ${ }^{90}$

Concerning the eruption of the Black Death in 1347, it is hard not to view the next one hundred and fifty years as 'circumstances that were in fact beyond all control.' At the same time, the previous observation provides the perfect segue into the discussion of the 'irrational' beliefs and practices which the common late medieval man and woman employed to combat the plague.

${ }^{88}$ Thomas, Religion and the Decline of Magic, 12.

${ }^{89}$ Sumption, The Medieval Journey to God, 121. See also Valerie I. J. Flint, The Rise of Magic in Early Medieval Europe (Princeton: Princeton University Press, 1991).

${ }^{90}$ Peter Dendle, "The Middle Ages Were a Superstitious Time," in Misconceptions About the Middle Ages, eds. Stephen J. Harris, and Bryon L. Grigsby (New York: Routledge, 2008), 121. 


\section{CHAPTER IV}

\section{THE BAWDY BADGES: AN INDECENT FACE FOR THE CURE}

Following Arthur Forgeais' 1848 discovery of the tokens recovered from the river silt of the Seine, badges of a seemingly erotic nature began to turn up across the European countries of England, France, and especially the Netherlands. The nineteenthcentury amateur archaeologists, farmers, and rivermen who found such objects understandably did not know what to make of them. Many wondered if they were not perhaps ancient artifacts from the period of Roman occupation that each of countries mentioned above at one time or another experienced. Soon, however, it became apparent that they were indeed medieval objects, as the bawdy amulets were found alongside datable, and unquestionably medieval artifacts; namely coins and religious pilgrims' badges, or as they are also known, signs, tokens, and amulets. ${ }^{1}$

Indeed, as it will be discussed below, the bawdy badges are inextricably linked to medieval pilgrims' souvenirs. Given this assertion, it is necessary to place these enigmatic objects within the broader framework of medieval religious devotionalia, as

\footnotetext{
${ }^{1}$ When possible, modern archaeologists date the waterfront deposits in England, France, and the Netherlands using dendrochronology, coins, and pottery sherds. See Spencer, Pilgrim Souvenirs, 25. See also Kieckhefer, Magic in the Middle Ages, 75. Kieckhefer noted that "herbs, animal remedies and charms were used mostly to cure diseases that had already set it. Amulets, on the other hand, were typically meant as protective devices. . . .Amulets served psychological purposes somewhat more than physical ones . . they could ward off disease, to be sure, but more often they protected their bearers against the attacks of visible and invisible enemies."
} 
well as the curative function of pilgrimage. Furthermore, pilgrimage amulets of both a religious as well as a secular nature are related in a meaningful way to medieval medical and palliative traditions. Learned medicine and magic were not necessarily separate categories during the late medieval period, and in attempting to view medicine as an unrelated entity, different from that of magical healing - as the amulets of both natures were intended to function - is an erroneous paradigm. ${ }^{2}$

The analysis will begin with a brief introduction into the history of religious pilgrimage souvenirs. In England, Brian Spencer remarked "for well over 300 years discarded souvenirs from Canterbury ... had been disappearing into oblivion in and beside the Thames at London.... some badges ... [were] deliberately thrown into the river, perhaps as a propitiatory gesture, their owners instinctively adopting superstitious practices performed by travelers in later as well as earlier times." ${ }^{, 3}$ Suspended, in many instances for over 500 years, in river silt, an ideal, anaerobic environment that preserves metalwork, literally tens of thousands of religious pilgrims' badges were discovered by the Museum of London's archaeological staff between 1972-1992. ${ }^{4}$ The majority of the excavations in London were conducted in foreshore deposits or in dumps of organic refuse up to three meters thick. Between 1150-1450 CE, these refuse dumps were "used behind a succession of new wharves to form new land."

\footnotetext{
${ }^{2}$ For an insightful discussion of this assertion, see Gurevich, Medieval Popular Culture, 62. Gurevich observed, "priests condemned the remedies of soothsayers and sorcerers for healing the sick but agreed that dust from the altar or a pouch of earth taken from a saint's grave possessed healing properties. Magic was admitted by the church into its practices and rituals; the border dividing Christian magic from what was condemned as maleficum was indeffinate and surely unclear to the parishioners."

${ }^{3}$ Spencer, Pilgrim Souvenirs, 24.

${ }^{4}$ Ibid.

${ }^{5}$ Ibid.
} 
reclamation practices were employed in France along the banks of the Seine, and in the Netherlands along the Schelde Estuary during the period of 1150-1450 CE. Modern archaeological excavations have brought to light similar quantities of religious pilgrims' souvenirs in France and the Netherlands, deposited into the waterways in a similar manner as found in England.

Throughout the entire medieval period, and especially after the tenth century CE, devotional pilgrimage to shrines and churches reached a fevered status. Some pilgrims undoubtedly went for the chance at adventure, escaping their monotonous lives. Others undertook a pilgrimage for the remission of sins committed. While others, and arguably the majority, went on a pilgrimage, however brief or extended in duration, to seek a miraculous medical cure. Hundreds of localities across the Continent and England were associated with a particular saint, and people in droves sought various cures promised by the relics of the saint housed within a particular shrine or church. Soon the Church, as well as the local citizens of communities that contained popular pilgrimage destinations, realized the economic potential the pilgrims provided. Simply put, pilgrims needed to eat, needed places to sleep, and much like tourists today, wanted souvenirs of their travels to take home. Historian Diana Webb observed that "the development of markets in the vicinity of pilgrimage churches ... was a parallel and inseparable phenomenon. ... [And] another indication of . . . an expanding society is the manufacture and marketing of 'souvenirs' of pilgrimage."

Pilgrims' souvenirs generally took the form of amulets depicting the saint of the shrine, or of the saint's popular attributes. For instance, pilgrims to Santiago de

\footnotetext{
${ }^{6}$ Webb, Medieval Pilgrimage, 33-35.
} 
Compostella, one of the most venerated pilgrim destinations of the entire medieval period, bought in mass quantities scallop shell amulets that would be worn around the neck or sewn onto the outer garments. ${ }^{7}$ Pilgrims to Thomas Beckett's shrine at Canterbury bought either amulets depicting an image of the saint, or small ampullae that could be filled with holy water that had washed his shrine. ${ }^{8}$ Much like collectors of souvenir pins today, pilgrims would showcase their travels by the badges they had amassed on pilgrimage. On a detail from a painted panel of a Flemish altarpiece dating to $1490 \mathrm{CE}$, one can see the popular medieval practice of pilgrims wearing their badges on their hats and outer garments (Figure 14).

As it was discussed in Chapter 2, it needs to be remembered that it was common, and justified in many respects during the medieval period, to view earthly medicine as inadequate and to believe that only through God, or another saintly mediator, could one's illness be alleviated. ${ }^{9}$ Therefore, as Carol Rawcliffe averred, "pilgrimage was comfortably absorbed into an ancient, pre-Christian tradition of folk-healing through the use of amulets, incantations and sacred objects, which the medieval Church attempted to harness for its own purposes of social control." ${ }^{, 10}$ Indeed, the Church played a fundamental role in the creation and sale of these 'signs,' as contemporaries knew them.

\footnotetext{
${ }^{7}$ In fact, a twelfth century 'Pilgrim's Guide' to Santiago de Compostella provides the earliest reference to souvenir markets in front of churches along the pilgrimage routes to the shrine. See Webb Medieval Pilgrimage, 35.

${ }^{8}$ Literally thousands of similar examples could be discussed, and it is not within the scope of the present essay to delve into the types of religious pilgrimage souvenirs. For a scholarly book that treats medieval religious tokens, see Brian Spencer, Pilgrim Souvenirs and Secular Badges (London: The Stationary Office, 1998).

${ }^{9}$ Carol Rawcliffe. "Curing Bodies and Healing Souls: Pilgrimage and the Sick in Medieval East Anglia," in Pilgrimage, eds. Colin Morris, and Peter Roberts (Cambridge: Cambridge University Press, 2002), 108-140.

${ }^{10}$ Rawcliffe, "Curing Bodies and Healing Souls," 138.
} 
Brian Spencer remarked that "the sale of devotional bric-á-brac could, despite its cheapness, be a source of substantial revenue ... souvenir stalls ... were often sited just outside the entrance to a church or in the cloisters."11 Jos Koldeweij added that "places of pilgrimage were bursting with commercial activity.... In many towns the church had an interest in, and sometimes even a monopoly on, the production and sale of a varied assortment of devotionalia." 12

Significantly, the majority of pilgrims' souvenirs were made of an alloy of lead and tin, inexpensive metals that made the amulets affordable to most. ${ }^{13}$ Historian Vibeke Olsen, who studies medieval mass production, claimed that "by reducing the labor involved in their production and by using inexpensive metals or lead, these souvenirs could be sold cheaply, thereby expanding the market beyond the usual aristocratic (wealthy) patron of the arts. Virtually anyone who went on pilgrimage was able to own a standardized, inexpensive and transportable visual memento of their journey." 14 For example, in France on average, the badges were three sous (a penny) a dozen. ${ }^{15}$ In order to provide a quantifiable estimate of pilgrims' souvenirs' popularity during the medieval period, Spencer observed that based upon the quantities that have been recovered, "there

\footnotetext{
11 Spencer, Pilgrim Souvenirs, 15.

${ }^{12}$ Koldeweij, "Shameless and Naked Images," 497. See also Spencer, Pilgrim Souvenirs, 15; and Webb, Medieval Pilgrimage, 35. Webb suggested that "it was common for the clergy who controlled a shrine also to control the pilgrim-badge trade."

${ }^{13}$ The majority of the badges were made of an alloy of three parts tin to two parts lead, while the ampullae were mainly tin. See Spencer, Pilgrim Souvenirs, 35.

${ }^{14}$ Vibeke Olsen, "The Significance of Sameness: An Overview of Standardization and Imitation in Medieval Art," Visual Resources XX (March 2004): 170.

${ }^{15}$ Spencer, Pilgrim Souvenirs, 15.
} 
can be little doubt ... that across the whole of Christendom and over a period of four centuries the manufacture of these fragile objects ran into [the] many millions." 16

Within those 'many millions' lies the corpus of the sometimes sexually graphic, and always apotropaic, amulets that have been alluded to throughout the body of the present essay. The examination of the badges will begin on a broad level, addressing the corpus of English and Continental examples of apotropaia as a whole, as they share certain undeniable functional elements. Many of the similarities, however, end at this point. As the badges from England, France, and the Netherlands vary greatly with respect to their iconographical design, examples from each country will be analyzed separately. Furthermore, to aid the discussion, as there are literally hundreds of secular badges that fall under the functional umbrella of apotropaic devices, similar types will be grouped as classes, or types of objects. Due to the necessary restraints of the present exercise, not every known example will be included in the images that follow, though at least one of every class or type will be shown.

As it was noted earlier, while the historical record contains written documents concerning the production of religious pilgrimage souvenirs, there is not a single reference to the production and sale of the bawdy badges to have survived; if indeed there ever were any. What little evidence there is, is of a somewhat frustrating nature to the historian, and in order to utilize it, one must in some sense read between the lines. Jéan Gerson provides one of the better examples of the problematic and scant nature of the written primary source material. Jéan Gerson (1363-1429), the Chancellor of the University of Paris, whose vociferous critiques on the proto-capitalist stance the Church

\footnotetext{
${ }^{16}$ Ibid., 13.
} 
was taking centered on what he saw as the morally questionable objects for sale at many churches. Jos Koldeweij cited a passage from Gerson's Opera Omnia, in which Gerson denounced the "shameless and naked images for sale in churches and during church festivals."17 One may infer that "shameless and naked images" refer to the sexually explicit badges, though with the caveat that it is not certain, as Gerson did not clarify this statement, or ever specifically mention the badges.

There is a general consensus that pilgrims' badges, of both a religious and bawdy nature, were typically produced in the cities where they were sold. This made the manufacture of the badges cheaper, and as every pilgrimage destination had saints particular to the site, there were literally thousands of iconographical types found across England and the Continent. It, therefore, simply does not make sense that the badges would have been produced in larger manufacturing centers and shipped out to pilgrimage sites. Historian Diana Webb noted, "in an urban environment it would have been natural for them to be made by artisans who were in the business of producing other metal knickknacks and items of ironmongery, like the badges of entirely secular, and sometimes even pornographic character." ${ }^{.18}$ While the previous statement provides a plausible answer as to who most likely produced the evocative amulets, Webb frustratingly added, "the badge-makers of Mont St. Michel in Normandy who in 1396 pleaded poverty to King Charles VI of France were probably workers of this kind. Their overheads, they claimed, were so high and their returns so low that they were quite eaten

\footnotetext{
${ }^{17}$ Johannes (Jéan) Gerson, Opera Omnia (Antwerpen, 1706), III cols. 291-92, quoted in Jos Koldeweij, "Shameless and Naked Images: Obscene Badges as Parodies of Popular Devotion," 498-99. Koldeweij obviously titled his essay after Gerson's denouncement. ${ }^{18}$ Webb, Medieval Pilgrimage, 35-36.
} 
up by tax." of the bawdy badges in modern scholarship, and Webb unfortunately did not provide the source. If she had done so, it might open up possible lines of study, as well as reinforce the current opinion that artisans of religious pilgrims' tokens were also the makers of the apotropaic badges in question.

On the broadest level, the amulets, tokens, and badges from both England and the Continent produced between 1350 and $1500 \mathrm{CE}$ functioned as quasi-magical, apotropaic, protective devices. All of the tokens were made of a lead and tin alloy, making them affordable in nature. Another similarity is that all of the amulets were designed either to be worn around the neck, sewn on, or pinned to the outer garments. While the iconography, or subject matter of the tokens differed from location to location, and communities appeared to have certain types that they preferred, arguably each of the objects in their own way was designed to deflect the ever-malignant threat of the evil eye and its deadly possibilities. The similarities, however, end at this point. For a period lasting a little more than 150 years, the consumers of the tokens and various objects in England, France, and the Netherlands held different tastes and opinions as to what were the most efficacious iconographical forms. Apotropaic amulets and devices from England will be discussed first, as they differ the most from the Continental examples.

\section{Examples from England}

The apotropaic objects produced from 1350-1500 CE in England, in the most general sense, are of a more utilitarian and visually staid character. They do, however, as it will be discussed, make great use of visual puns on words often of a sexual nature.

\footnotetext{
${ }^{19}$ Ibid., 36.
} 
Noisemakers such as whistles, bells, and rattles, as well as miniature purse pendants were the preferred forms, although a few examples of sexually explicit badges from the country do exist. Each of the types mentioned above will be examined in turn, and by doing so, the related protective function of the varying classes will become apparent.

In England during the late medieval era, the most popular pilgrimage destination was to the shrine of Thomas Becket in Canterbury Cathedral. Thousands of religious and secular souvenirs relating to this pilgrimage site survive. Pertinent to this discussion is a grouping of three pewter Canterbury Bells (Figure 15). The bells were excavated from water sites along the River Thames, and to date, over seventy have been found. Each of the three examples shown has a trefoil suspension loop so that the bell could be worn around the pilgrim's neck. Around the base of the bell on the left is the inscription "CAMPANA THOME" (Thomas' Bell). The second bell has a similar inscription running along the top register stating "SANCTI THOMCES" (Saint Thomas), while the last bell bears no inscription. Each of the three bells was deposited in the Thames during the second half of the fourteenth century, and Spencer suggests that they date more precisely to c. $1350-1380 \mathrm{CE}^{20}$

Spencer suggested that these inscriptions "like comparable inscriptions on actual medieval church bells, was doubtless thought to be apotropaic."21 The bells' ability to make noise, however, imparted the greatest protective qualities, by "the inherent power of noise to deter evil.,"22 Common to the medieval period was the belief that when it was

\footnotetext{
${ }^{20}$ Spencer, Pilgrim Souvenirs, 125.

21 Ibid.

${ }^{22}$ Ibid., 18. He added, "hence, also the noise-making equipment, such as the horns, bells, whistles and rattles peddled at many shrines." Noise, as it is discussed in Chapter 5, was also a powerful apotropaic weapon against the evil eye for the Romans as well.
} 
rung, the apotropaic properties of the pilgrim's bell would be transferred to all within earshot. ${ }^{23}$ William Thorpe, a Lollard preacher under accusation of heresy, complained to Thomas Arundel, Archbishop of Canterbury in 1407, that parties of pilgrims had become such a nuisance, "with the noise of their singing ... and with the jangling of their Canterbury bells, they make more noise than if the King came there away, with all his clarions and other minstrels." ${ }^{24}$ This passage paints quite an aurally vivid picture of the medieval English pilgrim, and is one that can be enhanced by the introduction of another class of apotropaic noisemakers - the pilgrims' whistle.

Numerous examples of pewter pilgrims' whistles have survived from this period, with three having special significance to this discussion (Figure 16). As with the Canterbury Bells, these objects were excavated from the banks of the Thames, and were intended to be worn suspended around the pilgrims' neck. All three hollow cast examples are roosters, or cocks, an iconographical type that was common throughout the period. Spencer suggested that "as a noisy Christian symbol, the cockerel was particularly appropriate for use as an apotropaic pilgrims' whistle., ${ }^{, 5}$ Unfortunately, Spencer did not elaborate on this observation, but the medieval love of polyvalent images and affinity for wordplay leads one to wonder if the iconography of these particular whistles is a pun on the word "cock." According to the Oxford English Dictionary, by 1481, a "cock" was "a spout or short pipe serving as a channel for passing liquids

\footnotetext{
${ }^{23}$ Spencer, Pilgrim Souvenirs, 18.

${ }^{24}$ William Thorpe, quoted in Spencer, Pilgrim Souvenirs, 123. See also Thomas, Religion and the Decline of Magic, 51-52. Thomas discussed the $14^{\text {th }}$ century Lollards, who argued against the use of bells to protect against storms. He added that Lollards held similar objects as "sheer necromancy ... a hopeless attempt to endow objects with a power and strength exceeding their natural qualities." Given this observation, Thorpe's complaint against the 'jangling of their Canterbury bells' is placed in better context. ${ }^{25}$ Spencer, Pilgrim Souvenirs, 207.
} 
through." ${ }^{26}$ Based upon this late medieval definition, a "cock" can be tenably construed as serving much the same function as a penis. ${ }^{27}$ If this is so, it suggests a rather humorous play on both the meaning of the word and the iconography employed. Additionally, as there are very few known English examples of pilgrimage souvenirs with sexually explicit themes, one may suppose these whistles to be the English versions of the Dutch examples to be discussed below.

Last among the apotropaic noisemakers to be analyzed are two examples of pewter rattles (Figures 17-18) excavated from the Thames. Brian Spencer dates the class of objects to the mid-to-late-fourteenth century and noted that this form "appear[s] to be exclusively English. ${ }^{28}$ There are thirty extant examples, and commonly, the fret-worked spheres housed cockleshells - an important symbol of pilgrimage itself - pebbles, or a little bell to provide the rattling noise. The openwork pewter sphere is nearly intact in Figure 17, and the handle is preserved as well, a rarity for this class of objects. Opposite the handle is a small circular depression, originally intended to house a small mirror. Figure 18 shows a similar rattle, though the handle is missing. It is believed that this rattle would have also originally housed a small mirror at the apex of the fret-worked sphere. The function of the mirrors - other examples also contained reflective glass -

${ }^{26}$ Oxford English Dictionary, $2^{\text {nd }}$ ed. Vol. III, s. v. "cock." By the year 1618, the word was used directly in reference to the male genitalia.

${ }^{27}$ Spencer argued that "by the $14^{\text {th }}$ century the cock was everywhere recognised as a symbol for lust and adultery. ... the young men of London wore cockerel badges to advertise their virility and, perhaps, their availability." Spencer, Pilgrim Souvenirs, 318. While the present essay argues for a entirely different function of the cock whistles, Spencer's statement lends weight to the supposition of the layers of visual and verbal meaning to the iconography of the whistles.

${ }^{28}$ Spencer, Pilgrim Souvenirs, 209. 
was to deflect a malevolent glance from the evil eye. ${ }^{29}$ The bivalve cockleshell that it once enclosed is missing, but in the reconstruction drawing of a similar rattle (Figure 19), the artist portrayed the original appearance. Scholars have reached a general consensus that these rattles belong with "noise-making souvenirs and amulets, such as whistles ... and bells, each kind doubtless being deemed to possess a particular brand of apotropaic sound-magic." ${ }^{30}$ The examples of apotropaic noisemakers analyzed above, however, were not the only types of English late medieval apotropaia to have been produced between 1350-1500 CE.

Pendant purse tokens were another popular iconographical type. Seen in Figure 20 is a pendant in the form of a drawstring purse containing a coin. Rare among this type, when it was excavated from the Thames, the pendant purse still housed the imitation coin within. In this example, the coin is not sexually explicit in nature and bears on the obverse a style of royal arms employed between 1340 and $1406 \mathrm{CE}$, and on the reverse, a cross. ${ }^{31}$ The pendant purse is pierced with a lattice pattern of quatrefoils, allowing the coin to be visible within, and was intended to be worn suspended from the neck. A second, more elaborate example (Figure 21) has had the cloth bag reconstructed by modern conservators. This pendant purse is believed to date to the mid-fifteenth century, and when found, no longer contained its coin. ${ }^{32}$ Brian Spencer mentioned, but unfortunately did not illustrate, one additional pewter purse pendant excavated in London. He observed that "the lid of the purse is left open to expose a disembodied

\footnotetext{
${ }^{29}$ Ibid., 17-18.

${ }^{30}$ Ibid., 209.

${ }^{31}$ Ibid., 313.

${ }^{32}$ Ibid., 317 . He noted that "the cluster of towers above the bar mimics a decorative feature of fashionable, mid-fifteenth century purse frames."
} 
phallus, lurking in what might be deemed an appropriate habitat, since 'purse' was a common medieval metaphor for vagina as well as scrotum."33 Of the more than one thousand religious and secular badges illustrated in Spencer's book, this is one of the few to be omitted from the visual record.

Indeed, Spencer chose to not illustrate any of the "Satirical badges" discussed in his book, though he wrote quite extensively about them. He noted that "among the medieval finds from London sites are a few badges that registered disapproval of the established order by parodying reality and by poking fun at hypocrisy and human behavior generally, especially in the upper strata of society. ${ }^{34}$ The subject matter of the majority of these badges, all which date to $1350-1400 \mathrm{CE}$, is satires of the medical profession. While not apotropaic in function, they do give evidence of an important social mentality that was prevalent during the worst period of the Great Mortality - a general distrust of physicians. ${ }^{35}$ Greater study of this class of objects could provide substantive support to the present theory that the ribald badges were also in direct dialogue with the Black Death, albeit along a variant functional line. Spencer remarked that "from the middle of the $14^{\text {th }}$ century the borders of illuminated manuscripts are often inhabited by apes imitating the roles of doctors and leeches. ${ }^{36}$ These "burlesque images," to use Spencer's term, filtered down into popular culture, and were depicted in a

\footnotetext{
${ }^{33}$ Spencer, Pilgrim Souvenirs, 317.

${ }^{34}$ Ibid., 311.

${ }^{35}$ Ibid., 312. Spencer noted that "the medical profession was one of the commonest targets of medieval satire and complaint." Unfortunately, he did not mention why this was so, between 1350-1400 CE, but one can certainly argue that the satires refer to the general medieval opinion that the profession was utterly impotent in the face of the Black Death, as well as the fact that doctors had a reputation for charging exorbitant fees.

${ }^{36}$ Spencer, Pilgrim Souvenirs, 312. See also Michael Camille, Image on the Edge: The Margins of Medieval Art (Cambridge: Harvard University Press, 1992).
} 
series of leaden badges. One depicts an ape-physician "peering diagnostically at the contents of a urinal. ${ }^{37}$ Another badge shows an ape standing atop a fish and urinating into a pestle, while yet another depicts an ape-physician pounding the mortar with a longhandled pestle that Spencer infers is phallic in nature. ${ }^{38}$

As it was mentioned at the beginning of this section, the badges excavated in England tend towards an understated, staid character. Spencer somewhat prudishly observed that "Londoners appear to have preferred to reveal their attitudes to sex through subtler, less offensive motifs. ${ }^{, 39}$ Arguably, Spencer is missing the bigger picture, and reverts to an archaic view of this class of tokens, and erroneously assumes that because the badges display genital organs, they must of necessity speak of medieval sexuality and the modern notions surrounding it. There is no doubt, however, the English badges are of a more conservative nature, and compared with those from France and the Netherlands, there are very few bawdy or ribald examples. There are, however, other than the phallic pendant purse discussed above, two English examples dating between 1350-1450 CE of belled and winged phallus badges, a type, as it will be seen, that is extremely common in France and the Netherlands. These three examples "appear to be the only explicitly sexual medieval badges to have been found at London., ${ }^{, 40}$

\footnotetext{
${ }^{37}$ Spencer, Pilgrim Souvenirs, 312. He noted that urinals were "the universal emblem of the medieval physician." Humoralism, the predominant medical theory of the period discussed above, placed much emphasis on the 'reading' of urine, as it was one was to diagnose an imbalance of the humors. Spencer added, "there can be little doubt that these badges were a satirical jibe at the questionable concoctions devised by the medieval medical profession."

${ }^{38}$ Spencer, Pilgrim Souvenirs, 312.

${ }^{39}$ Ibid., 318.

${ }^{40}$ Ibid., 317.
} 
Spencer noted that of the French and Dutch examples, some "appear to be intentionally comic and gratuitously vulgar, others fiercely satirical, but the majority, indulging in various forms of sexual exhibitionism are thought to have served an apotropaic purpose, in the time-honoured belief that indecent images distracted the eyes of ill-disposed spirits. ${ }^{, 41}$ He regretfully did not attempt to tie in the English examples with the previous statement, though there should be no doubt that the winged phalli badges from London served exactly the same apotropaic purpose. It is extremely unfortunate that Spencer chose not to illustrate the satirical badges, the belled and winged phalluses, as well as the phallic purse pendant, because they are truly important artifacts, and his curious omission only adds to the enigma surrounding these objects. ${ }^{42}$ Further study of these unique items could greatly add to the current base of scholarship concerning this class of objects, and might provide a significant iconographical link between the examples from England, France, and the Netherlands. The discussion will next turn to a brief analysis of a select few French examples of apotropaic tokens dating from the period between 1350-1500 CE.

\section{Examples from France}

In 1848, the government of France began the enormous project of dredging the Seine to alleviate the problems associated with the vast amounts of river silt that had accumulated over the years, causing dangerous currents and weakening the quays and bridges. Through personal contacts, amateur archaeologist Arthur Forgeais was allowed to sift through the silt and debris daily to excavate artifacts. By the mid $1850 \mathrm{~s}$, he had

\footnotetext{
${ }^{41}$ Ibid., 317-318.

${ }^{42}$ Historian Nicola McDonald arrived at much the same conclusion. See McDonald, Medieval Obscenities, 8. She noted that Spencer "completely obliterates all genital or sexual material from the visual record."
} 
amassed a remarkable collection of thousands of items dating from the Neolithic to the then modern times. The majority of the finds, however, were medieval pilgrims' badges. Forgeais' collection was so significant, in fact, that in 1861, Emperor Napoleon III purchased 3,300 of the objects for an estimated eighteen thousand Francs, and had them placed on permanent display in the Cluny Museum. ${ }^{43}$

Throughout the $1850 \mathrm{~s}$ and $60 \mathrm{~s}$, Forgeais systematically catalogued and published accounts of the majority of the artifacts. Intrigued as Arthur Forgeais was by the numerous leaden badges, he was unsure what to make of a specific type of tokens he had discovered. ${ }^{44}$ In 1865 he published a sixteen-page booklet entitled Priapées, which illustrated twenty-five sexually explicit amulets excavated from the Seine, including a reconstruction drawing of the ten tokens seen in Figure $3 .^{45}$ Five of the tokens have on their obverse an image of a phallus, and in all but one example, they are winged, with one also having a bell suspended from the glans. The other five tokens have images of the female pudendum on their obverse. On the reverse of all ten examples, there are varying representations of a cross. The addition of the cross suggests that to their medieval owners, the addition of Christian symbols would strengthen the token's traditional apotropaic function. People were in effect, 'hedging their bets' by the admixture of Christian and pre-Christian iconography utilized on the tokens.

Significantly, the tokens do not have a looped bail, or any other method to suspend them from a cord worn around the neck. Originally the tokens might have been

${ }^{43}$ Bruna, "Medieval Sexual Badges," 3-4. The Carnevalet Museum, the Museé des Beaux-Arts, the Museé des Chartres, the Museum of Antiquities in Rouen, and private collectors purchased the remainder of Forgeais' objects.

${ }^{44}$ Bruna, "Medieval Sexual Badges," 5. See also Van Beuningen and Koldeweij, HP1, 2. See also Van Beuningen, Koldeweij, and Kicken, $H P 2$.

${ }^{45}$ Bruna, "Medieval Sexual Badges," 5. 
intended to be carried in pockets, much like a lucky coin is today. There is, however, one other possibility that necessitates a return to the work of Brian Spencer, and the pendant purses excavated from the Thames. With regards to the English examples of purse pendants (Figures 20-21), Spencer offered that "the presence of the imitation coins ... suggests that the pewter purse pendants were seen as lucky charms destined to attract money to their owners by sympathetic magic." ${ }^{, 46} \mathrm{He}$ added that the "expectation of sympathetic magic, like attracting like, was presumably also associated with the wearing of coins. ${ }^{, 47}$ This is a very interesting supposition, for, if it is correct, it bridges the functional gap between the English purse examples and Forgeais' sexually explicit tokens.

The theory that the English coins functioned as devices of sympathetic magic, intended to bring their wearer money, translates into another possibility with the French examples. It is very plausible that the coins depicting winged phalli and pudenda were indeed intended to attract the evil eye, through sympathetic magic, and that the tokens provide yet another example of "priapic figures as amulets, to be carried on the person as preservative against the evil eye and other noxious influences. ${ }^{, 48}$ Furthermore, it is plausible that the phallic and pudenda imitation coins were designed with the intention to be housed within French examples of purse pendants. It is likely that Arthur Forgeais found similar purse examples, but as the tokens had become separated, he did not associate the two classes of objects as being related. It is, however, impossible to state

\footnotetext{
${ }^{46}$ Spencer, Pilgrim Souvenirs, 315.

${ }^{47}$ Ibid., 317.

${ }^{48}$ Wright, The History of Phallic Worship, 59. See also Stone, The Story of Phallicism, 92. Both scholars describe the appearance of the amulets and give similar accounts of Forgeais' excavations.
} 
this with certainty, as the catalogues of Forgeais' finds could not be located for the present discussion.

The examination of ribald French apotropaic amulets has focused on a small selection of ten tokens excavated from the Seine by Arthur Forgeais. While there are a few other badges of an explicit nature that have been found in France, the phallic and pudendum coins shown in Figure 3 have received the greatest amount of scholarly treatment. Furthermore, for the purposes of the present discussion, the French examples have been included to serve as an iconographical bridge between the English apotropaic objects and those from the Netherlands. It will become obvious in the examination to follow, that the Dutch badges differ considerably in subject matter from the English examples, though they were intended to serve an entirely similar function. Moreover, the Dutch examples constitute the largest portion of this type of objects by far, as well as undeniably showcasing the greatest and most unique variations in iconography. Indeed, for reasons that are still unclear, late medieval consumers of the bawdy amulets from the area of the Netherlands and the Low Countries preferred their amulets to be as visually titillating, shocking, and as uninhibited as possible, and the artisans strove courageously to meet their demands.

\section{Examples from the Netherlands and Low Countries}

To date, one hundred and thirty one secular badges of a bawdy and ribald nature dating between c. 1350-1500 CE have been found in the Netherlands. To speak in depth about each of the examples would be an exercise well beyond the scope of the present essay. Therefore, the extant badges will be grouped into categories of similar examples, with at least one from each type or group illustrated. In general, the badges from the 
Netherlands and Low Countries can be grouped into eight broad categories or types:

ambulant and/or winged genital creatures, couples having sex, animals, humans

interacting with genital creatures, architecturally influenced images, pudenda and phalli

in nature scenes. The last two categories, miscellaneous pudenda and miscellaneous

phalli, were created because many of the badges do not easily fit within a category, and to

date, provide unique examples of their iconographical type. ${ }^{49}$ A chart showing the

location and number of excavated badges follows (Table 1). ${ }^{50}$

Table 1: Location where badges were found and number of existing examples.

\begin{tabular}{|l|c|}
\hline City/Location Where Badges were Found & $\begin{array}{c}\text { Number of } \\
\text { Examples }\end{array}$ \\
\hline Amsterdam, Netherlands & 11 \\
\hline Bruges, Belgium & 8 \\
\hline Dordrecht, Netherlands & 10 \\
\hline Enkhuizen, Netherlands & 1 \\
\hline Groningen, Netherlands & 1 \\
\hline Ypres, Belgium & 13 \\
\hline Kampen, Netherlands & 1 \\
\hline Leiden, Netherlands & 2 \\
\hline Middleburg, Zeeland Province, the Netherlands & 7 \\
\hline Nieuwlande, Zeeland Province, the Netherlands & 41 \\
\hline Poortvliet, Zeeland Province, the Netherlands & 1 \\
\hline Province of Zeeland (exact location not listed) & 1 \\
\hline Reimerswaal, Netherlands (the city no longer exists) & 2 \\
\hline Rotterdam, Netherlands & 10 \\
\hline S'-Hertogenbosch, Netherlands & 6 \\
\hline Schoonaarde, Belgium & 1 \\
\hline Sluis, Zeeland Province, the Netherlands & 2 \\
\hline Tolsende & 2 \\
\hline Valkenisse, Zeeland Province, the Netherlands (city no longer exists) & 6 \\
\hline
\end{tabular}

${ }^{49}$ The eight categories were created solely to aid discussion.

${ }^{50} H P 1$ and HP2 contain illustrations of each of the 131 examples, as well as their dimensions, location, date, and alloy composition. The table above opens up one possible line of study that is beyond the scope of the present essay. It would be interesting to quantify plague mortality rates for the cities listed above, and to see if in any way, the levels of mortality relates in a meaningful way to the number of excavated badges. For example, one wonders if perhaps Zeeland Province, where the majority of badges were found, was one of the most devastated regions. 


\begin{tabular}{|l|c|}
\hline Vlaanderen (Flanders) & 1 \\
\hline Vlaardingen, Netherlands & 1 \\
\hline Westenschouwen, Zeeland Province, the Netherlands & 3 \\
\hline Total: & 131 \\
\hline
\end{tabular}

Ambulant and/or winged genital creatures constitutes the largest portion of the extant corpus of leaden badges, with at least 49 known examples. Within this group are badges depicting pudendum pilgrims, ambulant and winged pudenda and phalli, phalli and pudenda riding on donkeys or horseback, and pudenda roasting penises over vulva grease traps. Eleven examples of pudendum pilgrims found in the Netherlands exist (Figures 22-25 show four of the pilgrims). In each instance, the humanized pudendum is dressed as the archetypal medieval pilgrim. She invariably wears her pilgrims' hat and boots, has her scrip (knapsack) strapped to her back, and also carries her staff and rosary. Variations of the type include the pudendum pilgrim standing on a strip of ground (Figure 23), a pudendum pilgrim accompanied by her male counterpart (Figure 24), while some wear their own phallic pilgrimage badges pinned to their labia, others walk on patens, and on one badge, the pudendum pilgrims' staff is crowned by a phallus. ${ }^{51}$

Numerous other examples of ambulant pudenda survive. One example discovered in Flanders shows the pudendum wearing phallic badges, while a phallus bows in courtly fashion (Figure 26). The phallus seems to nearly penetrate his companion, who along the top portion of her labia wears four prominently displayed phallic badges. The inscription beneath the ambulant couple reads "PINTELIN," and to

${ }^{51}$ Koldeweij, "Shameless and Naked Images," 508. No images of these badges could be located for the present discussion. 
date, no scholar has been successful in accounting for its meaning. ${ }^{52}$ Other examples of the category include pudenda crowned with phalli, walking on stilts (Figures 27-29), a phallus riding what is either considered to be a horse or a donkey (Figure 30), and badges that have been colloquially called, "Pussy Goes A' Hunting," (Figures 1 and 31). In the two known examples of this type, the pudendum is mounted on either a horse or a donkey, wears a phallus crown, and is armed with a whip and crossbow. Yet another badge portrays a pudendum turning a penis on a roasting spit over a vulva grease trap (Figure 2).

Ambulant and winged phalli constitute the largest portion of the category. Perhaps one of the finest and better-known badges of this type depicts three ambulant phalli carrying a crowned vulva on a processional bier (Figure 6). The penises' scrota are fashioned seemingly into pantalettes, showing their muscular calves; their arms terminate in phallic hands, and each also has a phallic tail. The mandorla-like pudendum wears a jeweled crown. At least one dozen other badges portray ambulant and winged phalli (Figures 32-38 for seven examples). In some of the badges, a bell hangs from the glandes (Figures 32-34), others wear crowns (Figures 33-34), a bird perches on one phallus creature (Figure 35), while two other ambulant phalli stand on vulvas (Figures 36-37). Historian Anthony Colantuono suggested that the ambulant phallus badges were "modeled on a common type of ancient Roman fertility votive and were probably believed to provide amuletic or apotropaic protection, bringing good fortune or averting

\footnotetext{
${ }^{52}$ Koldeweij, "Shameless and Naked Images," 509. One suggestion is that the middleDutch word translates to 'penetration.'
} 
evil. ${ }^{53}$ Each of the examples discussed above also has a tail, which is a feature common to Roman examples to be examined in greater detail to follow in Chapter 5 .

The second category of the badges contains various examples of couples - usually human - having sex. Several of this type are iconographically located in nature, while others depict the amorous couples in more pedestrian settings. Figures 39 and 40 show couples having sex, presumably in open fields, while a man and a dog watch voyeuristically from the edge of the scene in both of the examples. Figure 41 is somewhat enigmatic, as it depicts a couple having sex on a clam shell (cf. to Figure 42 a clam shell locket that when opened displays a vagina). In what is thought to be a tavern, the couple in Figure 43 has sex while another man on the second floor pours wine.

The third category of bawdy badges is animals, and identical to similar examples from England, depict roosters, or as they are also called, cocks. ${ }^{54}$ Three typical badges of this type can be seen in Figures 44-46. Interestingly, in Figure 46, the badge illustrates the couple - in this case a cock and a hen - having sex. Images located within this group provide the nearest iconographic relation to those discussed earlier from England. Perhaps the similarities are coincidental, or perhaps artisans from the Netherlands were imitating the type from England, or vice-versa.

${ }^{53}$ Anthony Colantuolo. "The Penis Possessed: Phallic Birds, Erotic Magic, and Sins of the Body, ca. 1470-1500," in The Body in Early Modern Italy, ed. Julia L. Hairston and Walter Stephens (Baltimore: The Johns Hopkins University Press, 2010), 102. Colantuolo makes an interesting argument for parallels between examples of phallic badges and figures in Leonardo da Vinci's Codex Atlanticus, as well as other contemporary examples of metalwork. I am not convinced, however, of his ultimate interpretations concerning some of the comparanda. I am grateful to Dr. John Hunt for leading me to this source.

${ }^{54}$ Brian Spencer unfortunately chose to not illustrate any of the English examples of roosters, or cocks. The reasons for his omission have been discussed previously. 
The fourth broad category of badges can be loosely defined as humans interacting with ambulant phallus creatures. Numerous examples of this type exist, though for the purposes of the present essay, only a few of the more illustrative badges will be discussed (Figures 47-50). Figure 47 shows an ambulant and winged phallus, with a bell suspended from the glans (cf. Figures 32-34), while a man, thought to be a troubadour, plays a harp while riding on the creature's back. Figure 48 is similar, and depicts a man riding atop another ambulant winged and belled phallus. In perhaps one of the best examples of badges excavated in the region, Figure 49 illustrates a finely detailed ambulant phallus with a tail composed of eight smaller phalli, while a woman pushes a wheelbarrow filled with three phalli along the creature's back. Figure 50 is similar, though a man pushes a wheelbarrow along the phallus' back.

The fifth category to be analyzed is badges that seem to have been influenced from enigmatic architectural decorations known as Sheela-Na-Gigs. ${ }^{55}$ Curiously, architectural Sheela-Na-Gigs, believed to date from the eleventh and twelfth centuries $\mathrm{CE}$, are crudely carved stone depictions of emaciated hags grasping their prominently displayed pudenda, and are confined to the British Isles, with the majority found in Ireland (Figures 51-52). Sheela historian Barbara Freitag noted that much like the paucity of scholarship surrounding the bawdy badges, archaeologists "tended either to

\footnotetext{
${ }^{55}$ See Barbara Freitag, Sheela-Na-Gigs: Unraveling an Enigma (London: Routledge, 2004); Joanne McMahon and Jack Roberts, The Sheela-Na-Gigs of Ireland and Britain: The Divine Hag of the Christian Celts - an Illustrated Guide (Dublin: Mercier Press, 2000); Jørgen Andersen, The Witch on the Wall: Medieval Erotic Sculpture in the British Isles (Copenhagen: Rosenkilde and Bagger, 1977); Ronald Sheridan and Anne Ross, Gargoyles and Grotesques: Paganism in the Medieval Church (Boston: New York Graphic Society, 1975) and Michael Camille, Image on the Edge: The Margins of Medieval Art (Cambridge: Harvard University Press, 1992) for wonderful studies of architectural and manuscript obscenities.
} 
ignore [Sheelas] altogether or to label them as lewd, barbarous or repulsive." ${ }^{.56}$ It has only been within the last several decades that the Sheelas have received any serious academic attention.

Originally located above the entrances to Irish and English Catholic churches (most were removed or destroyed during the sixteenth century period of iconoclasm), Sheelas were, as Freitag argued, "incorporated in a Christian context, but divorced from her roots in pre-Christian tradition ... [and need] to be seen as some powerful manifestation of continuity with the past. ${ }^{, 57}$ Scholars generally agree that Sheelas were apotropaic protectors, and belong "to the realm of folk deities and as such [are] associated with life-giving powers, birth and death and the renewal of life." Furthermore, historians believe that Sheelas were more specifically concerned with protecting expectant mothers, and women during childbirth. ${ }^{59}$

Dutch artisans of the bawdy badges, in a method of iconographic transmission not yet understood, produced Sheela-Na-Gig badges between c. $1350-1500 .{ }^{60}$ Figure 53 shows a badge with the nearest visual relation to the architectural antecedents from the British Isles. This badge Sheela is emaciated, has deflated breasts, a prominent naval, and a swollen, and protruding pudendum. Figure 54 provides another example of a Sheela badge, and interestingly, the Dutch artisan chose to have her hold a disembodied phallus in her right hand. Keeping with the original nature, though not the gender of

\footnotetext{
${ }^{56}$ Freitag, Sheela-Na-Gigs, 1. See also McMahon and Roberts, Sheela-Na-Gigs, 11-19.

${ }^{57}$ Freitag, Sheela-Na-Gigs, 1.

${ }^{58}$ Ibid., 1-2.

${ }^{59}$ Barbara Freitag, and McMahon and Roberts discuss this throughout their books.

${ }^{60}$ McDonald, Medieval Obscenities, 7. See also Easton, "Was it Good for Your Too?," 15-16.
} 
Sheela images, Figure 55 illustrates a male Sheela prominently displaying his priapic member.

The sixth category of badges is phalli and pudenda in scenes of nature, and more specifically, contain images of plant life. Figure 56 illustrates a badge that is a winged phallus (one wing is missing) plant with pudenda leaves. The badge in Figure 57 reverses the iconography, as a winged pudendum surmounts the plant, and phalli constitute the leaves of the plant. Figure 58 shows ambulant and belled phalli tending a penis tree. Significantly, badges of this type evince relationships with both the Classical world (cf. to Figures 72-74), and as one scholar suggests, with text from the Malleus Maleficarum, written in $1486 .{ }^{61}$ P.G. Maxwell-Stuart, in the newest translation of the Malleus Maleficarum (The Witches' Hammer) discussed the phallus badges that were so popular to the contemporary handbook for hunting witches. ${ }^{62}$ He noted that "Institoris's well-known anecdote about witches' keeping penises in a bird's nest should perhaps be understood in this magico-artistic context. ${ }^{, 63}$ While a great deal of research needs to be

${ }^{61}$ Heinrich Institoris and Jakob Sprenger, The Malleus Maleficarum, trans. and ed. P.G. Maxwell-Stuart (Manchester: Manchester University Press, 2007).

${ }^{62}$ Maxwell-Stuart, The Malleus Maleficarum, 187.

${ }^{63}$ Ibid., 233. The anecdote referred to above states, "so what are we to think about those witches who shut up penises in what are sometimes prolific numbers, twenty or thirty at a single time, in a bird's nest or some kind of box, where they move about in order to eat oats and fodder, as though they were alive..." (pages 152-153). The authors of the Malleus Maleficarum strove to convey that the witches did not actually remove men's penises. It was only through prae stigium - acts of illusion - that men were convinced that their penises had been stolen. Institoris and Sprenger also included instructions for men whose members had been taken through magic, to regain their penises. See Maxwell-Stuart, The Malleus Maleficarum, 84-153, and 187. For a scholarly examination of the Witches' Hammer, among other related topics, see Brian Patrick McGuire, Jean Gerson and the Last Medieval Reformation (University Park, PA.: Pennsylvania State University Press, 2005). 
undertaken before conclusively relating images of this type to text found in the Malleus Maleficarum, there are undeniably, intriguing parallels.

The remaining two categories of bawdy amulets are miscellaneous pudenda and phalli. The types of iconography employed on these examples do not fit within the other groups so far discussed, and to date, many of these badges provide the only known specimen. Figure 59 illustrates a pudendum climbing a ladder, while Figure 60 shows a phallus pendant, clearly designed to be worn suspended from a cord around the neck. Figure 61 is a unique image of two women forging a phallus with what appears to be hammers and chisels. Ambulant and winged phalli manning sailing vessels could perhaps constitute another class, though as there are only three known examples, it seems iconography of this type is rather unique (Figures 9, and 62-63).

So far a broad range of amulets has been examined, and yet several fundamental questions about them remain. Nicola McDonald lamented that the amulets discussed throughout this chapter "cannot simply have been used to ward off evil; [they] seem to purposefully ludic, yet we do not know the gender, age, or social identity of [their] wearers, whether [they were] festally specific or quotidian, whether [they] served to titillate or shock, excite or repulse. ${ }^{, 64}$

The present discussion can answer some of McDonald's observations. Most likely, given the cheapness of the metals used, and the quantities produced, the ludic badges were intended for sale to the common man and woman who went on pilgrimage to sites throughout Europe. ${ }^{65}$ Moreover, given that the iconography of the badges

\footnotetext{
${ }^{64}$ McDonald, Medieval Obscenities, 11.

${ }^{65}$ Koldeweij came to much the same conclusion. He noted, "in view of the frequency with which they turn up among late-medieval finds, they were surely worn by many
} 
illustrate both male and female genitalia as well as characters, it is likely that the badges were produced for both genders. Furthermore, it can be argued that for the period between 1350-1500, contemporaneous to their production and consumption, the badges were indeed quotidian and common objects, at least in the areas where examples have been excavated.

To answer the last of McDonald's questions, it seems highly plausible to conclude that the badges did in fact serve to 'titillate or shock, excite or repulse.' For those were the very means by which they would protect their owners from the evil eye, and the Black Death, which could be transmitted through its gaze. Most importantly, the badges functioned to ward off the evil eye through the ability to excite laughter, in the very same manner as employed by the Roman apotropaic objects examined below. Laughter was indeed, the intended point, for laughter in and of itself, had the power to dispel the evil eye. ${ }^{66}$ Indeed, it is hard for one to not laugh when presented with some of the imagery employed on the tokens, such as, a pudendum dressed and ready to go on pilgrimage. Images of this and other types are truly humorous, and one assumes that the same was true for their late medieval owners as well.

Several historians have treated the subject of laughter, and a very brief examination of some of their remarks follows. Marina Warner commented that "there is no other response to these images and punning devices than laughter. Laughter is interesting in its complexity of response: a release from embarrassment, a recognition of rudeness and outrageousness, as well as a kind of shock that the unspeakable has been

people and in view of the cheapness of these popular mass-produced souvenirs, they were certainly not intended for the upper classes." Koldeweij, "Shameless and Naked Images," 504-505.

${ }^{66}$ Clarke, Roman Sex, 108. 
spoken, the obscene brought in from the wings to take centre stage. ${ }^{, 67}$ Moreover, as historian Michael George suggested, "to deny the existence and strong influence of humor and laughter in the Middle Ages is to deny medieval people an aspect of humanity that Aristotle claimed was unique to human beings: laughter. ${ }^{, 68}$ Aron Gurevich suggested "laughter was the emotional acknowledgement of the external antagonism of good and evil, sacred and profane, which lay at the base of the medieval world-view." Gurevich added that "the grotesque reduces the great to the small, profanes the sacred, and thus can come close to sacrilege.... The grotesque can evoke merriment, but it does not destroy fear. Rather, it unites them in some contradictory feeling in which we are supposed to assume both sacred trepidation and merry laughter as an indissoluble pair. ${ }^{, 70}$ Following Gurevich's belief that the medieval grotesque profanes the sacred, it is arguable that most of the badges from England, France, the Netherlands, and the Low Countries undeniably perform that function. It is hard not to conclude that a badge depicting ambulant phalli carrying a crowned pudendum on a processional bier (Figure 6) is not profaning the sacred. Moreover, it is just as plausible to assert that examples of amulets of pudenda pilgrims (Figures $7 \& 22-25$ ), and couples having sex (Figures 39-41, 43) do the very same thing. As with regards to the remainder of the iconographic corpus, in one way or another, whether they evince examples of profaning work (Figures 2, 9, 31,

\footnotetext{
${ }^{67}$ Marina Warner, forward to The Secret Middle Ages, by Malcolm Jones. (Westport, Conn.: Praeger, 2002), xiv.

${ }^{68}$ Michael W. George. "An Austere Age Without Laughter," in Misconceptions About the Middle Ages, eds. Stephen J. Harris and Bryon L. Grigsby (New York: Routledge, 2008), 185. George focused his discussion on examples of French Fabliaux, German Schwänke, Italian Novelle, and English authors such as Chaucer.

${ }^{69}$ Gurevich, Medieval Popular Culture, 193. See also Bakhtin, Rabelais and His World, 1968.

${ }^{70}$ Ibid., 204 and 207.
} 
49-50, 61, 62-63), are visual verbal puns (Figures 16, 44-46), or image types whose meaning has unfortunately been lost during the preceding 650 years (Figures 13, 27-29, $32-38,56-60$ ), the badges undeniably display a profaning of the everyday, quotidian tasks that made up lives of the common late-medieval man and woman. The bawdy badges performed the feat of profaning the sacred through laughter, and in so doing, provided their late-medieval owners magical protection from the threat of the evil eye and the Black Death. 


\section{CHAPTER V}

\section{HISTORICAL ANTECEDENTS}

After examining the body of the late medieval evocative amulets from England, France, and the Low Countries, the answer to the question of whether or not the artisans were producing entirely new iconographical types, or merely expanding upon much older material, still remains. The answer, unfortunately, is as problematic as the badges themselves, for one can argue equally for both artistic innovation and iconographic imitation, as both are true. The discussion to follow will address both sides of the interpretive coin.

One cannot deny the originality of much of the corpus of the bawdy badges. Art Historian Lawrence Nees observed that "the original artist not only displays new and fresh ideas, but is aware of and proud of the novelty, and contributes novelties upon which other artists will eventually build a broader new direction in the general development of art.... An original artist is generally thought to be influential rather than merely idiosyncratic." For instance, images such as Figures 62 and 63, showing ambulant phalli manning sailing vessels, evince the novelty of the medieval artisans. Nees added the following caveat, however, that "medieval artists invented a host of new

\footnotetext{
${ }^{1}$ Lawrence Nees. "The Originality of Early Medieval Artists," in Literacy, Politics, and Artistic Innovation in the Early Medieval West: Papers Delivered at 'A Symposium on Early Medieval Culture' Bryn Mawr College, Bryn Mawr, PA., ed. Celia M. Chazelle (Lanham, MD.: University Press of America, 1997), 79.
} 
images ... new interpretations of images having long traditions." ${ }^{, 2}$ In other words, Nees is suggesting that even innovative art of the medieval period has at its foundations, much older traditions.

It is critical to understand that the late medieval artisans who produced the suggestively ribald artifacts were not necessarily artistic innovators in the modern sense of the term. While these anonymous craftsmen from the Netherlands, Low Countries, England, and France employed artistic themes and images uniquely prevalent in late medieval popular culture, say, for instance, mounted vulvas on horseback armed with a whip and crossbow (Figures 1 and 31), the artisans were undeniably working within a long-established iconographical tradition dating back to the Classical world. ${ }^{3}$

According to this interpretation, the late medieval artisans were in a sense copying much earlier works. They may not have been fully cognizant of this fact, and certainly added original iconographical content to the apotropaic corpus. Art historian Jennifer Lee cogently offers, however, that "since the publication of Richard Krautheimer's pioneering work of architectural copies of the Holy Sepulchre in 1942, art historians have understood that a medieval copy could be a loose or obscure reference to the original rather than a replica." ${ }^{4}$ This is crucial to understand; that the concept of a

\footnotetext{
${ }^{2}$ Nees, "The Originality of Early Medieval Artists," 94.

${ }^{3}$ For the purposes of the present discussion, only a select few Greek and Roman examples of apotroapaia will serve as comparanda. One could write an entire book on sexually suggestive apotropaic devices found in most western and eastern cultures, including those from the Greeks, Romans, Egyptians, Mycenaeans, and Celts.

${ }^{4}$ Lee, "Beyond the Locus Sanctus," 364. See also Richard Krautheimer, "Introduction to an Iconography of Medieval Architecture," Journal of the Warburg and Courtauld Institutes 5 (1942): 1-33. See also Nees, "The Originality of Early Medieval Artists," 81. Nees wrote of one other foundational work, and it is worth quoting at length. He noted, "the methodological Bible of the model-seeking approach to early medieval art is Kurt Weitzmann's Illustrations in Roll and Codex, first published in 1947. In his magisterial
} 
medieval 'copy' varies drastically from the modern notion of what constitutes a 'copy.'

To be deemed a copy in the modern era, something must be an exact replica, whereas for the medieval person, a 'copy' only had to include one or two salient features, and did not have to mirror the original. Therefore, while the artisans and the people who wore the badges tailored the images to contemporaneous popular social and cultural forms - i.e. by including images of pilgrims, troubadours, and religious processions, they employed images that at their foundation were medieval copies of Greek and Roman apotropaia. Scholars that have studied the late medieval amulets agree that there is remarkably strong evidence to lend support to this belief, and the following discussion will outline their broader arguments.

Thomas Wright, a pioneering historian of the subject, observed of the medieval examples, "these characteristics show either a very distinct tradition of the forms of the Roman phallic ornament, or an imitation of examples of Roman phalli then existing.,"5 Malcolm Jones suggested an "ultimate derivation from just such Roman models, perhaps due to the discovery of a cache of bronzes including tintinnabulae in the late medieval Netherlands. ${ }^{{ }^{6}}$ Historian Jos Koldeweij also held that a case could be made for medieval copying. He claimed, "the erotic, titillating badges should not be regarded as isolated, late medieval curiosities ... one notices a striking resemblance to the [Greco-Roman]

and still fundamental work Weitzmann lays out evidence for the importance of considering the transmission of pictorial ideas from one work of art, the model or prototype, to another, the copy, proposing an essentially philological method of recensional analysis."

${ }^{5}$ Wright, Sexual Symbolism, 63. See also Nicola McDonald, ed., Medieval Obscenities. New York: York Medieval Press, 2006. See also Colantuolo, "The Penis Possessed," 102.

${ }^{6}$ Jones, The Secret Middle Ages, 254. Unfortunately, Jones did not state when and where the bronzes were discovered in the Netherlands. Tintinnabulae are discussed below. 
iconographic tradition, although this much older material cannot be obviously related to it in terms of a continuous tradition." ${ }^{\prime 7}$ It is tempting, based on the visual similarities, to argue for the strong possibility of a continuing functional tradition between the ancient and medieval examples as well. The cultures of both the Roman and medieval eras were firmly convinced of the tangibility of malevolent spirits and forces, and both employed apotropaic images and objects meant to provide a substantive level of protection. Koldeweij's previous statement, however, prudently states that based on the absence of physical evidence, it is hard to prove a direct, continuous functional connection between the Roman prototypes and the medieval manifestations so far examined.

How does one then explain why, in two separate historical periods, separated by more than one thousand years, objects of a striking visual similarity were produced for similar purposes? Arguably, based on the lack of intervening historical evidence, one is faced with a dilemma. While the extant body of material evidence and the general scholarly consensus speaks overwhelmingly to the probability of a shared tradition, they do not speak necessarily to identical, dependant developments between the Roman and late medieval examples of apotropaia. It is therefore likely, that in some still undetermined way, medieval artisans resurrected ancient prototypes, or at the very least employed iconographic types that had never ceased to exist. In other words, while it must be stated that no phallic or vulvic European amulets, carvings, or household objects are known currently to date between the fourth and early fourteenth centuries CE, it does not necessarily mean that they never existed. These supposed objects could have been carved out of wood or wax, neither of which would have survived. One can also

\footnotetext{
${ }^{7}$ Koldeweij, "Shameless and Naked Images," 500-501.
} 
conjecture that somewhere out there, the 'missing-link' is awaiting excavation, but once again, one can only rely on what is currently known.

Recognizing that the badges' ultimate derivation in all probability lies along a line of Roman and Greek iconographical descent, the lines of functional interconnectedness must now be established in order to accurately contextualize and interpret these enigmatic late medieval objects. This will allow for a meaningful explanation of the objects that helps to clarify their cultural importance, as well as the perceived functionality assigned to the late medieval badges produced between 1350-1500 CE. Perhaps most importantly, the discussion that follows leads to a plausible, and arguably significant interpretation that, to date, scholars in the field of medieval obscenities have yet to offer. At the same time, by discussing the antecedents of the late medieval amulets, a pattern of historical continuity emerges that highlights the interconnectedness of the themes so far examined.

The analysis of late antique and classical antecedents must begin with a brief return to the discussion of the concept of the evil eye. Unlike in the modern western culture, evil was a palpable entity in late medieval culture, and it was even more so to the Romans and Greeks. Historian Jonathan Sumption remarked that "ordinary people could not regard evil as an abstract force; to them it was real, visible and tangible, capable of inflicting actual physical damage. ${ }^{.8}$ People truly believed they needed protection, and one method for achieving this was either through the wearing of magical amulets, or through the prominent display of apotropaic devices in both private homes and public spaces. The ultimate reason, as it was discussed in great detail above (see especially page

\footnotetext{
${ }^{8}$ Sumption, The Medieval Journey to God, 11. He added that a "pantheistic view of nature suggested to them that the physical world harboured malignant forces hostile to men."
} 
35), for displaying the devices so prominently was that it was widely believed that in order to avert the evil eye, one must divert its gaze to something that would, in essence, absorb the evil. Frederick Elworthy, a nineteenth-century historian of the evil eye, discussed earlier, offered that to "neutralize the maleficent look it is considered essential to attract it toward something striking, by way of diverting it from the object liable to injury." Images of the phallus were thought to be the most efficacious objects.

Numerous classical authors discuss the protective efficacy of the phallic amulets, household items, and sculptures found throughout ancient Greece and Rome designed to protect one from the evil eye and other malignant forces. Plutarch declared that the objects derived their efficacy from the fact that they acted "through their strangeness and ridiculousness of their forms, which fix the mischief-working eye upon themselves." 10 Pliny the Elder referred to the phallic amulets as satirica signa, and wrote of their prominence in Pompeii. ${ }^{1}$ Figures 64-66 attest to the frequency of this type of image in the Roman world. Figure 64 illustrates a terra-cotta plaque of an erect penis with the inscription HIC HABITAT FELICITAS ("here dwells happiness"). It was originally hung outside of a Pompeian bakery, and was intended to make the bread rise. Figure 65 shows a fresco depicting Priapus weighing his enormous membrum virile, and was originally placed in the entryway to the House of the Vettii in Pompeii to protect visitors. Figure 66 shows a fresco painting of a priapic Mercury that originally was located at the entrance to a bakery in Pompeii. Similar to the terra-cotta plaque, this image of Mercury was intended to protect the bakery's customers, and to insure that the bread would rise.

\footnotetext{
${ }^{9}$ Elworthy, The Evil Eye, ix.

${ }^{10}$ Plutarch, Symposia, v. 7, quoted in Elworthy, The Evil Eye, 143. See also, Jones, The Secret Middle Ages, 253. Jones referred to Plutarch's Quaestiones Conviviales, v. 7. 3.

${ }^{11}$ Elworthy, The Evil Eye, 154.
} 
An analysis of two late medieval amulets reveals an iconographic link with their Roman apotropaic antecedents. Prior to 1976, scholars identified the two winged phallus badges seen in Figure 67 as late antique. ${ }^{12}$ Both pewter examples are winged, have tails, and though the top phallus is missing its ambulant legs formed from its scrotum, they would have been nearly identical with those of the figure below. There are, however, several notable differences between the two examples. The phallus on the top has a bell suspended from the glans. The phallus shown on the bottom has its own penis. So far in this discussion, late medieval iconography of this sort has not been encountered (refer to Figures 32-38 for other examples of ambulant phalli). When comparing these amulets with a first century CE Roman bronze tintinnabula (hanging bell or windchime) excavated from Herculaneum in $1740 \mathrm{CE}$ (Figure 68), the resemblances are striking. The winged tintinnabula has the hindquarters and tail of a lion (its tail is also phallic), a prominent priapic phallus, and a series of bells suspended from the glans, the penis, and the scrotum. Historian John Clarke noted that "combining the male organ with bells doubled its protective power ... and it would have been hung in the house, wherever the owner wanted special protection from malevolent spirits." ${ }^{\text {13 }}$ Tintinnabulae were common features of Roman homes, and three more examples are shown in Figure 69. All share similarities with the previous example, though the wind chimes on the left and right bear an additional priapic rider, mimicking the form of the phallus they are atop.

\footnotetext{
${ }^{12}$ Koldeweij. "Shameless and Naked Images," 500. This has since been refuted, and the two badges have correctly been dated to the period between 1350-1450 CE.

${ }^{13}$ Clarke, Roman Sex, 96. Refer back to the previous discussion on the power of bells and noisemakers to dispel evil, especially with regards to the English examples of apotropaia. (pages 56-59).
} 
Tintinnabulae were not the only form of Roman apotropaic devices, for just as late medieval society had numerous visual images that protected one from the evil eye, so did the Romans. In the mid-second century CE floor mosaic from the House of the Evil Eye in Antioch, shown in Figure 70, one is presented with a marvelous compendium of anti-evil eye imagery. ${ }^{14}$ Placed in the front entryway of the house, and enclosed within a meandering wave border is a priapic dwarf clicking sticks (thereby making apotropaic noise), with his back turned on the evil eye, while his priapic member points directly at the "much-suffering eye." In the central panel of the mosaic, the evil eye is being viciously attacked by a trident, sword, scorpion, centipede, snake, cat, bird, and a dog, who jumps forth from the pierced border, giving the entire mosaic a sense of tension and movement. The Greek inscription at the top humorously warns, "The Same to You."16

The significance of the dwarf is explained by the fact that according to Roman culture, a priapic dwarf was viewed as a comic figure. ${ }^{17}$ Clarke suggested that "in our culture, we are taught not to laugh at ... physical peculiarities ... for the ancient Roman it was perfectly proper to laugh ... laughter [was] the point. For laughter dispels the Evil

${ }^{14}$ Clarke, Roman Sex, 108.

${ }^{15}$ Eunice Dauterman Maguire, Henry P. Maguire, and Maggie J. Duncan-Flowers, Art and Holy Powers in the Early Christian House (Chicago: University of Illinois Press, 1989), 4. The "much-suffering eye" was a common visual device throughout the Mediterranean world. Priapus was the Greek god of livestock, fruit, plants, gardens and the protector of male genitalia. He is consistently depicted in Greek and Roman art with his erect and disproportionately large penis.

${ }^{16}$ Clarke, Roman Sex, 108. See also Elworthy, The Evil Eye, 129-130. He mentioned several other examples where the Evil Eye is attacked by numerous protective animals. One amulet from Roman Gaul (Caylus, France) depicts an eye surrounded by a crocodile, swan, serpent, rooster, dog, lion, a winged phallus, scorpion, and a thunderbolt.

${ }^{17}$ Clarke, Roman Sex, 108. 
Eye."18 Furthermore, as Clarke astutely claimed, "crucial to the humor . . . is the unusual size of their members. The belief that large penises were both ugly and comical stems from the classical Greek definition of the ideal male body type - and its opposite ... big penises, whether in literature or visual representation, are outside the conventional standards of beauty; they represent excess."19 One has only to look at the surviving body of Greek and Roman sculpture to recognize that with exception to apotropaic devices employing priapic figures, males were almost uniformly represented in art with disproportionately small penises (see Figure 71 for one example). Clarke cited as an instructive example Aristophanes' comedy, The Clouds, first performed in 423 BCE. In the play, the character "The Better Argument" is trying to persuade young men to abandon the Sophist school of philosophy by arguing, "if you do these things I tell you ... you will have ... big shoulders ... a big rump and a small prick. But if you follow the practices of youth today, for a start you'll have pale skin ... a small rump, a big dick and a long-winded decree. ${ }^{20}$

A serious examination of classical Greek examples of erotic and phallic apotropaic devices could fill volumes. For the purposes of the present discussion, the analysis of two Greek vases and three tokens from the Netherlands provides a compelling illustration of the relationship existing between their iconographic types. Figures 72-73 show a Greek red-figure vase by the Hasselmann Painter, c. 430-420 BCE, depicting a young woman watering her phallus garden. She is intent on her task, and even seems to smile while undertaking this pleasant task. Figure 74, a pottery shard from a fifth-century

${ }^{18}$ Clarke, Roman Sex, 108. See also Elworthy, The Evil Eye, 143. He noted than one method of averting the evil eye was "by exciting laughter."

${ }^{19}$ Clarke, Roman Sex, 111.

${ }^{20}$ Ibid. 
BCE red-figure vase, depicts a young male carrying a jar of disembodied phalluses. Turning to the tokens from the Netherlands and Low Countries, one begins to see striking similarities between Roman tintinnabulae as well as the Greek vases discussed above. Figure 58 portrays two ambulant phalli with bells descending from their glandes tending a phallus tree. Figures $56-57$ also relate to the garden theme. The badges portray a winged phallus plant with a vulva leaf in one example, while the other reverses the iconography, and is surmounted by a winged vulva. The last badge to serve as an illustrative example is a marvelous compendium of the types of images so far discussed. The token depicted in Figure 49 shows a phallus with its clearly defined ambulatory legs descending from the scrotum. Moreover, the fine detail of the pubic hair gives the impression that the ambulant phallus is wearing pants. The phallus' tail is furthermore composed of eight additional phalli, seeming to sprout from the tail in a vegetal manner. Hunched over into an erect position, the phallus is curiously transporting a female, along with her wheelbarrow full of three disembodied phalli.

It is undeniable upon the visual analysis that iconographical similarities exist between the leaden badges from France, the Netherlands, and Low Countries so far discussed and Greek and Roman examples of apotropaia. This suggests a similar conclusion to that offered by Jennifer Lee, who defined a medieval copy as images with "a loose ... reference to the original." ${ }^{\text {21 }}$ It is unclear, and perhaps always will be, exactly how the late medieval English, French and Dutch artisans became familiar with images of this earlier type. Malcolm Jones' assertion that Roman tintinnabulae were discovered in the Netherlands sometime in the late medieval period is one conceivable mode of

${ }^{21}$ See footnote 190 above. 
transmission, though this does not account for the iconography of the English examples. Also likely - though at the present it is only conjecture - is that the iconographical use of phallic and vulvic images was never lost, and they continued to be popularly produced in European countries that had a history (as most did) of Greco-Roman occupation. What is certain, however, is that the forms express a continuity of iconographic tradition that is unquestionably significant.

Furthermore, given that medieval culture in general was in many ways the descendant of Greco-Roman culture and tradition, it is plausible to assert that in addition to the shared tradition of employed image types, an apotropaic functional relation exists between the late medieval and Greco-Roman examples. There are certainly, however, differences between the examples so far discussed, though the differences do not necessitate a contradiction in ultimate function. For instance, where the Greeks and Romans employed objects of this type on a larger scale, and in the public sphere - on walls of businesses - as well as in the home in masterfully produced decorative items such as vases, wind chimes, and floor mosaics, the late medieval consumers of the phallic badges wore them on their person. Moreover, master craftsman did not produce the badges from the finest metals available. They were cheaply made, mass-produced and intended to provide personal protection from the spread of the Great Mortality for the common man or woman. 


\section{CHAPTER VI}

\section{SUMMARY AND CONCLUSION}

Significantly, the bawdy badges were not the only examples of medieval obscenity. One needs only to conduct a basic search of early and late medieval architecture as well as manuscript illuminations to realize that images of this type were abundant during the period. ${ }^{1}$ Indeed, Nicola McDonald remarked architectural and sculptural details from the majority of late medieval European churches and cathedrals give undeniable evidence to the fact that "graphic representations of sexual organs, human as well as animal and usually in contorted, ludic or aggressive poses, alongside suggestively displayed bums and anal orifices, are reasonably familiar to both professional and amateur medievalists." She noted, however, that "within the secular corpus, badges representing ambulant genitals, [and] detailed sexual scenes ... are

\footnotetext{
' See Michael Camille, Image on the Edge: The Margins of Medieval Art (Cambridge: Harvard University Press, 1992) for a wonderful study of architectural and manuscript obscenities. Also refer to Barbara Freitag, Sheela-Na-Gigs: Unraveling an Enigma (London: Routledge, 2004); Joanne McMahon and Jack Roberts, The Sheela-Na-Gigs of Ireland and Britain: The Divine Hag of the Christian Celts - an Illustrated Guide (Dublin: Mercier Press, 2000); Jørgen Andersen, The Witch on the Wall: Medieval Erotic Sculpture in the British Isles (Copenhagen: Rosenkilde and Bagger, 1977); and Ronald Sheridan and Anne Ross, Gargoyles and Grotesques: Paganism in the Medieval Church (Boston: New York Graphic Society, 1975) for other influential and foundational books on the subject.

${ }^{2}$ McDonald, Medieval Obscenities, 5-6.
} 
without a doubt the most remarkable - for their innovative iconography and pure shock value. ${ }^{3}$

Additionally, it is of utmost importance to remember that the Netherlands, France, and England were some of the hardest hit countries by the Black Death. In the chaos that surrounded the worst years of the plague, people were in reality grasping at straws ancient beliefs in the effectiveness of apotropaic amulets were resurrected. The owners of the evocative badges would have indeed gained solace in believing that they were able to provide themselves and their families some element of protection from the "noxious influences' of the plague. Furthermore, while the main outbreak of the plague lasted less than five years, there continued to be regular outbreaks well into the seventeenth-century. Historian John Kelly observed that after the initial outbreak of 1347-50,

Europe would scarcely know a decade without plague somewhere on the continent. In the Netherlands alone [the country where the highest concentration of the badges has been found] there were epidemics in 1360$62,1362-64,1368-69,1371-72,1382-84,1409,1420-21,1438-39,1450-54$, $1456-59,1466-72,1481-82,1487-90$ and $1492-94{ }^{4}$

This observation makes it difficult not to see a plausible connection between the Black Death and the production beginning c. 1350 , and subsequent decline, c. 1500 , of the bawdy late medieval apotropaic tokens. Local and regional epidemics of the plague, however, had not ceased by c. 1500 , and in fact continued to occur throughout the seventeenth century. One is left wondering, why then, were the badges no longer held as powerful protective devices against the spread of the plague. The answer may in fact, be very simple.

\footnotetext{
${ }^{3}$ Ibid., 7.

${ }^{4}$ Kelly, The Great Mortality, 170.
} 
There is one plausible reason accounting for the tokens sudden disappearance at the beginning of the sixteenth century, one reason that also answers why so many of the badges from England, France, and the Netherlands were deposited into waterways. In 1517, Martin Luther published his 95 Theses, and soon after a religious revolution swarmed across the European continent. The days of Universal Christendom were over. The new Protestant religion called for a break with many of the seemingly superstitious practices of the Roman Catholic Church. Within thirty years, Protestantism had gained a strong foothold in England, France and the Netherlands; the very countries in which the bawdy badges were so popular. Soon, Protestant ministers were calling for an end to all forms of idolatry from their pulpits. Keith Thomas argued that "Protestantism also launched a new campaign against the relics of paganism ... and most Catholic rites were regarded as thinly concealed mutations of earlier pagan ceremonies." ${ }^{5}$ Historian Ronald Finucane cited an excerpt recorded in 1538 by the chronicler of Bishop Shaxton of Salisbury, England, who noted, "images that were used for common pilgrimages bothe in England and Wales were taken downe ... that the people should use noe more idolatrye to them ... all shrines of sainctes were taken downe throughout England." 6

While the above passage refers to religious shrines and images in England, it gives evidence to the period's general tendencies towards Protestant iconoclasm; iconoclasm which spread to personal objects of devotion as well. Brian Spencer lamented that untold numbers of pilgrims' souvenirs were destroyed during this period, and that the "rediscovered souvenirs are modest compensation for the losses sustained at

\footnotetext{
${ }^{5}$ Thomas, Religion and the Decline of Magic, 65 .

${ }^{6}$ Ronald C. Finucane, Miracles and Pilgrims: Popular Belief in Medieval England (New York: St. Martin's Press, 1977), 68. See also Thomas, Religion and the Decline of Magic, 51-76.
} 
the hands of $16^{\text {th }}$ century iconoclasts." ${ }^{97}$ Why, however, were the vast majority of recovered souvenirs, of both a religious as well as a bawdy nature deposited in water sites? Spencer interestingly argued that "age-old superstitions ... may also account for the deposition, perhaps as a propitiatory gesture, of so many pilgrims' souvenirs at rivercrossings ... and for the common practice of folding badges before disposing of them in this way." Rationally, it seems as though it would have been thriftier to melt down the leaden objects for use in other items. The former owners of the religious as well as bawdy badges, however, chose not to do so. This suggests that even though the leaders of the new Protestant religion deemed the badges idolatrous, to their former owners who freely chose to discard the items, the tokens still embodied powerful magic that could not be disposed of lightly.

While this essay has addressed many questions pertaining to the advanced study of the bawdy badges, many more questions remain. Hopefully, future scholarship on these enigmatic objects will continue to expand the current knowledge base surrounding the bawdy badges, as well as offer, in a meaningful way, important new areas of scholarship. Arguably, many of the bawdy badges raise fundamental questions about the changing nature of gender issues during their period of production. For instance, Figure 1, 'Pussy Goes A' Hunting' portrays an armed and mounted vulva, clearly in a powerful gender role. Moreover, Figure 2 illustrates a pudendum roasting a penis on a spit. Other related amulets show female genitalia in similar powerful roles, roles that lead one to

\footnotetext{
${ }^{7}$ Spencer, Pilgrims' Souvenirs, 24.

${ }^{8}$ Ibid., 18. The early ancestors of the regions of England, France, and the Netherlands were the ubiquitous Celts, whom, it is well known, purposefully bent or marred votive objects before placing them as offerings in rivers and water sites. This practice is perhaps what Spencer refers to.
} 
assume that between c. 1350-1500 CE, late medieval society was experiencing changing concepts of gender and gender roles. Related to questions of gender and changing gender roles that the bawdy badges give rise to, is the fact that while it has been established to a fairly certain degree that the late medieval tokens are related in significant iconographic ways to earlier Greek and Roman examples of apotropaia, the much older material contains no known examples of female genitalia employed iconographically on apotropaic objects. Why the late medieval artisans of the badges were innovative in such a manner is unclear and it would be an interesting and important area of scholarship to be examined.

This essay gives rise to other possible areas of scholarship that could be explored, such as, advanced studies into medieval theories of sight and sight transmission of disease. For the evil eye, which is commonly thought to be a purposeful and malignant force, and sight contagion, which infected victims by mere circumstance, and was not considered purposeful, are significant differences that need to be further explored. Medieval and early modern medical texts and treatises would perhaps shed light on the distinction. Furthermore, an advanced treatment of interpretive theory, which was outside the scope of the present discussion, would lend weight to examination of meaning and function of the bawdy badges analyzed throughout the body of this essay (see footnote 46 for a listing of useful sources).

This essay has analyzed and discussed a broad range of historical topics. Chapter 1 outlined the general topic, as well as discussing the need for expanded scholarship and examination of the previously misunderstood secular items. Chapter 2 discussed the available historiographic literature on the topic, and noted areas of research that provide 
impetus for further study, as well as secondary sources that provide questionable interpretations. Chapter 3 examined the broader aspects of the Great Mortality, as well as the learned, professional medical responses. Chapter 4 examined the secular badges from England, France, the Low Countries, and the Netherlands within the broader context of pilgrimage souvenirs. Chapter 5 outlined the argument for historical iconographical antecedents of the tokens. In so doing, arguably a greater comprehension of this enigmatic class of artifacts has been found. Owing to the sexual depictions on many of the bawdy amulets, scholars in the past have shied away from their study, thereby doing a great injustice to the understanding of these items. For, not only are "pilgrims" souvenirs ... among the most picturesque and evocative artefacts to emerge from the archaeological exploration of medieval urban sites," but also their function provided much-needed relief from the perceived threat of the evil eye. ${ }^{9}$ And as historian Jonathan Clark suggested, "if these images seem to us to be in bad taste ... it is because we live in a world dominated by rational explanations of evil," as well as a world that no longer experiences devastating outbreaks of the Black Death. ${ }^{10}$

\footnotetext{
${ }^{9}$ Spencer, Pilgrim Souvenirs, 24.

${ }^{10}$ Clarke, Roman Sex, 112.
} 

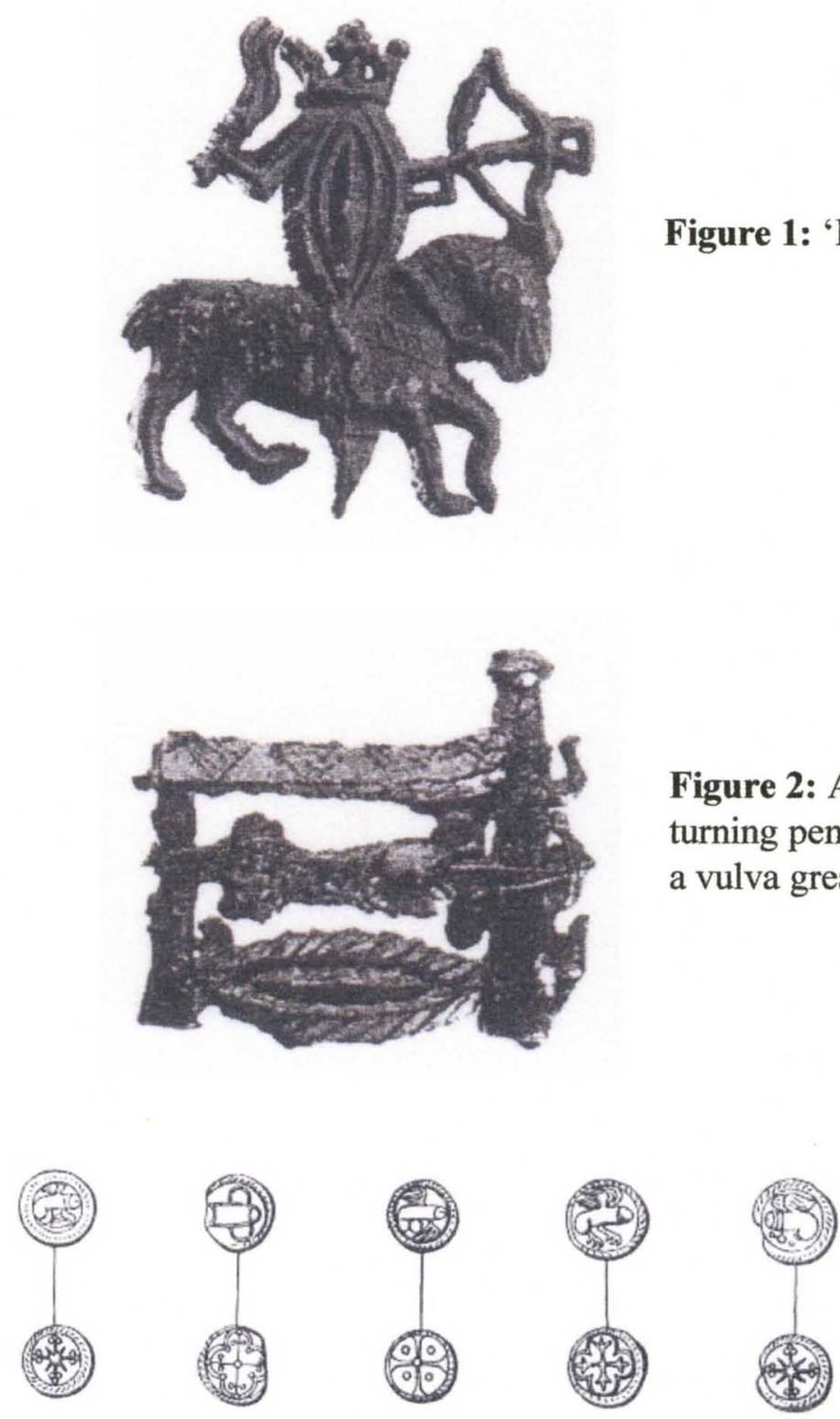

Figure 3: Ten tokens from the Seine

Figure 2: Ambulant pudendum turning penis on roasting spit over a vulva grease trap
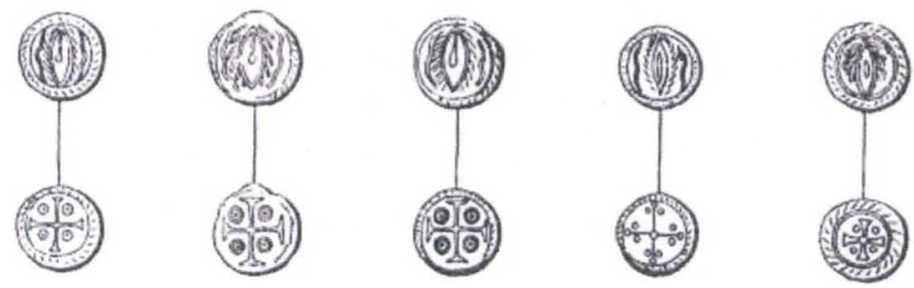


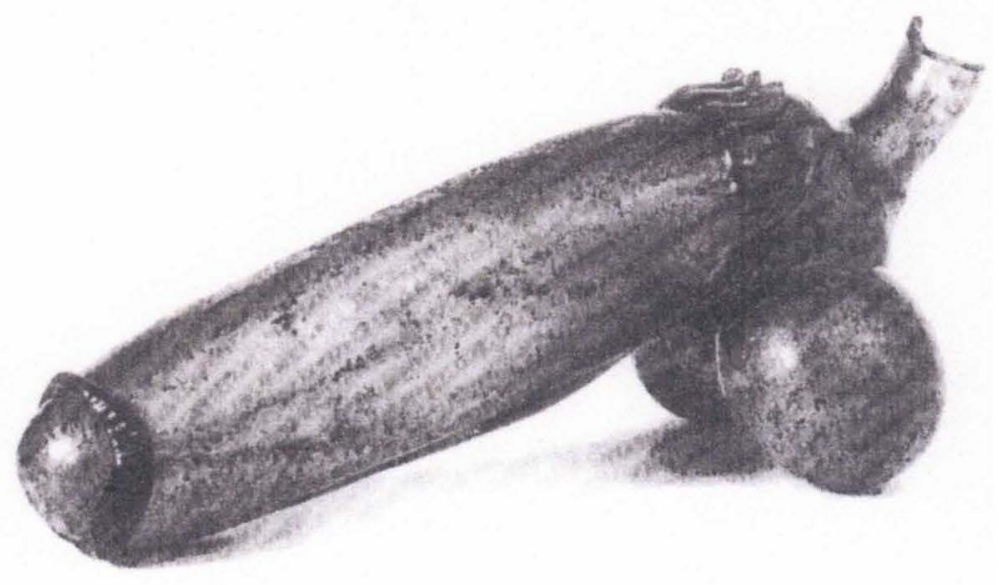

Figure 4: German phallovitroboli (phallus drinking glass), c. 1500.

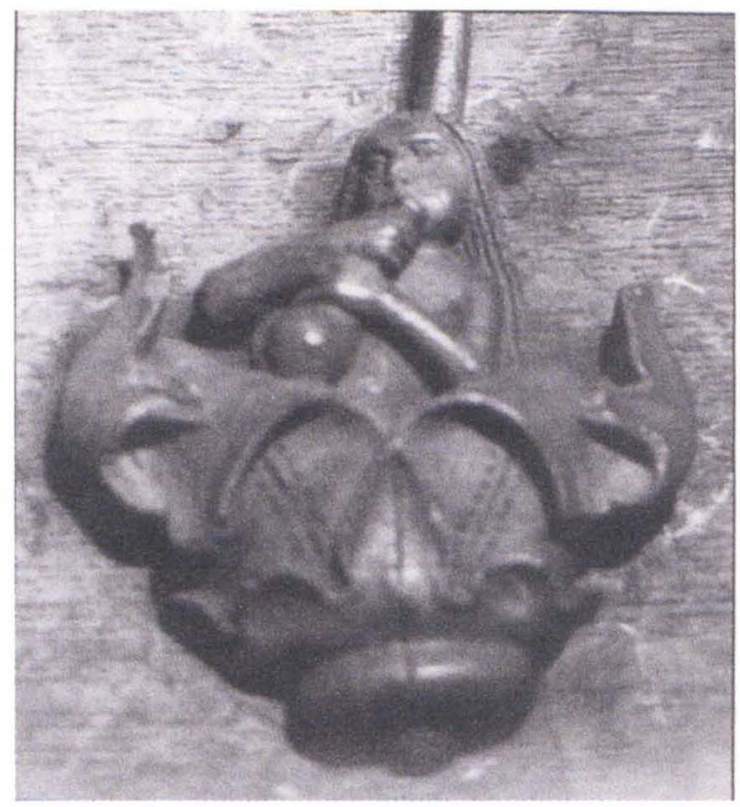

Figure 5: Misericord from Bristol Cathedral, showing a woman drinking from a phallovitroboli, c. 1520 


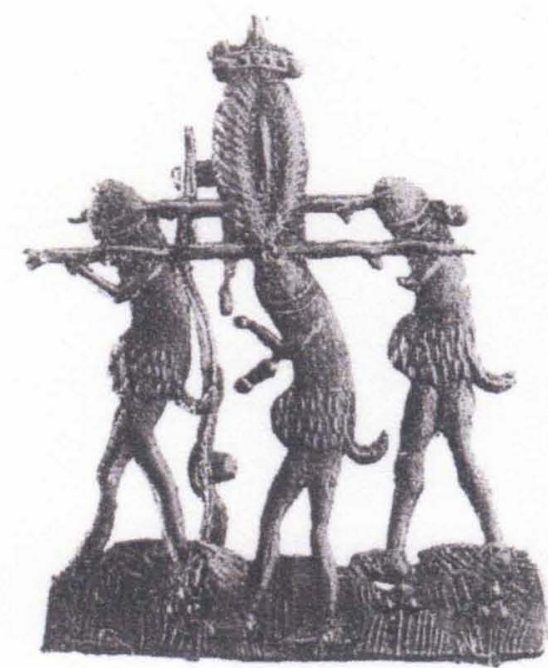

Figure 6: Ambulant phalli carrying crowned vulva on a processional bier

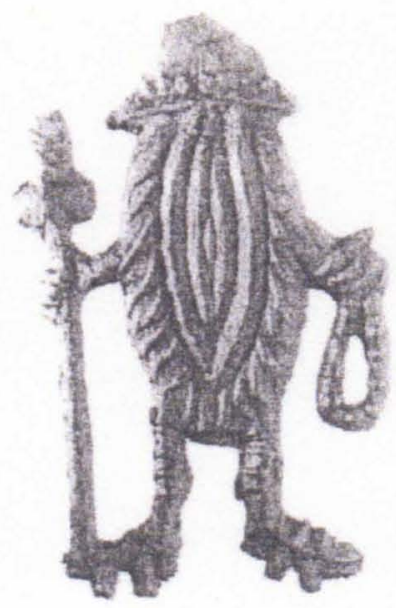

Figure 7: Pudendum Pilgrim

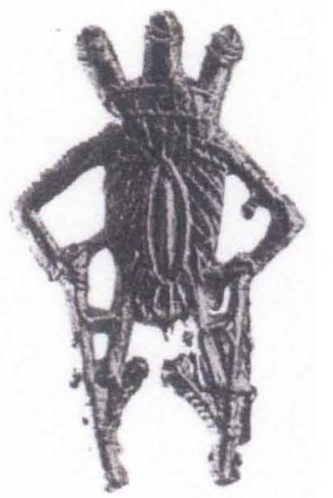

Figure 8: Ambulant pudendum walking on stilts wearing a phallus crown 


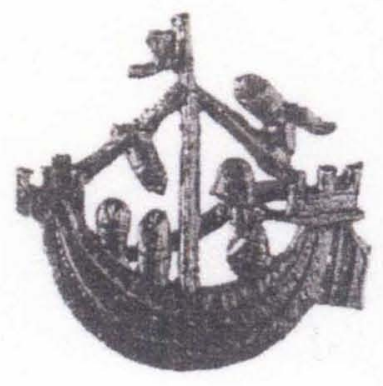

Figure 9: Ambulant phalli

manning a sailing vessel

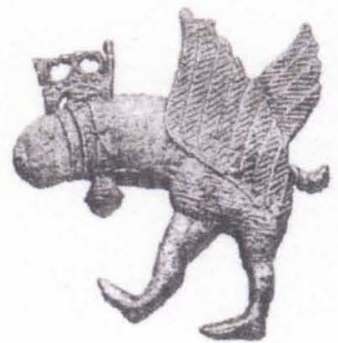

Figure 10: Ambulant phallus wearing bell and crown

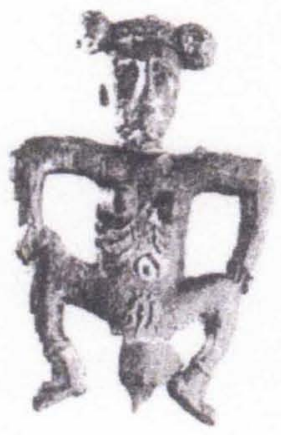

Figure 11: Sheela-Na-Gig badge

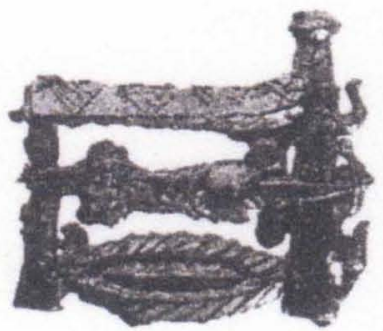

Figure 12: Ambulant pudendum turning penis on a roasting spit over a vulva grease trap 
Figure 13: Pudendum climbing a ladder

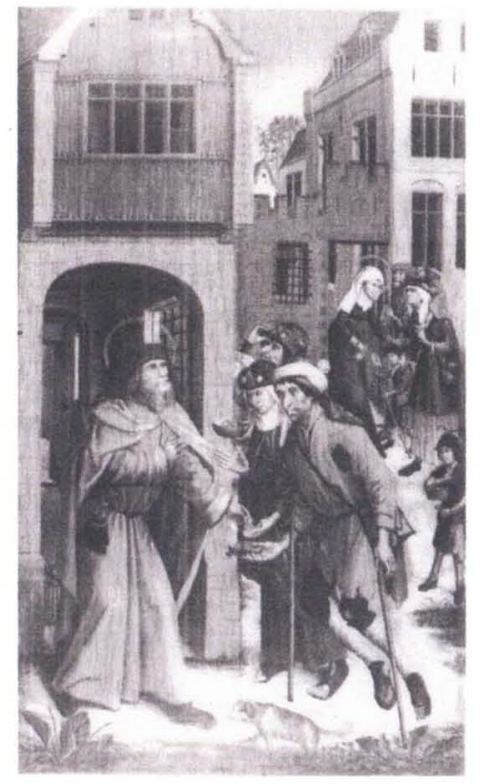

Figure 14: Flemish altarpiece, c. 1490 showing pilgrims wearing badges
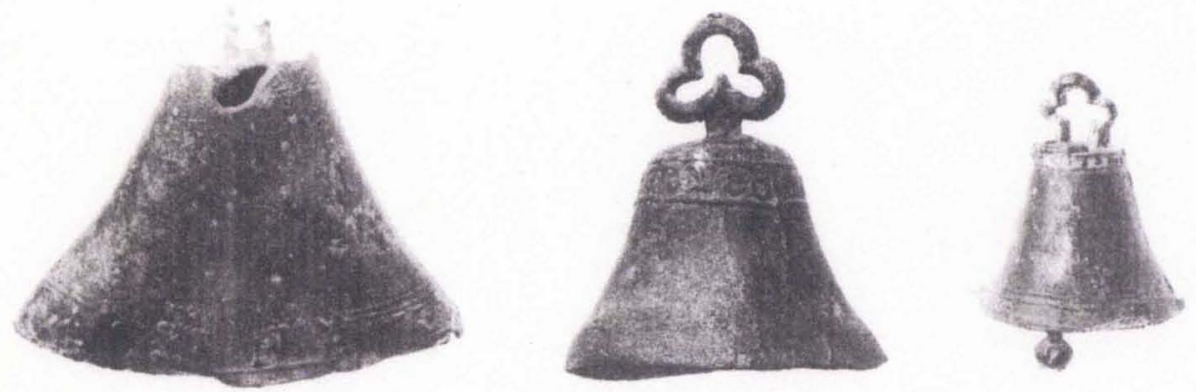

Figure 15: Three 'Canterbury Bells 

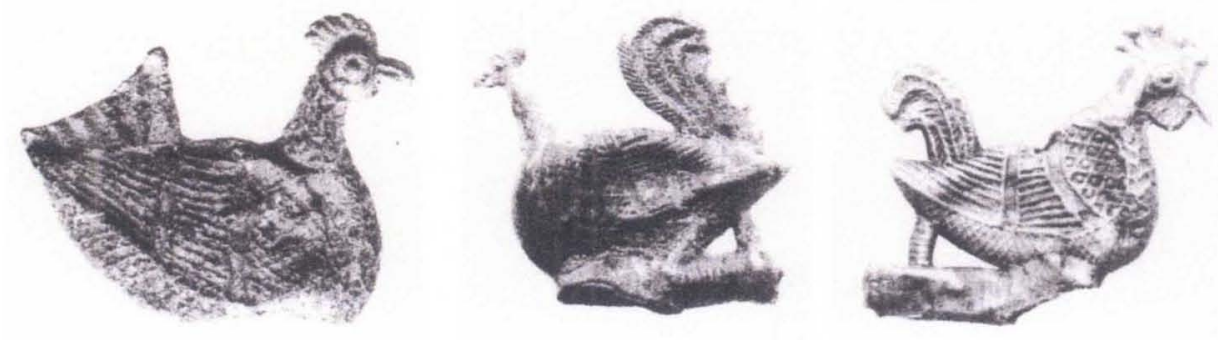

Figure 16: Three examples of pilgrims' whistles

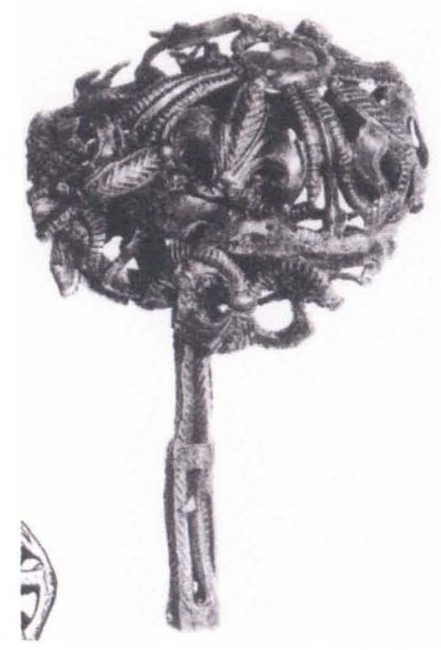

Figure 17: (left) Fret-worked pewter rattle

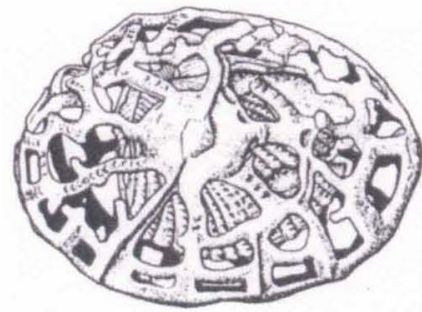

Figure 18: (below) Fragment of rattle with intact noisemaker
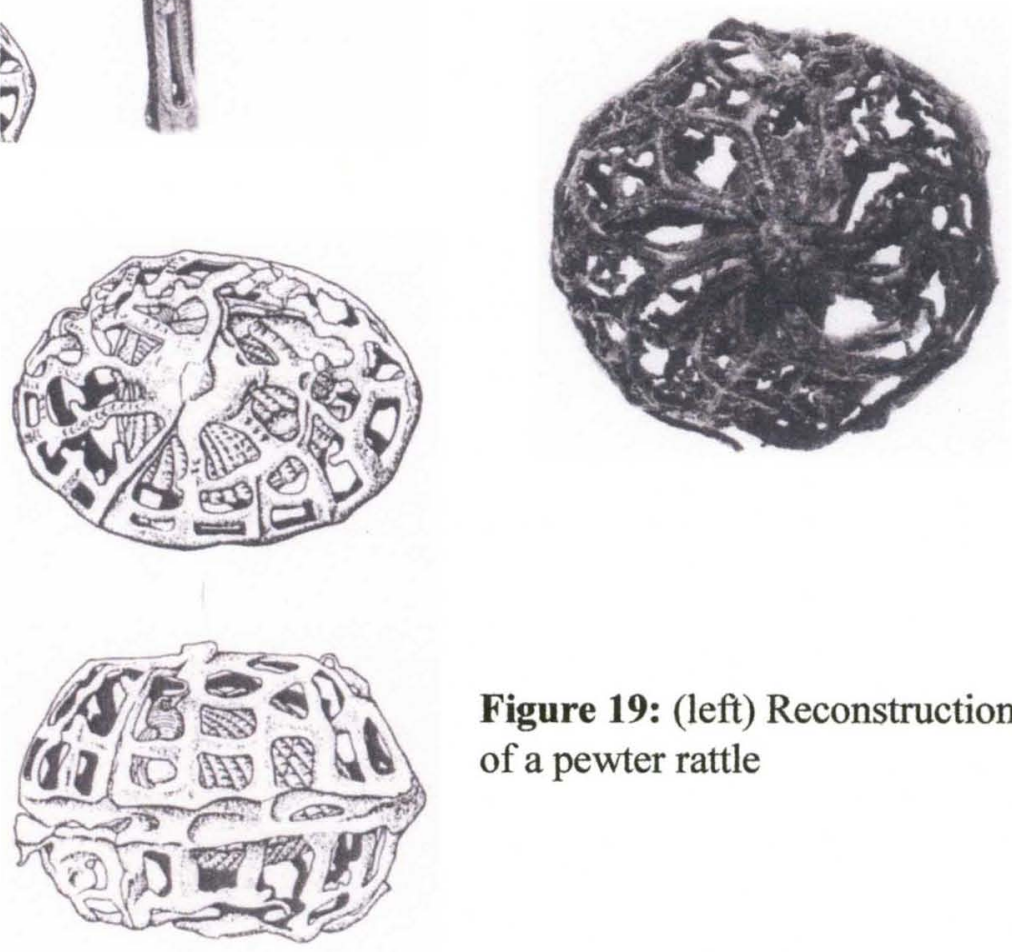

Figure 19: (left) Reconstruction drawing of a pewter rattle 

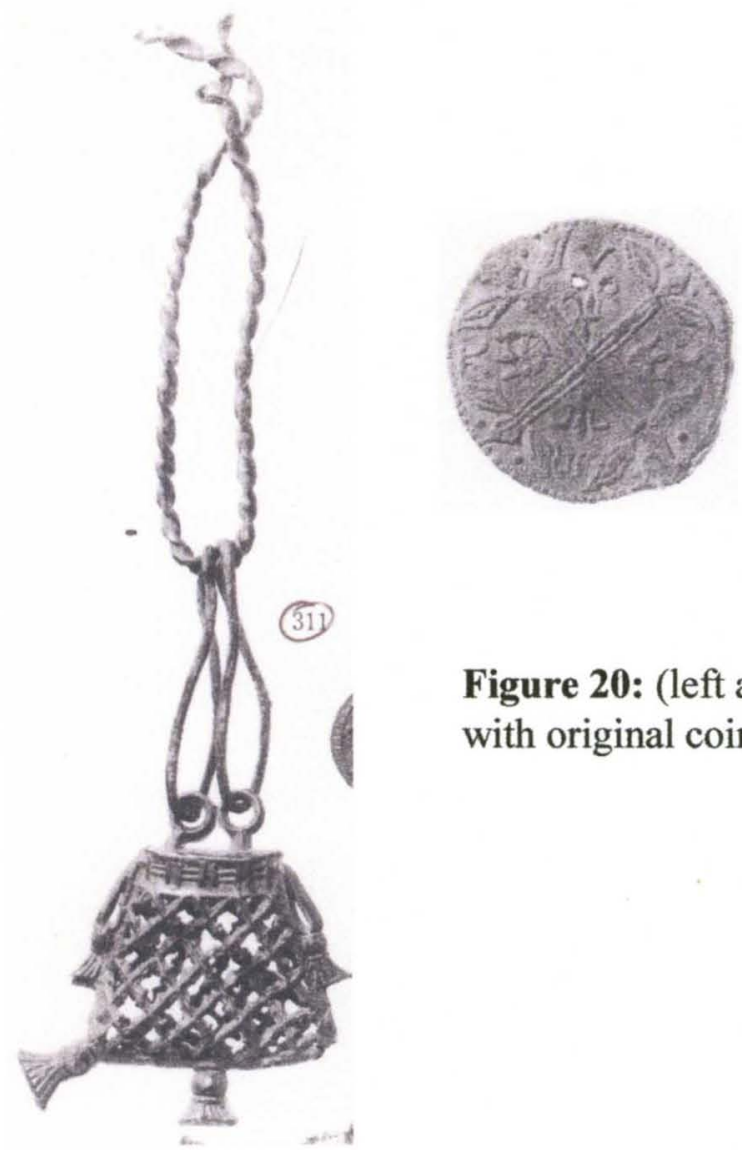

Figure 20: (left and above) Purse pendant with original coin housed within

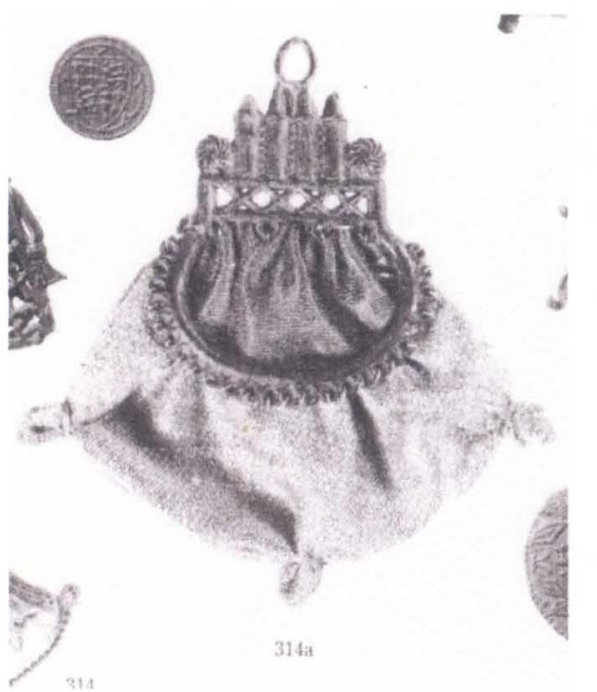

Figure 21: Purse pendant with reconstructed bag 


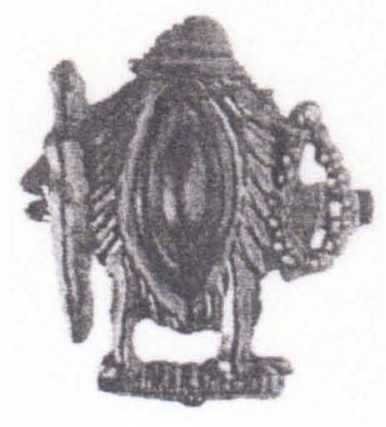

Figure 22: Pudendum pilgrim

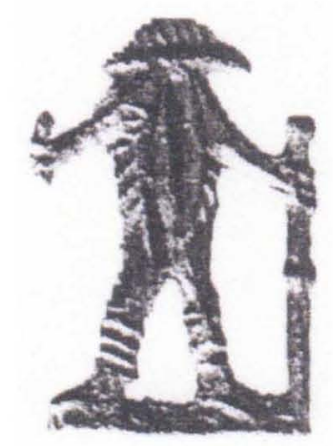

Figure 23: Pudendum pilgrim

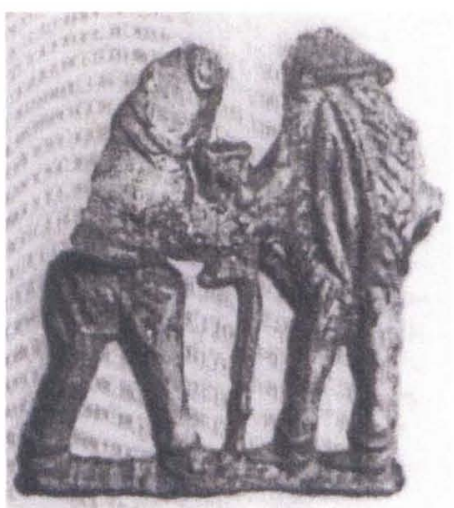

Figure 24: Pudendum and Phallus pilgrims

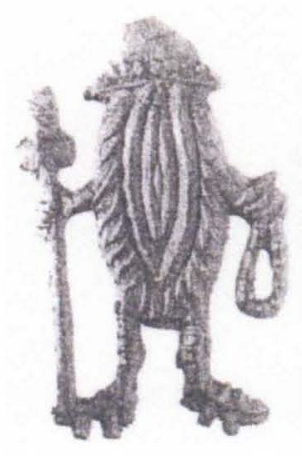

Figure 25: Pudendum pilgrim 


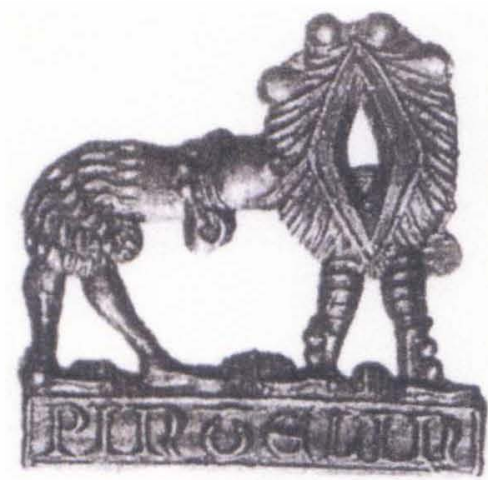

Figure 26: 'Pintelin' badge

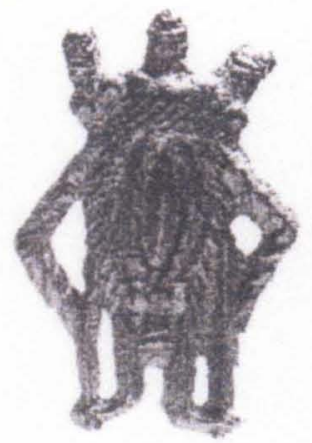

Figure 27: Pudendum on stilts with phallus crown

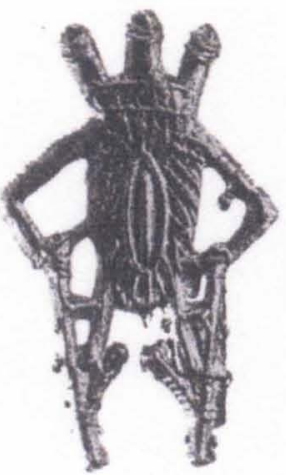

Figure 28: Pudendum on stilts with phallus crown

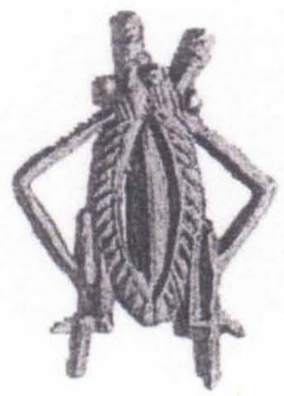

Figure 29: Pudendum on stilts with phallus crown 


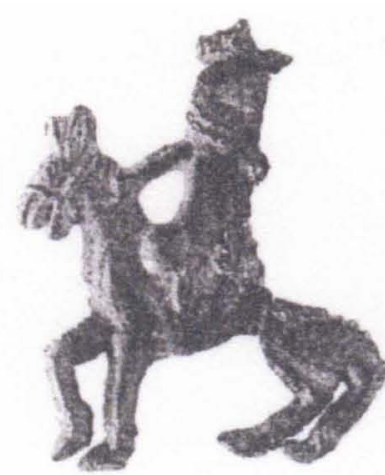

Figure 30: Phallus riding a donkey or horse

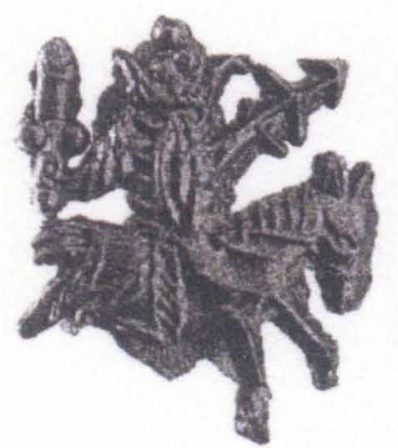

Figure 31: A second 'Pussy Goes A' Hunting'

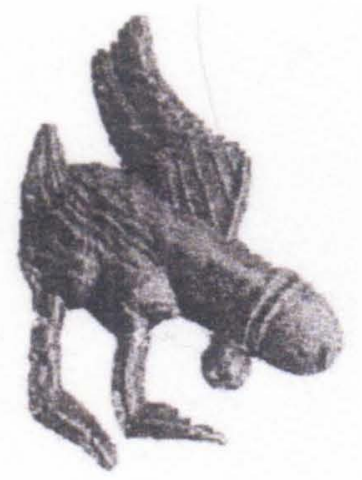

Figure 32: Ambulant winged phallus with bell

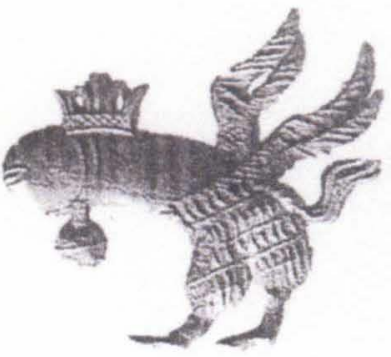

Figure 33: Ambulant winged phallus wearing crown and bell 


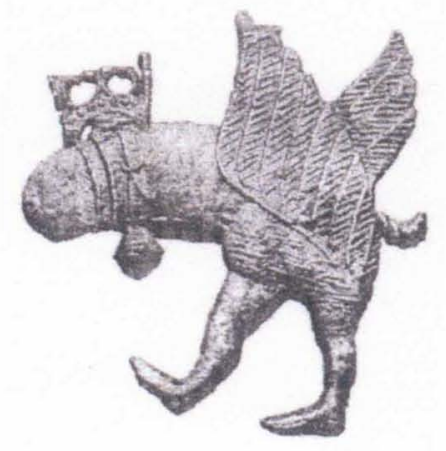

Figure 34: Ambulant winged phallus wearing crown and bell

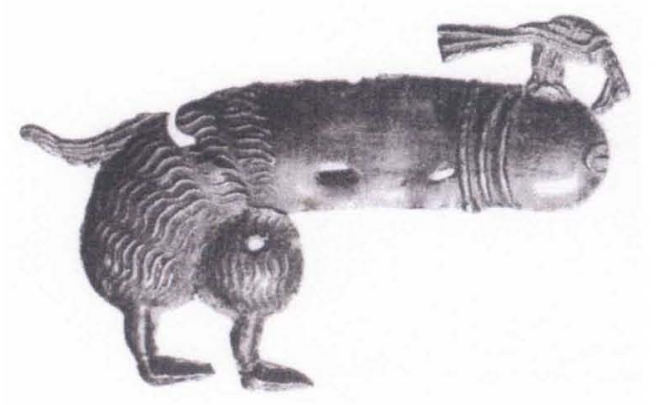

Figure 35: Ambulant phallus with perching bird

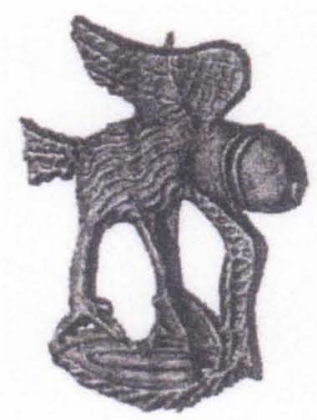

Figure 36: Ambulant winged

phallus standing on a vulva

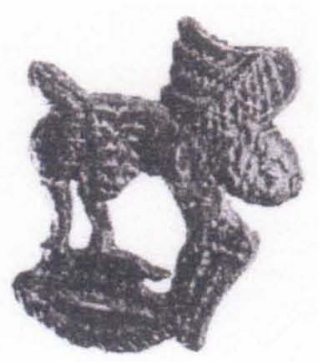

Figure 37: Ambulant winged

phallus standing on a vulva 


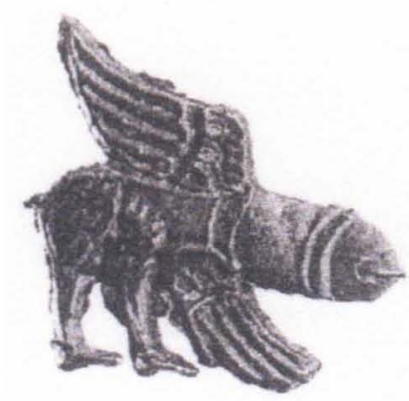

Figure 39: Ambulant winged phallus

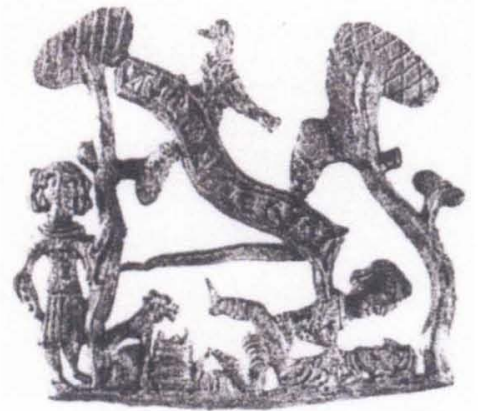

Figure 39: Couple having sex while a man and a dog watch

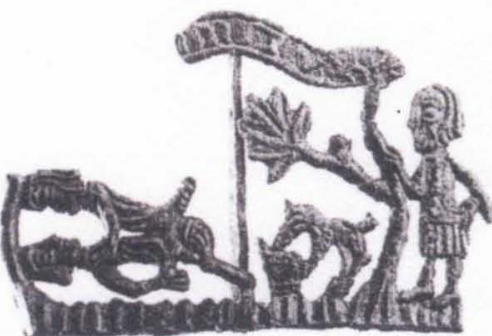

Figure 40: Couple having sex while man and dog watch

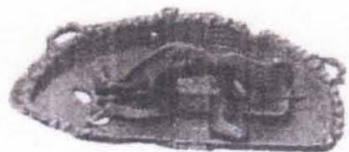

Figure 41: Couple having sex on a clam shell
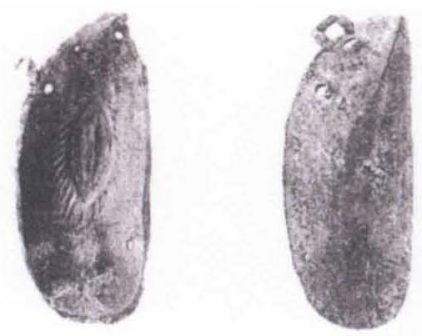

Figure 42: Clam shell locket with hidden vulva 


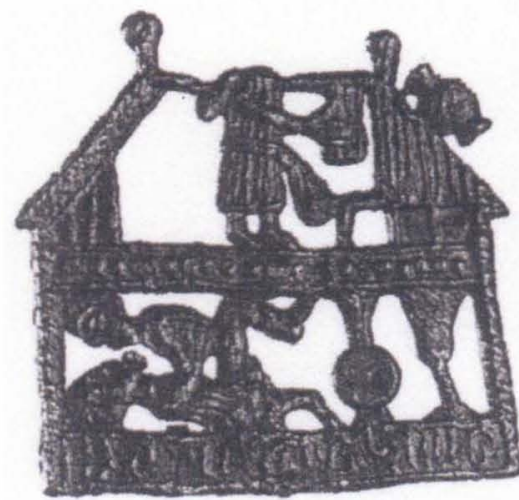

Figure 43: Couple having sex in a tavern

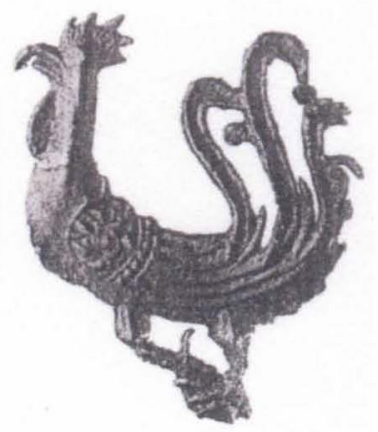

Figure 44: Cock badge

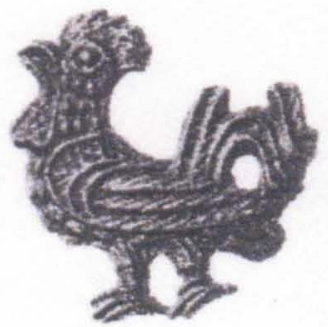

Figure 45: Cock badge

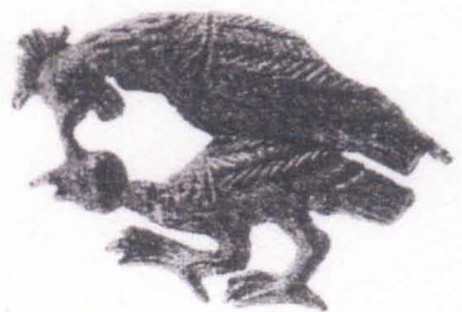

Figure 46: Cock and hen having sex 


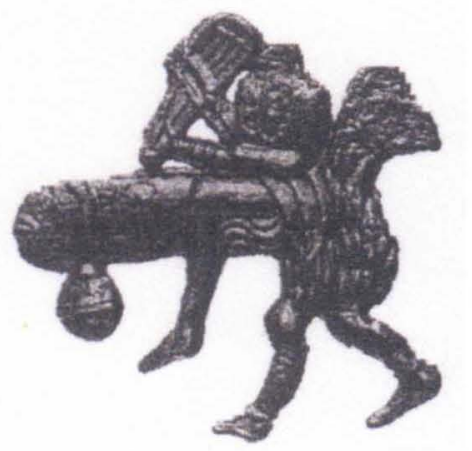

Figure 47: Troubadour playing harp while riding on back of ambulant winged and belled phallus

Figure 48: Man riding ambulant winged and belled phallus

Figure 49: Woman pushing phallus-filled wheelbarrow on back of ambulant phallus

Figure 50: Man pushing wheelbarrow on back of ambulant phallus 


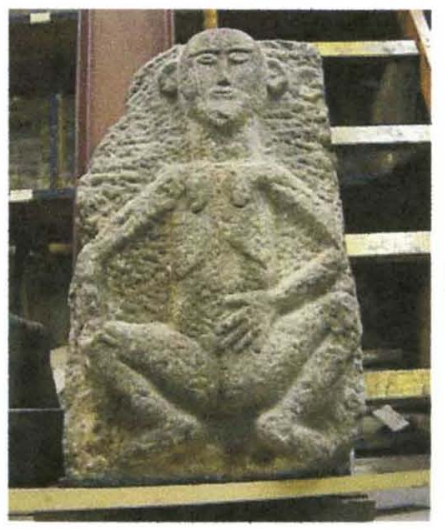

Figure 51: Irish Sheela-Na-Gig

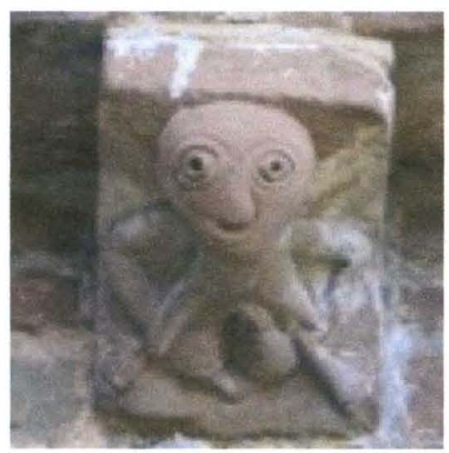

Figure 52: The Kilpeck Sheela-Na-Gig

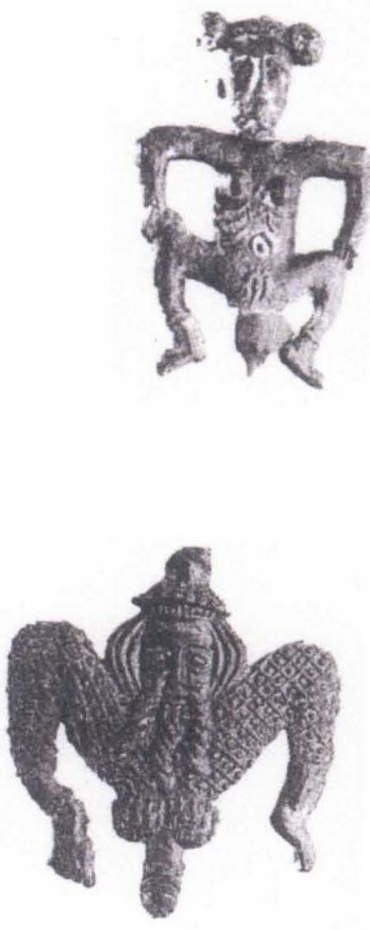

Figure 53: (left) Sheela-Na-Gig badge

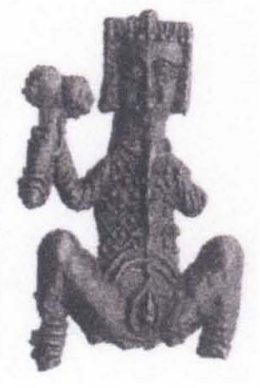

Figure 54: (left) Sheela-Na-Gig holding a penis

Figure 55: Male Sheela-Na-Gig with protruding phallus 
Figure 56: Winged phallus and pudendum plant

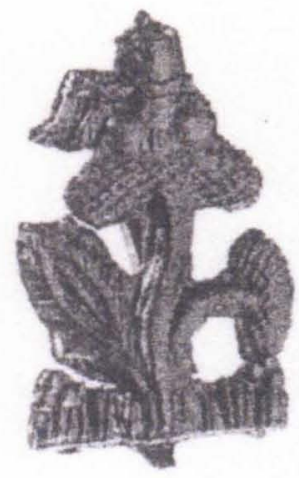

\section{rigure 56: Winged phallus and pudendum plant}

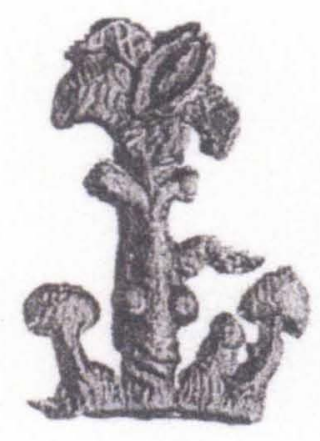

Figure 57: Winged pudendum and phallus plant

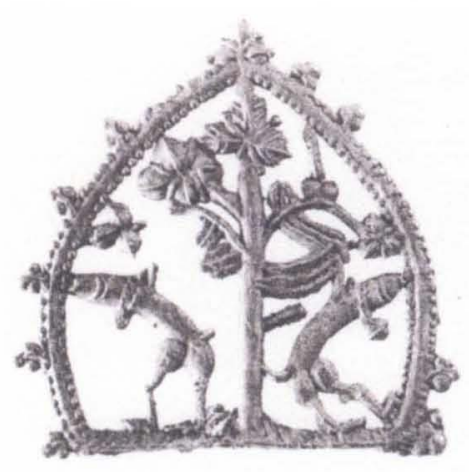

Figure 58: Ambulant phalli

tending penis tree

Figure 59: Pudendum climbing a ladder 
Figure 60: (left) Phallus pendant

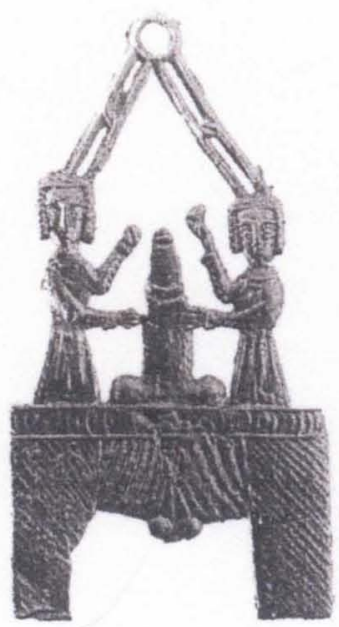

Figure 61: Women

forging phallus

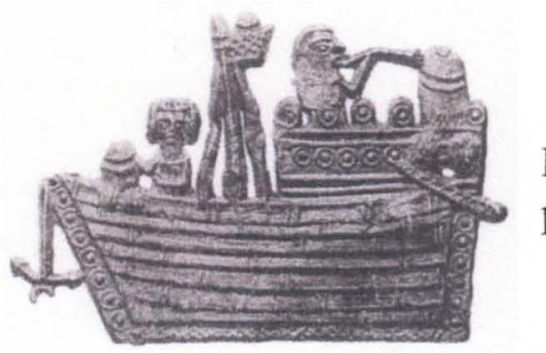

Figure 62: Men and ambulant

phalli manning a ship

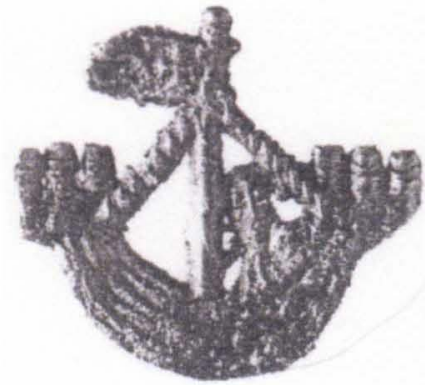

Figure 63: Ambulant phalli manning a ship 


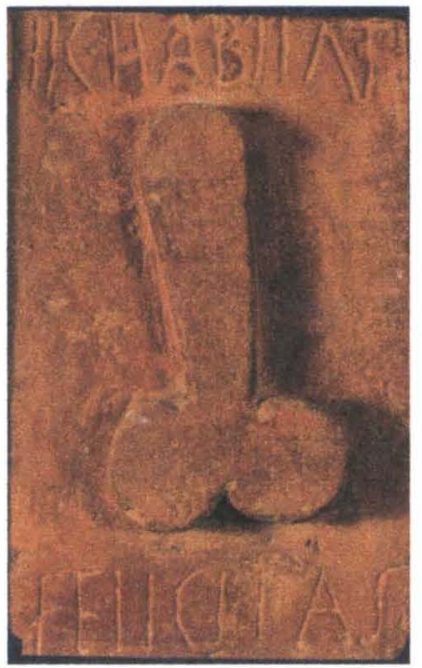

Figure 64: 'HIC HABITAT FELICITAS'

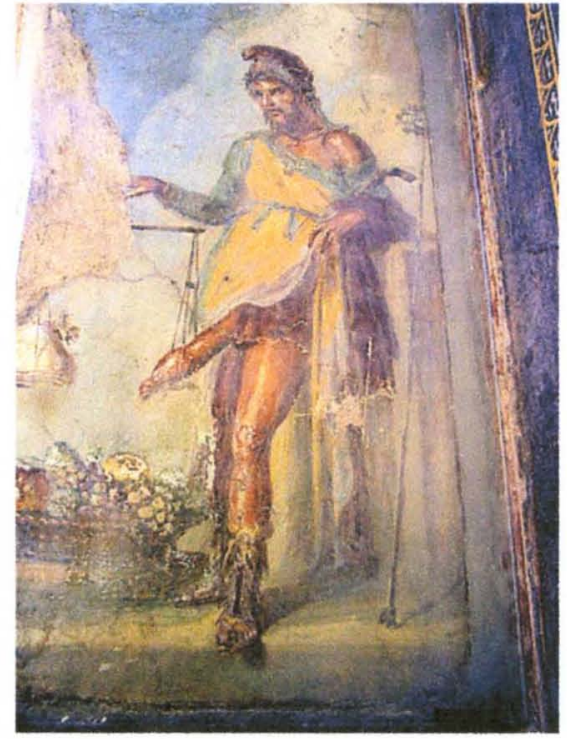

Figure 65: Fresco of Priapus from the House of the Vettii, Pompeii

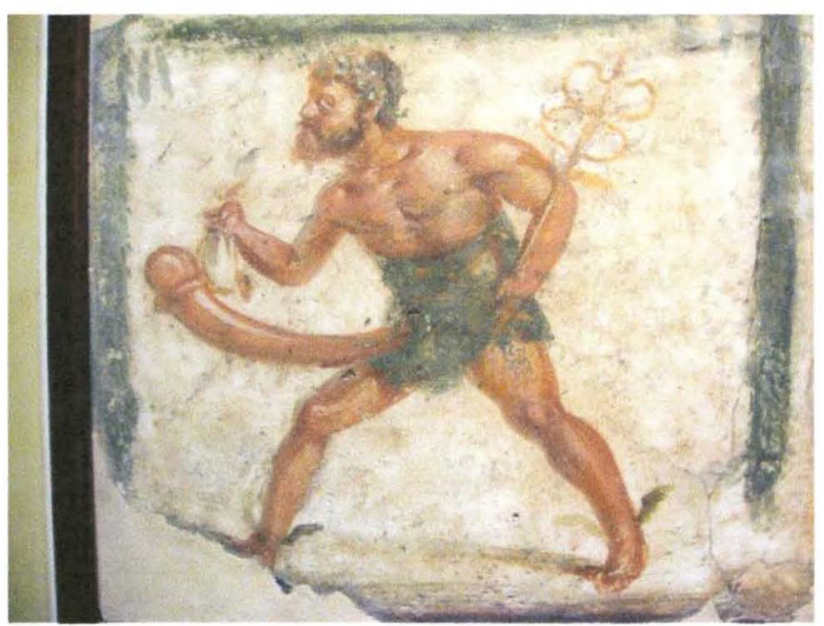

Figure 66: Priapic Mercury fresco, Pompeii 

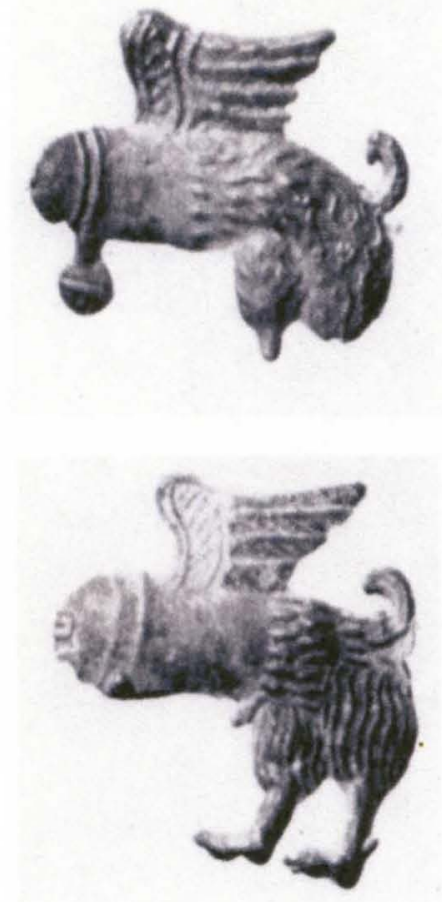

Figure 67: (above) Two ambulant winged phalli

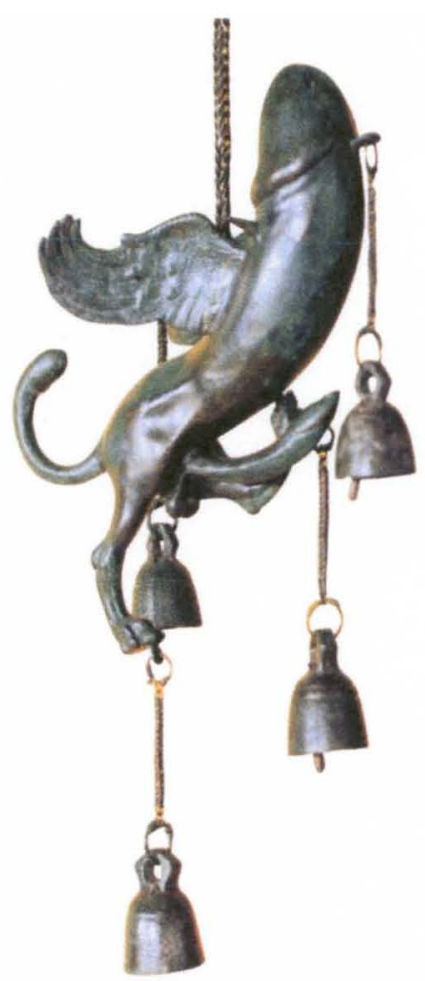

Figure 68: (above) 1st century CE Roman bronze Tintinnabula from Herculaneum

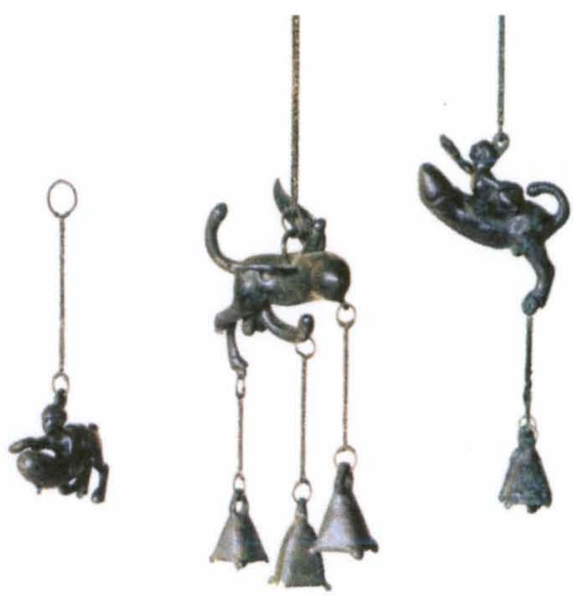

Figure 69: Three 1st century CE Roman bronze Tintinnabulae 


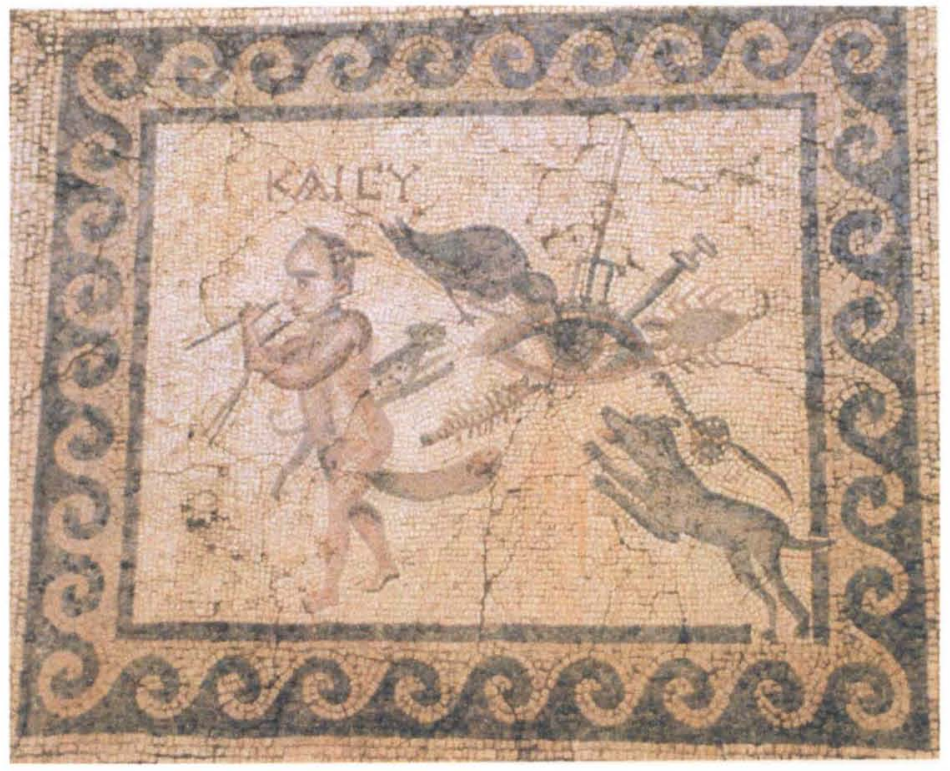

Figure 70: (above) Entryway mosaic from the House of the Evil Eye, Antioch, c. $150 \mathrm{CE}$

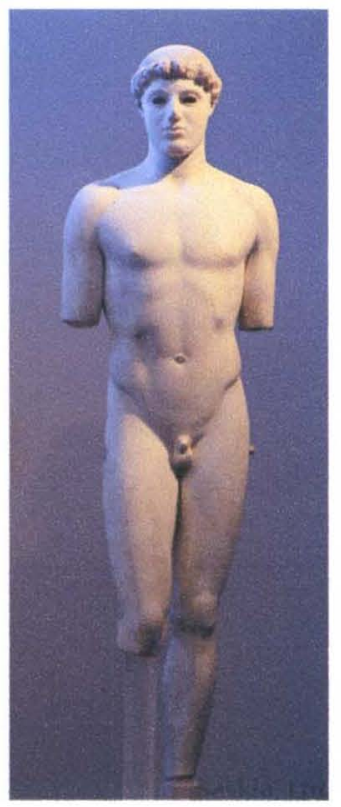

Figure 71: Archaic Greek sculpture of a young male 

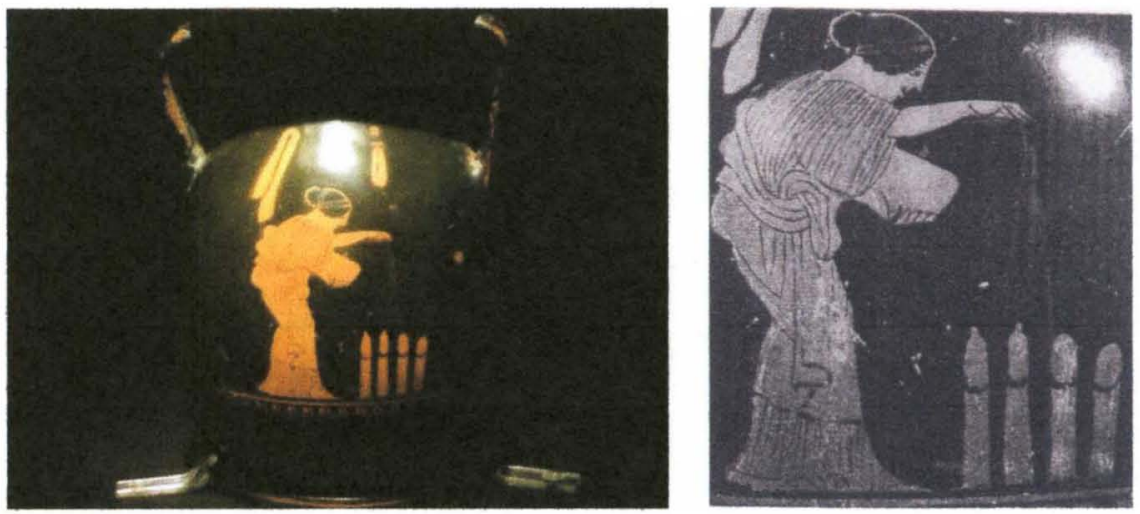

Figures 72 \& 73: Greek vase c. $430-420$ BCE by the Hasselmann Painter depicting a young woman watering her phallus garden

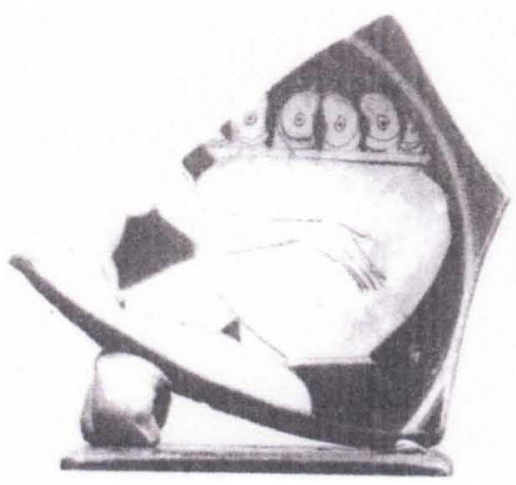

Figure 74: Fragment of a Greek vase depicting a male youth carrying a jar of disembodied phalluses $\mathrm{c}$. 5 th century BCE 


\section{REFERENCES}

\section{Primary Sources:}

Albertus Magnus, De animalibus (Books 22-26). Translated by James J. Scanlan.

Binghamton, New York: Medieval and Renaissance Texts and Studies, 1987.

Boccaccio, Giovanni. The Decameron. Translated by Mark Musa and Peter Bondanella. New York: Penguin Books, 2002.

Clyn, John. Annalium hiberniae chronicon. Translated and edited by R. Butler. Dublin: Irish Archaeological Society, 1849.

Institoris, Heinrich, and Jakob Sprenger. The Malleus Malificarum. Translated and Edited by P. G. Maxwell-Stuart. Manchester: Manchester University Press, 2007.

Juvenal, The Sixteen Satires. Translated by Peter Green. London: Penguin Books, 1998.

Ogden, Margaret Sinclair, ed. The Cyrugie of Guy de Chauliac, Vol. 1. London: Early English Text Society; Oxford University Press, 1971.

, ed. The 'Liber de diversis medicinnis' in the Thornton Manuscript. 1938. Revised Reprint, London: Early English Text Society; Oxford University Press, 1969.

Pliny, Natural History. Translated by Philemon Holland. Carbondale, IL.: Illinois University Press, 1962.

Shakespeare, William. Love's Labour's Lost. Edited by G. R. Hibbard. Oxford: Clarendon Press, 1990.

\section{Secondary Sources:}

Articles and Chapters in Books:

Aston, Margaret. "Death." In Fifteenth-Century Attitudes: Perceptions of Society in Late Medieval England, edited by Rosemary Horrox, 202-29. Cambridge: Cambridge University Press, 1994.

Bruna, Denis. "Medieval Sexual Badges, Amulets and Tokens: Arthur Forgeais and Some Notes on His Life and Discoveries." translated extract from "Enseignes $d u$ 


\section{Pélerinage et Esignes Profanes."}

www. menantolstudio. freeserve.co.uk/forgeais. htm.

Colantuono, Anthony. "The Penis Possessed: Phallic Birds, Erotic Magic, and Sins of the Body, ca. 1470-1500.” In The Body in Early Modern Italy, edited by Julia L. Hairston and Walter Stephens, 92-108. Baltimore: The Johns Hopkins University Press, 2010.

Davis, Natalie Zemon. "Women on Top." In Society and Culture in Early Modern France: Eight Essays by Natalie Zemon Davis, 124-151. Stanford, CA.: Stanford University Press, 1975.

. "The Reasons of Misrule: Youth Groups and Charivaris in Sixteenth-Century France." In Past \& Present 50 (February, 1971): 41-75.

Durand, John D. "Historical Estimates of World Population: An Evaluation," Population and Development Review 3 (September 1977): 253-296.

Easton, Martha. "Was it Good for You, Too?: Medieval Erotic Art and Its Audiences." Different Visions: A Journal of New Perspectives on Medieval Art, Issue 1 (September 2008): 1-30.

Friedman, John B. "He Hath a Thousand Slayn this Pestilence: The Iconography of the Plague in the Late Middle Ages." In Social Unrest in the Late Middle Ages: Papers of the $15^{\text {th }}$ Annual Conference of the Center for Medieval and Early Renaissance Studies, edited by Francis X. Newman, 75-112. Binghamton, NY.: State University of New York at Binghamton, 1986.

Koldeweij, Jos. "Shameless and Naked Images: Obscene Badges as Parodies of Popular Devotion," in Art and Architecture of Late Medieval Pilgrimage in Northern Europe and the British Isles, edited by Sarah Blike and Rita Tekippe, 493-510. Boston: Brill, 2005.

Krautheimer, Richard. "Introduction to an Iconography of Medieval Architecture." Journal of the Warburg and Courtauld Institutes 5 (1942): 1-33.

Lee, Jennifer. "Beyond the Locus Sanctus: The Independent Iconography of Pilgrims' Souvenirs." Visual Resources 21, no.4 (2005): 363-381.

Michon, Joseph L. A. Documents inédits sur la grande peste de 1348, thése pour le doctorat en médicine. (Paris, 1860). 46-52. Quoted in Rosemary Horrox, The Black Death (New York: Manchester University Press, 1994), 182.

Olsen, Vibeke. "The Significance of Sameness: An Overview of Standardization and Imitation in Medieval Art." Visual Resources 20, nos. 2-3 (2004): 161-178. 
Rawcliff, Carol. "Curing Bodies and Healing Souls: Pilgrimage and the Sick in Medieval East Anglia." In Pilgrimage, edited by Colin Morris and Peter Roberts, 108-40. Cambridge: Cambridge University Press, 2002.

\section{Secondary Sources:}

Books:

Aberth, John. From the Brink of the Apocalypse: Confronting Famine, War, Plague, and Death in the Later Middle Ages. New York: Routledge, 2001.

. The Black Death: The Great Mortality of 1348-1350: A Brief History with Documents. Boston: Bedford/St. Martin's. 2005.

Andersen, Jørgen. The Witch on the Wall: Medieval Erotic Sculpture in the British Isles. Copenhagen: Rosenkilde and Bagger, 1977.

Arnold, John H. Belief and Unbelief in Medieval Europe. London: Hodder Education, 2005.

Bakhtin, Mikhail. Problems of Dostoevsky's Poetics. Translated and Edited by Caryl Emerson. Minneapolis, MN.: University of Minnesota Press, 1984. . Rabelais and His World. Translated by Helene Iswolsky. Cambridge, Mass.: Massachusetts Institute of Technology Press, 1968.

Blick, Sarah, and Rita Tekippe, eds. Art and Architecture of Late Medieval Pilgrimage in Northern Europe and the British Isles: Plates. Boston: Brill, 2005.

Burke, Peter. Popular Culture in Early Modern Europe. $3^{\text {rd }}$ ed. Burlington, VT.: Ashgate, 2009.

Byrne, Joseph P. The Black Death. Westport, Conn.: Greenwood Press, 2004.

Camille, Michael. Image on the Edge: The Margins of Medieval Art. Cambridge: Harvard University Press, 1992.

Chazelle, Celia M., ed. Literacy, Politics, and Artistic Innovation in the Early Medieval West: Papers Delivered at 'A Symposium on Early Medieval Culture, 'Bryn Mawr College. Lanham, Maryland: University Press of America, 1992.

Clarke, John R. Roman Sex: 100 B.C.-A.D. 250. New York: Harry N. Abrams, 2003.

Cohn, Samuel K., Jr. The Black Death Transformed: Disease and Culture in Early Renaissance Europe. New York: Arnold Publishers, 2002. 
Dentith, Simon. Bakhtinian Thought: An Introductory Reader. London: Routledge, 1995.

Elworthy, Frederick. The Evil Eye: The Origins and Practices of Superstition. 1895. Reprint, New York: The Julian Press, 1958.

Finucane, Ronald C. Miracles and Pilgrims: Popular Belief in Medieval England. 1977. Reprint, New York: St. Martin's Press, 1995.

Flint, Valerie I. J. The Rise of Magic in Early Medieval Europe. Princeton, NJ.: Princeton University Press, 1991.

Freitag, Barbara. Sheela-Na-Gigs: Unraveling an Enigma. London: Routledge, 2004.

Gottfried, Robert S. The Black Death: Natural and Human Disaster in Medieval Europe. New York: The Free Press, 1983.

Gurevich, Aron. Medieval Popular Culture: Problems of Belief and Perception. Translated by János M. Bak and Paul A. Hollingsworth. Cambridge: Cambridge University Press, 1988.

Harris, Stephen J., and Byron L. Grigsby, eds. Misconceptions About the Middle Ages. New York: Routledge, 2008.

Herlihy, David. The Black Death and the Transformation of the West. Cambridge: Harvard University Press, 1997.

Horrox, Rosemary, ed. Fifteenth-Century Attitudes: Perceptions of Society in Late Medieval England. Cambridge: Cambridge University Press, 1994.

. The Black Death. New York: Manchester University Press, 1994.

Huizinga, Johan. The Autumn of the Middle Ages. Translated by Rodney J. Payton and Ulrich Mammitzsch. Chicago: University of Chicago Press, 1996.

. Homo Ludens: A Study of the Play-Element in Culture. New York: Roy Publishers, 1950.

Humphrey, Chris. The Politics of Carnival: Festive Misrule in Medieval England. Manchester: Manchester University Press, 2001.

Huppert, George. After the Black Death: A Social History of Early Modern Europe. $2^{\text {nd }}$ ed. Bloomington, IN.: Indiana University Press, 1998.

Hyman, Timothy, and Roger Malbert. Carnivalesque. London: Hayward Gallery Publishing, 2000. 
Jones, Malcolm. The Secret Middle Ages. Westport, Connecticut: Praeger, 2002.

Kelly, John. The Great Mortality: An Intimate History of the Black Death, the Most Devastating Plague of All Time. New York: Harper Collins, 2005.

Kieckhefer, Richard. Magic in the Middle Ages. Cambridge: Cambridge University Press, 1989.

Maguire, Eunice Dauterman, Henry P. Maguire, and Maggie J. Duncan-Flowers. Art and Holy Powers in the Early Christian House. Chicago: University of Illinois Press, 1989.

McDonald, Nicola, ed. Medieval Obscenities. New York: York Medieval Press, 2006.

McGuire, Brian Patrick. Jean Gerson and the Last Medieval Reformation. University Park, PA.: Pennsylvania State University Press, 2005.

McMahon, Joanne, and Jack Roberts. The Sheela-Na-Gigs of Ireland and Britain: The Divine Hag of the Christian Celts - an Illustrated Guide . Dublin: Mercier Press, 2001.

Muir, Edward. Civic Ritual in Renaissance Venice. Princeton, NJ.: Princeton University Press, 1981.

Mullett, Charles F. The Bubonic Plague and England: An Essay in the History of Preventive Medicine. Lexington, KY.: University of Kentucky Press, 1956.

Platt, Colin. King Death: The Black Death and its Aftermath in Late-Medieval England. Toronto: University of Toronto Press, 1996.

Scott, Susan, and Christopher Duncan. Return of the Black Death: The World's Greatest Serial Killer. Chichester: John Wiley \& Sons, 2004.

Sheridan, Ronald, and Anne Ross. Gargoyles and Grotesques: Paganism in the Medieval Church. Boston: New York Graphic Society, 1975.

Spencer, Brian. Pilgrim Souvenirs and Secular Badges. London: The Stationary Office, 1998.

Stone, Lee A. The Story of Phallicism. Chicago: Pascal Covici, 1927.

Sumption, Jonathan. The Age of Pilgrimage: The Medieval Journey to God. 1975. Reprint, Mahwah, NJ.: HiddenSpring, 2003.

Thomas, Keith. Religion and the Decline of Magic. New York: Charles Scribner's Sons, 1971. 
Turner, Victor. The Ritual Process: Structure and Anti-Structure. $2^{\text {nd }}$ ed. London: Aldine Transaction, 2008.

Twigg, Graham. The Black Death: A Biological Reappraisal. Berlin: Schocken Books, 1984.

Van Beuningen, H.J.E. and A.M. Koldeweij, eds. Heilig en Profaan: 1000 Laatmiddeleeuwse Insignes uit de collectie H.J.E. Van Beuningen. Cothen, Nederland: Stichting Middeleeuwse Religieuze en Profane Insignes, 1993.

Van Beuningen, H.J.E, A.M. Koldeweij and D. Kicken, eds. Heilig en Profaan 2: 1200 Laatmiddeleeuwse Insignes uit openbare particuliere collecties. Cothen, Nederland: Stichting Middeleeuwse Religieuze en Profane Insignes, 2001.

Webb, Diana. Medieval European Pilgrimage: c. 700- c. 1500. New York: Palgrave, 2002.

Williman, Daniel, ed. The Black Death: The Impact of the Fourteenth-Century Plague: Papers of the Eleventh Annual Conference of the Center for Medieval \& Early Renaissance Studies. Binghamton, NY.: Center for Medieval \& Early Renaissance Studies, 1982.

Wright, Thomas. The Worship of the Generative Powers During the Middle Ages of Western Europe. 1866. Reprinted in, Sexual Symbolism: A History of Phallic Worship Vol. II. New York: The Julian Press, 1957.

Ziegler, Philip. The Black Death. New York: The John Day Company, 1969. 


\section{CURRICULUM VITAE}

NAME: $\quad$ Lena Mackenzie Gimbel

ADDRESS: 675 North Barbee Way

Louisville, KY 40217

DOB: $\quad$ Louisville, Kentucky - October 19, 1976

EDUCATION

\& TRAINING: $\quad$ B.A., History

Magna Cum Laude

University of Louisville

2003-2010

M.A., History

University of Louisville

2010-2012

AWARDS: Filson Historical Society Internship

2011-2012

Spring 2012 Graduate Student Award

Department of History

HONORS

SOCIETIES: Phi Alpha Theta National Honors Society Golden Key International Honors Society 